\title{
Conserving Globally Rare Plants on Lands Administered by the Dillon Office of the
}

\section{Bureau of Land Management}

Prepared for the

Bureau of Land Management

Dillon Office

By

Peter Lesica

Consulting Botanist

Montana Natural Heritage Program

Natural Resource Information System

Montana State Library

December 2003

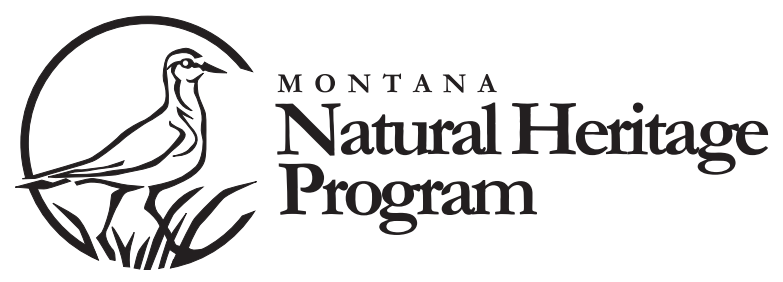




\section{Conserving Globally Rare Plants on Lands Administered by the Dillon Office of the \\ Bureau of Land Management}

Prepared for the

Bureau of Land Management

Dillon Office

Agreement Number:

ESA010009 - \#8

By

Peter Lesica

Consulting Botanist

Montana Natural Heritage Program
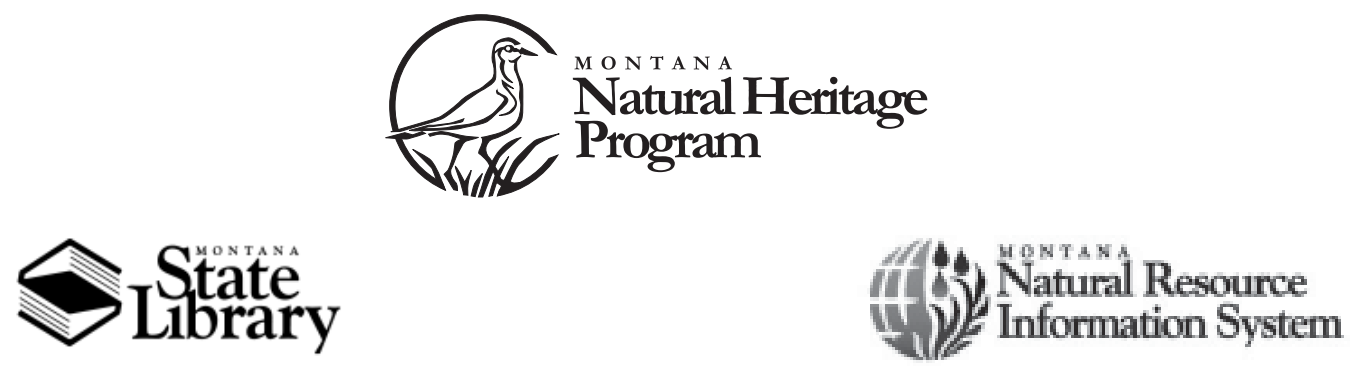

(c) 2003 Montana Natural Heritage Program

P.O. Box 201800 • 1515 East Sixth Avenue • Helena, MT 59620-1800 • 406-444-5354 
This document should be cited as follows:

Lesica, P. 2003. Conserving Globally Rare Plants on Lands Administered by the Dillon Office of the Bureau of Land Management. Report to the USDI Bureau of Land Management, Dillon Office. Montana Natural Heritage Program, Helena, MT. 22 pp. plus appendices. 


\section{EXECUTIVE SUMMARY}

Southwest Montana has a large number of globally rare plant species, many of which occur on public lands administered by the Bureau of Land Management (BLM). Previously unsurveyed BLM lands in selected areas of Beaverhead and Madison counties were inventoried for globally rare plants on the BLM Sensitive list as well as those considered Species of Concern by the Montana Natural Heritage Program.

These surveys identified 25 new occurrences for ten globally significant plant species, including seven species currently on the BLM Sensitive or Watch List. Four globally rare species -- Cymopterus hendersonii, Draba ventosa, Eriogonum soliceps and Primula alcalina -- were discovered on BLM lands in Montana for the first time. Primula alcalina was thought to be extirpated in Montana and the metapopulation discovered in the Cabin Creek drainage is now the only known occurrence in the state. Eriogonum soliceps is being described as new to science, and has been confirmed at only one other site -- the type locality in Idaho.

Herbarium research conducted during this study confirmed that another globally rare plant Erigeron parryi, first described over 100 years ago, is a distinct species found only in southwest Montana. Five populations of this Montana endemic occur on BLM lands administered by the Dillon Office.

These surveys also yielded significant new information on Montana Species of Concern that are not globally rare. Altogether, 23 occurrences were documented for 17 state rare species. Five of these plants were documented on BLM lands in Montana for the first time: Allium parvum, Braya humilis, Erigeron asperugineus, Kobresia simpliciuscula and Pedicularis crenulata (the first record for Montana).

This new data, along with information summarized from previous studies, was used to develop or expand ecological and management profiles for globally rare plants on BLM lands administered by the Dillon Office. The results also highlighted seven landscapes of particular significance for conservation of globally rare plant resources, based on the presence of healthy populations of multiple species and high-quality plant communities. Descriptions of these areas are provided, summarizing landscape-level ecological processes and their effects on plant species of concern, as well as management recommendations for each area. Survey and research priorities for both globally rare species and significant landscapes are also identified. 


\section{ACKNOWLEDGMenTS}

Many people contributed guidance, information and support during the course of this project. Brian Hockett of the BLM Dillon Office helped plan the study and gave advice on logistics. Roxanne Falise, of the BLM State Office, secured a grant from the National Fish \& Wildlife Foundation that provided major support for the work. Tulli Kerstetter and Matt Lavin provided consultation on Erigeron parryi, as did Ron Hartman on Cymopterus hendersonii and James Reveal on Eriogonum soliceps. Curtis Bjork assisted with field survey work in 2003 and with taxonomic determinations of Cymopterus hendersonii and Eriogonum soliceps. Gilbert
Little, Paul Hansen and Bear Creek Ranch graciously provided access to private property. Several current and former staff of the Montana Natural Heritage Program also made important contributions to this project. Bonnie Heidel developed the initial project proposal, and Catherine Jean assisted with selection of survey sites and provided early coordination. Sue Crispin coordinated project completion, including editing and production of the final report, and Greg Kudray assisted with final editing and proofreading. Coburn Currier attended to the many details involved in final layout and production of the report. 


\section{TABLe of Contents}

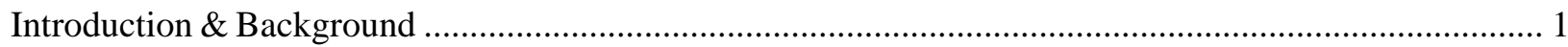

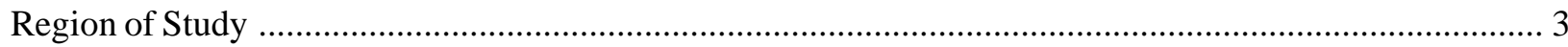

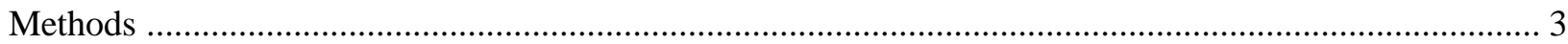

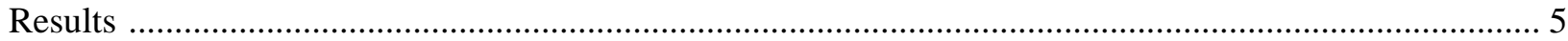

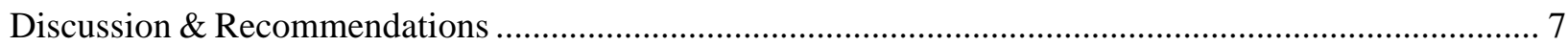

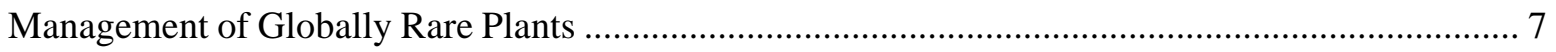

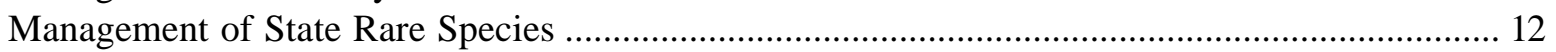

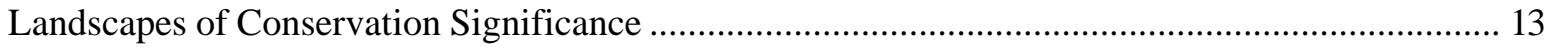

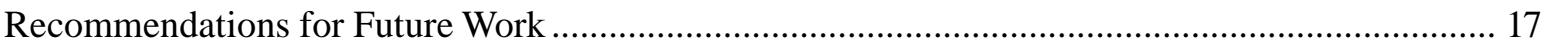

Literature Cited (includes references cited in Appendix A, B and C) ................................................... 18

Appendix A. Global / State Rank Definitions

Appendix B. Globally Rare Species Accounts

Appendix C. Landscapes of Conservation Significance - Detailed Descriptions

Appendix D. Locations of areas surveyed

Appendix E. Draft manuscript on the taxonomic status of Erigeron parryi

\section{LIST OF TABLES}

Table 1. Areas surveyed for globally rare Species of Concern ............................................................ 4

Table 2. Globally rare Species of Concern targeted for survey ................................................................. 4

Table 3. New occurrences of globally rare Species of Concern identified during this study ..................... 5

Table 4. New occurrences of state rare Species of Concern identified during this study ......................... 6

Table 5. State Species of Concern in wetland and riparian habitats ....................................................... 12

\section{LiST OF FiguRES}

Figure 1. Rare Plant Surveys, Beaverhead and Madison Counties ..................................................... 2 


\section{INTRODUCTION \& BACKGROUND}

Southwest Montana has a greater number of endemic and globally rare vascular plant species than any other part of the state (Lesica et al. 1984, Montana Natural Heritage Program 2003). A large proportion of these species occur at mid-elevations and are found on public lands administered by the Bureau of Land Management (BLM).

For the purposes of this study, globally rare or significant plant species are defined as those ranked G1 - G3 or T1 - T3 (for subspecies and varieties) by the network of Natural Heritage Programs and their international affiliate organization, NatureServe. Definitions of global and state ranks are provided in Appendix A. Conservation of globally significant plant Species of Concern is mandated under BLM regulations protecting special status species (BLM 1996). Effective management of rare plants requires a thorough understanding of the geographic distribution and habitat requirements of each species as well as the landscape-level processes that affect them (Falk 1992).

The purpose of this study was to locate and describe populations of globally significant plant species on lands administered by the Dillon Office of BLM and document their habitats and surrounding land use. This information together with results of earlier studies is used to identify areas with highly significant occurrences of globally rare plant species and to provide the BLM Dillon
Office with information to assist in managing these special status species and the landscapes that sustain them.

In the past, sensitive plant surveys have been conducted in many areas of southwest Montana on or adjacent to lands administered by the BLM Dillon Office. Locations of these surveys are shown in Figure 1 with symbols indicating relative size of the areas surveyed. These surveys include Bannack (Vanderhorst 1995c, Heidel and Vanderhorst 1996), Big Hole (Lesica 1994, Heidel and Vanderhorst 1996), Sage Creek (Lesica and Vanderhorst 1995, Heidel and Vanderhorst 1996), Upper Madison (Heidel and Vanderhorst 1996), Horse Prairie Creek (Vanderhorst 1995b), Tendoy Mountains (Vanderhorst and Lesica 1994, Vanderhorst 1995a) Centennial Valley (Culver 1993), and the Whitehall Valley (Lesica 1994). In addition, surveys for Carex idahoa (Lesica 1998), Penstemon lemhiensis (Shelly 1987) and Astragalus scaphoides (Lesica 1984) were conducted throughout portions of the area.

The current study spanned the field seasons of 2002 and 2003. All fieldwork was conducted by staff and contractors of the Montana Natural Heritage Program (MNHP), which serves as the state's primary repository of information on Montana's sensitive species and habitats. 


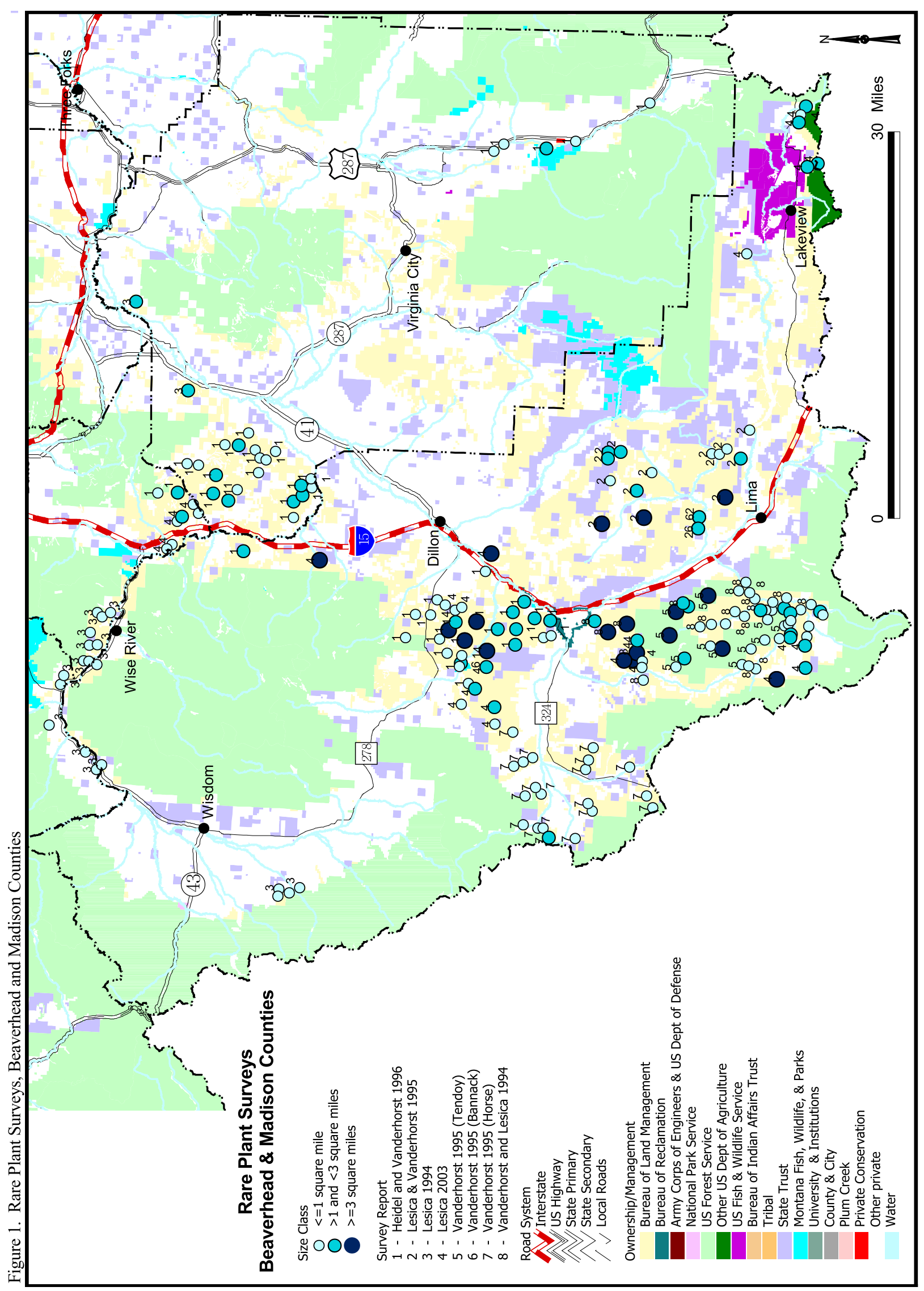




\section{Region of Study}

Southwest Montana has greater plant endemism than any other part of the state (Lesica et al. 1984). Along with adjacent Idaho and Wyoming, it has been an area of great tectonic activity and is a region of diverse soils and geologic parent materials (Perry 1962, Alt and Hyndman 1986). Edaphic diversity, lack of glaciation at low and mid elevations, and the presence of numerous mountain ranges and associated valleys are probably all responsible for the relatively large number of species that are found here and nowhere else.

This study encompasses Beaverhead and Madison counties in southwest Montana. It includes the Beaverhead, Blacktail, Centennial, Gravelly, Highland (in part), Madison (in part), Pioneer (in part), Ruby, Snowcrest and Tendoy ranges. Much of the public land managed by BLM is found in the intervening valleys of the Beaverhead, Big Hole (in part), Madison (in part), Red Rock and Ruby rivers as well as the drainages of Big Sheep, Blacktail Deer, Grasshopper, Horse Prairie, Muddy, Sage, Sagebrush and Sweetwater creeks.
Dominant vegetation of the region is sagebrush steppe at low and mid elevations with Douglas-fir forest on cool slopes and higher elevations. Highest elevations support alpine grassland and some spruce-fir forest (Cooper et al. 1995, 1997). Most of the globally rare plant species are associated with azonal lithosols or calcareous wetlands at varying elevations.

Lima, at an elevation of 6,275 feet in southern Beaverhead County, may be the climate recording station most representative of the survey areas and of significant rare plant sites. Average July maximum and January minimum temperatures were $70.8^{\circ} \mathrm{F}$ and $5.3^{\circ} \mathrm{F}$, respectively. Mean annual precipitation was 10.74 inches at Lima, with nearly 80\% falling between April and September (NOAA 1982). Precipitation generally increases from west to east in this region. Higher elevations are undoubtedly colder with greater precipitation. Average precipitation for the crests of the Tendoy and Beaverhead ranges is $30-40$ inches per year (Cooper et al. 1997).

\section{Methods}

Heritage Program Botany and Ecology staff identified large tracts of public lands administered by the Dillon Office of BLM where surveys had not previously been conducted or where previous surveys were thought to be inadequate.

Surveys were concentrated in the areas listed in Table 1. Principle survey targets include 17 globally rare species (Table 2). Surveys were conducted on foot through areas with geology, soils or hydrology considered to provide potential habitat for these plants (Nelson 1985). Locations of survey routes are documented in Appendix D. We recorded data on location, size, habitat, associated species, surrounding land use and potential threats for each population of these species that was located, as well as any other Montana Species of Concern (MNHP 2003) encountered.

The year 2002 was the third in a row that was drier than average in this part of southwest Montana. Relatively moist conditions prevailed early in the 2003 growing season, but drought conditions returned later in the summer. Drought conditions undoubtedly made it more difficult to detect plant populations because flowering was minimal for many species. This lack of flowering was probably more pronounced for annual species (e.g., Phacelia incana) compared to perennial plants, and for upland habitats compared to wetlands and riparian areas. 
Table 1. Areas surveyed for globally rare Species of Concern.

\begin{tabular}{|l|l|}
\hline Survey Sites & Date Surveyed \\
\hline Maiden Rock (5 miles northwest of Melrose) & June 2002 \\
\hline Soap Gulch-Camp Creek (east of Melrose) & June 2002 \\
\hline Pioneer Front (southwest of Melrose) & June 2002 \\
\hline Sagebrush Creek (southwest of Bannack) & June 2002 \\
\hline Grasshopper Creek (east of Bannack) & June 2002, June 2003 \\
\hline Johnson Gulch (south of Grant) & June, July 2002 \\
\hline Big Sheep Creek Basin (west of Lima) & July 2002 \\
\hline Red Rock River (Centennial Valley) & August 2002 \\
\hline East Centennial Mountains (Centennial Valley) & July, August 2002 \\
\hline Blacktail Mountains (south of Dillon) & July 2003 \\
\hline Ruby Range (south of Sheridan) & July 2003 \\
\hline North Gravelly Range (south of Virginia City) & July, August 2003 \\
\hline Upper Beaverhead River Valley & July, August 2003 \\
\hline East Highland Mountains (Silver Star) & June 2003 \\
\hline Medicine Lodge Valley (south of Grant) & July 2003 \\
\hline Snowcrest Range & August 2003 \\
\hline
\end{tabular}

Table 2. Globally rare Species of Concern targeted for survey.

\begin{tabular}{|l|l|l|}
\hline Scientific Name & Common Name & Global Rank \\
\hline Arabis fecunda & Sapphire Rockcress & G2 \\
\hline Astragalus ceramicus var. apus & Idaho Painted Milkvetch & G4T3 \\
\hline Astragalus scaphoides & Bitterroot Milkvetch & G3 \\
\hline Astragalus terminalis & Railhead Milkvetch & G3 \\
\hline Carex idahoa & Idaho Sedge & G2 \\
\hline Draba globosa & Round-fruited Draba & G3 \\
\hline Draba ventosa & Wind River Draba & G3 \\
\hline Erigeron parryi & Parry's Fleabane & GNR \\
\hline Eriogonum soliceps & Lemhi Buckwheat & G2* \\
\hline Lesquerella pulchella & Beautiful Bladderpod & G2 \\
\hline Lomatium attenuatum & Tapertip Desert-parsley & G3 \\
\hline Penstemon lemhiensis & Lemhi Beardtongue & G3 \\
\hline Phacelia incana & Hoary Phacelia & G3G4 \\
\hline Primula alcalina & Idaho Primrose & G1 \\
\hline Sphaeromeria argentea & Chicken Sage & G3G4 \\
\hline Thelypodium paniculatum & Northwestern Thelypody & G2 \\
\hline Thlaspi parviflorum & Small-flowered Pennycress & G3 \\
\hline
\end{tabular}

* Preliminary rank 


\section{Results}

Surveys in 2002 and 2003 documented 48 new or expanded occurrences of Montana Plant Species of Concern (Tables 3, 4), about half of which were for globally rare species targeted in. Twenty-eight of these new records were for plant species on Montana BLM's Sensitive or Watch lists (BLM 1996).

Four globally rare species were discovered on BLM lands in Montana for the first time during this project. Lemhi buckwheat (Eriogonum soliceps) was recently identified as new to science from a site in Lemhi County, Idaho (Reveal \& Bjork, in press). We located a second, much larger population during our surveys in the Rape Creek drainage in southern Beaverhead County, Montana. Idaho primrose (Primula alcalina) was thought to be extirpated in Montana (Heidel 2001); the metapopulation discovered during our 2002 surveys in the Cabin Creek drainage is the only known occurrence in the state.

Henderson's waferparsnip (Cymopterus hendersonii), as narrowly interpreted by Hartman (see species account in Appendix B) is found only in southwest Montana and Idaho. The Ruby
Mountain population is the third documented for Madison County. The fourth globally rare plant new to BLM lands in Montana was Wind River draba (Draba ventosa), a rare alpine species found from Alberta to Colorado and previously known in Montana from only two sites in Beaverhead and Madison counties.

This study confirmed the existence of another globally rare plant species that had been previously collected from BLM lands in Montana, but not definitively identified until now. For over 100 years Parry's fleabane (Erigeron parryi) was known only from the type collection along Grasshopper Creek in southern Beaverhead County, Montana. During the course of our study, five populations of this Montana endemic were located based on specimens housed in herbaria at the University of Montana and Montana State University. A taxonomic assessment conducted as part of this study indicates that Parry's fleabane is a distinct species (Appendix E). This brings to 18 the number of globally rare species documented from BLM lands managed by the Dillon Office.

Table 3. New occurrences of globally rare Species of Concern identified during this study (includes new populations and subpopulations).

\begin{tabular}{|l|c|c|c|}
\hline Species & BLM status & $\begin{array}{c}\text { Heritage } \\
\text { ranks }\end{array}$ & New occurrences \\
\hline Arabis fecunda & Sensitive & G2 S2 & 1 \\
\hline Astragalus scaphoides & Sensitive & G3 S2 & 2 \\
\hline Carex idahoa & Sensitive & G2 S2 & 1 \\
\hline $\begin{array}{l}\text { Cymopterus hendersonii } \\
\text { (sensu stricto) }\end{array}$ & None & GNR S2* & 1 \\
\hline Draba ventosa & None & G3 S1 & 2 \\
\hline Erigeron parryi & None & GNR S2* & 3 \\
\hline Eriogonum soliceps & None & G2 S2 & 5 \\
\hline Lesquerella pulchella & Sensitive & G2 S2 & 1 \\
\hline Lomatium attenuatum & Sensitive & G3 S2 & 4 \\
\hline Primula alcalina & Watch & G1 S1 & G3G4 S2 \\
\hline Sphaeromeria argentea & Sensitive & Gra & 2 \\
\hline
\end{tabular}

* Preliminary rank 
In addition, five species that are more widespread and common globally (G4 or G5) but rare in Montana (S1 or S2) were documented on BLM lands for the first time. Low braya (Braya humilis) is an arctic-alpine species that occurs continuously as far south as central Alberta, with disjunct locations in north central and southwest Montana, Wyoming and Colorado. One of three Montana populations and all Wyoming and Colorado populations are alpine. Simple kobresia (Kobresia simpliciuscula) also has a circumboreal distribution with disjunct populations in Montana, Wyoming and Colorado. The Cabin Creek population is the first record for southwest Montana.

Wavy-leaf lousewort (Pedicularis crenulata) is found mainly in southern Wyoming,
Colorado and adjacent Nebraska. Disjunct populations occur in Nevada and California where they are of conservation concern. The recently discovered populations along the Beaverhead River are the first recorded for Montana and are about 300 miles northwest of the nearest population in Wyoming.

Two other state rare species were newly documented on BLM lands in Montana. Small onion (Allium parvum), located at Magidan Gulch, was previously known in the state only from southern Ravalli County. Idaho fleabane (Erigeron asperugineus) is restricted to southern Idaho, adjacent Nevada and Montana, where it was previously known only from the Beaverhead Range west of Lima.

Table 4. New occurrences of state rare Species of Concern identified during this study (includes new populations and subpopulations).

\begin{tabular}{|l|c|c|c|}
\hline Species & BLM status & $\begin{array}{c}\text { Heritage } \\
\text { ranks }\end{array}$ & New occurrences \\
\hline Allium parvum & None & G5 S2 & 1 \\
\hline Aquilegia formosa & None & G5 S2 & 1 \\
\hline Braya humilis & None & G5 S1 & 1 \\
\hline Erigeron asperugineus & Watch & G4 S1 & 1 \\
\hline Eriogonum caespitosum & None & G5 S1 & 1 \\
\hline Erigeron linearis & None & G5 S1 & 1 \\
\hline Eupatorium occidentale & None & G4 S2 & 1 \\
\hline Kobresia simpliciuscula & None & G5 S2 & 1 \\
\hline Kochia americana & None & G5 S1 & 2 \\
\hline Plagiobothrys leptocladus & Watch & G4 S1 & 1 \\
\hline Pedicularis crenulata & None & G4 S1* & 1 \\
\hline Primula incana & Watch & G4G5 S2 & 2 \\
\hline Puccinellia lemmonii & None & G4 S1 & 2 \\
\hline Sphaeralcea munroana & None & G4 S1 & 1 \\
\hline Thalictrum alpinum & Sensitive & G5 S2 & 2 \\
\hline Thelypodium sagittatum & None & G4 S2 & 2 \\
\hline Viguiera multiflora & None & G4G5 S1 & 1 \\
\hline
\end{tabular}

* Preliminary rank 


\section{DiscusSion \& RECOMMENDATIONS}

\section{Management of Globally Rare Plants}

The results of our surveys suggest that many populations of globally rare plants on BLM lands in southwest Montana are relatively secure, and may benefit most from maintaining current management and land use practices. These include plants that occupy high altitude habitats, which are relatively stable and relatively little impacted by human activities, as well as some species that likely benefit from a certain level of disturbance, such as grazing, to reduce competition from surrounding vegetation. However, it should be noted that while these species currently appear to be secure, they could face future threats if management or land uses were to change significantly.

Other globally rare plant species occupy more vulnerable habitats, such as wetlands or areas at high risk for invasion of exotic weeds, and may require more active planning and management to ensure that populations survive and thrive.

Provided below is information on distribution, current status, threats and management for the 18 globally rare plant species occurring on BLM lands administered by the Dillon Office. More detailed information on identification, ecology, habitat and management considerations can be found in Appendix B. Information on all of Montana's Species of Concern is available on the MNHP website (http://nhp.nris.state.mt.us).

Sapphire rockcress (Arabis fecunda)

Current status: Heritage G2, S2; BLM Sensitive

Management comments: Sapphire rockcress is a Montana endemic that occurs only in Beaverhead, Ravalli and Silver Bow counties. There are 21 known populations of which eight are on lands administered by the Dillon BLM Office. Much of the potential habitat has been surveyed, so the majority of populations are probably known. Sapphire rockcress appears to have restrictive habitat requirements that limit its distribution. It is found in sparse vegetation on poorly developed, calcareous soil. Many sites are in close proximity to historic mining activity with associated roads.

Many populations of Sapphire rockcress in Beaverhead county are close to roads and are therefore threatened by exotic weed encroachment. Spotted knapweed (Centaurea maculosa) is spreading rapidly along roads in the County, and has been shown to reduce the reproductive success of Sapphire rockcress populations (Lesica and Shelly 1995). Continued monitoring and special management of Sapphire rockcress is warranted by its restricted distribution and significant threats from weed encroachment.

Idaho painted milkvetch (Astragalus ceramicus var. apus)

Current status: Heritage G4T3, S1; BLM Sensitive

Management comments: Idaho painted milkvetch has a small geographic range and specialized habitat requirements, being restricted to sandhills in southeastern Idaho and adjacent Beaverhead County, Montana. In Idaho it is locally common in its restricted range and habitat. In Montana it is found only in the sandhills of the Centennial Valley, where it is locally common. Idaho painted milkvetch requires sparsely vegetated sites with very sandy soils (Schassberger 1988). These early-seral habitats are maintained by a disturbance regime involving the interaction of wind, grazing and fire (Lesica and Cooper 1999).

This species' habitat could be threatened by off-road vehicle recreation, however no damage has been observed to date. More significantly, it is threatened by loss of habitat resulting from a lower frequency in the natural disturbance regime. Eastern portions of the Centennial Sandhills administered by the U.S. Fish and Wildlife Service are in late-seral condition and no longer support "sand-loving" rare species. Fire suppression and/or minimal livestock grazing could cause continued loss of early-seral habitat (Lesica and Cooper 1999).

Bitterroot milkvetch (Astragalus scaphoides)

Current status: Heritage G3, S2; BLM Sensitive

Management comments: Bitterroot milkvetch has a limited geographic range, occurring only in southern Beaverhead County, Montana and adjacent Lemhi County, Idaho. It is known from 18 sites in Montana, including the five new populations or subpopulations discovered during this study. Bitterroot milkvetch is 
most commonly found in sagebrush steppe on warm toeslopes in the foothills. Although it does not occupy much of what appears to be appropriate habitat, it is common where it does occur. This species is palatable to cattle and nearly all known populations are subject to livestock grazing, however there is no evidence that grazing has an adverse effect on population growth rates (Lesica 1995). Current management appears to be compatible with the maintenance of Bitterroot milkvetch on BLM lands.

\section{Railhead milkvetch (Astragalus terminalis)}

Current status: Heritage G3, S2; BLM Sensitive

Management comments: The range of Railhead milkvetch is limited to southern Beaverhead and Madison counties, Montana and adjacent northwest Wyoming and east-central Idaho. There are 14 known populations in the drainages of the Beaverhead and Madison rivers; no new occurrences were found during this study. Railhead milkvetch appears to have a relatively broad ecological amplitude, and has been found in many different habitats including grasslands, sagebrush steppe and subalpine meadows. Several populations are quite large.

Nearly all known populations are subject to livestock grazing. There is evidence that railhead milkvetch is palatable (Heidel and Vanderhorst 1996), but it is not known whether grazing has an adverse effect on population viability. One survey prior to this project found a population thriving on lightly to moderately grazed range, but absent from an adjacent heavily grazed area. Spotted knapweed (Centaurea maculosa) occurs along roads in the Madison Valley and has the potential to invade the gravelly, calcareous soils and displace railhead milkvetch (Heidel and Vanderhorst 1996). Threat from weed invasion has been documented for two populations on BLM lands, and may exist at others.

\section{Idaho sedge (Carex idahoa) \\ Current status: Heritage G2, S2; BLM Sensitive \\ Management comments: Idaho sedge is found in southwest Montana and adjacent southeastern Idaho.} Recently it has also been found in Oregon, northern California and Utah (Murray 2002). It is known from over 30 sites in Montana, two of which were found during this study. Many known populations are of small extent; however, there are likely many unsurveyed populations on private land. Idaho sedge occurs in moist meadows associated with streams and springs, often in ecotonal areas between wetlands and upland grassland or steppe (Lesica 1998). Most Montana occurrences are above $6000 \mathrm{ft}$. (1825 m) in elevation. Better information is needed on the abundance and threats in other states.

The riparian habitat of Idaho sedge is vulnerable to degradation from livestock grazing, agriculture, exotic weeds and road construction. Idaho sedge is palatable to livestock (Hermann 1970), and its riparian meadow habitat attracts livestock and is often severely grazed. Most leaves of the plant are near the base, so grazing reduces seed set but probably has only a small effect on vegetative vigor. However, livestock grazing results in increased abundance of Kentucky bluegrass (Poa pratensis, Hansen et al. 1995), an aggressive exotic grass that may compete with Idaho sedge. Overgrazing can also result in bank destabilization followed by erosion, stream downcutting and eventual lowering of the water table (Kauffman and Krueger 1984, Belsky et al. 1999). Riparian areas are often used for hay production, and populations of Idaho sedge on private land may be lost when these areas are mowed, irrigated or seeded to exotic hay grasses. Idaho sedge habitat may also be lost when roads are constructed in riparian corridors.

Henderson's waferparsnip (Cymopterus hendersonii, sensu stricto)

Current status: Heritage GNR, S2 (preliminary state rank); BLM none

Management comments: Henderson's waferparsnip, in the narrow sense, is known only from southwest Montana and adjacent east-central Idaho. (See Appendix C for a discussion of this species' taxonomy.) In Montana it is documented from four sites in Ravalli County and three in Madison County. Henderson's waferparsnip is found in sparsely vegetated, stony soil near or above treeline. These high-elevation sites are often in wilderness areas and do not appear to be currently at risk. This species appears to be rare throughout its limited range, but may be more common than records indicate, as thorough surveys of high-elevation habitats have not been done, and there could be many undiscovered populations in remote areas. 
Round-fruited draba (Draba globosa)

Current status: Heritage G3, S1; BLM Watch

Management comments: Round-fruited draba occurs in scattered locations in the Rocky Mountains from southwest Montana to central Colorado. It is found in sparsely vegetated, stony, calcareous soil near or above treeline. In Montana, it is documented from four sites in Beaverhead and Madison counties, only one of which is on BLM lands. This plant is inconspicuous and similar to many other species of Draba, so it is likely that undiscovered populations exist. Its high-elevation habitats do not appear to be threatened, and current management appears adequate to sustain this plant. At least two Montana sites lie within Wilderness or Research Natural Areas on Forest Service lands. The Heritage rank may be considered for revision to S2 because of the lack of documented threats.

Wind River draba (Draba ventosa)

Current status: Heritage G3, S1; BLM none

Management comments: Wind River draba occurs from southwest Montana to Colorado and Utah, and appears to be rare throughout much of its range. In Montana it is known from four locations in the Madison, Pioneer, Tobacco Root and Snowcrest ranges of Beaverhead and Madison counties. It is found on talus slopes near or above treeline. These high-elevation habitats are relatively inaccessible and do not appear to be threatened. The Heritage rank may be considered for revision to S2 because of the lack of documented threats.

\section{Parry's fleabane (Erigeron parryi)}

Current status: Heritage GNR, S2 (preliminary state rank); BLM none

Management comments: Parry's fleabane was described 100 years ago but until recently has been known only from the type collection made along Grasshopper Creek in Beaverhead County, Montana. Recent surveys indicate that this species occurs in scattered locations in Beaverhead, Madison, Broadwater and Jefferson counties (See Appendix E). It is currently known from at least six localities. Parry's fleabane is found on sparsely vegetated, skeletal, limestone-derived soils of exposed gentle slopes and ridge crests.

Current management appears to be appropriate for this species. All known populations are subject to livestock grazing, however the plant is probably not palatable and likely benefits from disturbance that reduces the dominant vegetation. Two of the known populations (Grasshopper Creek, Silver Star) are in historic mining districts. Disturbances associated with mining activity may have degraded populations in the past and pose potential future threats. Further survey work is needed to determine if additional populations exist.

\section{Lemhi buckwheat (Eriogonum soliceps)}

Current status: Heritage (preliminary ranks) G2, S2; BLM none

Management comments: Lemhi buckwheat is a newly described species (Reveal and Bjork, in press) known from only two recently surveyed locations, one in southern Beaverhead County, Montana and the other in adjacent Lemhi County, Idaho. Herbarium specimens that appear to be this species also exist from about 10 other localities in Beaverhead, Madison and Deerlodge counties, Montana. The surveyed Beaverhead County population is estimated to have more than 15,000 plants and occupies sparsely vegetated slopes with calcareous clay soils.

Both of the recently surveyed populations of Lemhi buckwheat are subject to livestock grazing, but the sparsely vegetated slopes probably receive little impact from cattle. The barren slope habitat could potentially be impacted by ATV recreation. Further surveys are needed to determine the full range of this species in Montana as well as the status of historically documented populations and any threats or management needs.

\section{Beautiful bladderpod (Lesquerella pulchella)}

Current status: Heritage G2, S2; BLM Sensitive

Management comments: Beautiful bladderpod is known rangewide from 14 localities, all in Beaverhead County, Montana. It is found on sparsely vegetated, stony, calcareous soil in the foothills to above treeline in the Pioneer and Centennial mountain ranges. Many of the known populations are in historic mining districts with numerous primitive roads. Renewed mining activity, off-road vehicle recreation and exotic weed invasion could pose risks to these populations. 
Taper-tip desert-parsley (Lomatium attenuatum)

Current Status: Heritage G3, S2; BLM Sensitive

Management comments: Taper-tip desert-parsley occurs only in Beaverhead and Madison counties, Montana and adjacent Park County, Wyoming. There are 11 known populations in Montana (five of which were added or expanded through this study), and many populations are large in numbers and extent. It grows in sparsely vegetated, stony calcareous soil from the foothills to near or above treeline, and occurs in all southwest Montana mountain ranges west of the Madison River where limestone is present. Some populations of tapertip desert-parsley occur in historic mining districts with numerous primitive roads.

Current management appears to be compatible with this plant's requirements. Most low-elevation populations of taper-tip desert parsley are subject to livestock grazing, but cattle generally don't impact its steep, barren habitat, and the plant is most likely unpalatable. However, renewed mining activity, off-road vehicle recreation and exotic weed invasion could pose future risks. There are currently no known anthropogenic threats to the high-elevation populations.

Lemhi beardtongue (Penstemon lemhiensis)

Current status: Heritage G3, S2; BLM Sensitive

Management comments: Lemhi beardtongue is endemic to Beaverhead, Deer Lodge, Ravalli and Silver Bow counties, Montana and adjacent Lemhi County, Idaho. There are more than 50 recorded populations in Montana, but most are small, and some have proven ephemeral or have been extirpated; in addition, new populations continue to be found. Lemhi beardtongue usually occurs in a matrix of sagebrush steppe but often is found in sparsely vegetated microsites such as steep slopes or road banks. Many species of Penstemon occur in ruderal habitats and may have naturally short-lived populations. Studies suggest that Lemhi penstemon benefits from fire, possibly by reducing plant cover and encouraging germination and establishment (Heidel and Shelly 2001).

The exotic spotted knapweed (Centaurea maculosa) is invading along roads throughout much of southwest Montana and may threaten roadside populations. Fire suppression may also threaten the vigor of populations, because it can result in lower reproductive rates. Several populations occur in historic mining districts with numerous primitive roads. Renewed mining activity, off-road vehicle recreation and exotic weed invasion pose possible threats to these populations. This plant is vulnerable because of the small total number of individuals and potential threats to some populations. However, a global analysis of population trend for Lemhi beardtongue would be valuable because overall abundance of this ruderal species may be increasing rather than decreasing.

Hoary phacelia (Phacelia incana)

Current status: Heritage G3G4, S2; BLM Watch

Management comments: Hoary phacelia is found from central Idaho and southwest Montana, south to eastern Nevada, northern Utah and northwest Colorado. In Montana it is known from fewer than 10 sites in Beaverhead County. Hoary phacelia occurs in sparsely vegetated, often stony, limestone-derived soil of slopes in the foothills. It is most often found beneath a canopy of curl-leaved mountain mahogany (Cercocarpus ledifolius).

No threats have been identified, and current management is probably adequate to support hoary phacelia on BLM lands in Montana. Mule deer usually graze its habitat, and although livestock also have access, the steep slopes and dense, low canopy deter most cattle. Hoary phacelia is an annual, so grazing or moderate disturbance of any kind probably has a positive effect on population growth. The annual habit means that populations are difficult to detect in dry years, thus the species could be more common than records indicate. Although populations appear to be small, the annual habit also suggests that they could be much larger in years with favorable environmental conditions.

Idaho primrose (Primula alcalina)

Current status: Heritage G1, S1; BLM none

Management comments: Idaho primrose is currently known from one recently discovered occurrence in Beaverhead County, Montana and five in adjacent east-central Idaho - all with at least 10,000 plants (Elzinga 1997). A second Montana locality based on a 1936 collection is presumed extinct. Idaho primrose occurs in wet 
calcareous meadows associated with upwelling areas in the headwaters of spring-fed creeks, at higher elevations in the sagebrush steppe zone.

Idaho primrose is vulnerable because it is known from only a handful of sites in its narrow geographic range, and its habitat apparently depends on adequate moisture throughout the growing season. All populations are subject to livestock grazing, but the response of this species to grazing impacts is not fully documented. The species can be threatened by alterations to the hydrology of its riparian habitat, including diversion of upstream waters for irrigation or domestic use and lowering of the water table from upstream channel downcutting. The Montana population may be vulnerable to livestock grazing and irrigation diversion; much of that population is on private land.

Chicken Sage (Sphaeromeria argentea)

Current status: Heritage G3G4, S2; BLM Sensitive

Management comments: Chicken sage occurs in east-central Idaho and adjacent Beaverhead County, Montana, with disjunct populations in Nevada, southwest Wyoming and adjacent Colorado. There are nearly 20 known localities south of Dillon, including four new ones that were documented during this study. Many populations are sparse but spread over large areas, so estimates of population numbers are difficult. Chicken sage is most often found in stony, calcareous soil on sparsely vegetated slopes, sometimes associated with mountain mahogany (Cercocarpus ledifolius) or sagebrush (Artemisia spp.). However, it may also occur in clay soils of eroding slopes and stream terraces.

All known populations are subject to livestock grazing; however chicken sage is aromatic and most likely unpalatable to cattle. Although it is limited to a small area of the state, the habitats in which it occurs are common. No anthropogenic threats have been identified, and current management appears to be compatible with this species' ecological requirements. The Heritage rank of this species may be considered for revision to S3, based on the number and extent of known occurrences and the absence of identified threats under current land use practices.

\section{Northwestern thelypody (Thelypodium paniculatum) \\ Current status: Heritage G2, SH; BLM none \\ Management comments: Northwestern thelypody is found from southwest Montana to Colorado. For} Montana, there is one 1899 collection from Beaverhead county and a report for Madison County, so the species has not been confirmed to occur on BLM lands in the state. Northwestern thelypody occurs in meadows that are wet throughout most of the growing season. The riparian meadow habitat is often subject to heavy livestock grazing. However, the effect of grazing on Northwestern thelypody is uncertain because many species in the Mustard family respond positively to disturbance. Riparian meadows are threatened by irrigation diversions and channel degradation resulting in lowered water tables. This species should continue to be sought in appropriate habitats in southwest Montana, and the source of the Madison County report (Dorn 1984) should be sought in the Rocky Mountain Herbarium.

Small-flowered pennycress (Thlaspi parviflorum)

Current status: Heritage G3, S2; BLM none

Management comments: Small-flowered pennycress is known from sixteen localities in five southwest Montana counties, and also occurs in adjacent northwest Wyoming and east-central Idaho. It is found in mesic grasslands, turf and sagebrush steppe communities at mid and high elevations. Few populations documented have been large. It is a small, short-lived species that grows and flowers early in the season before being overtopped by taller vegetation. Most of the habitat of small-flowered pennycress is subject to livestock grazing, however grazing that reduces the cover of dominant plants is likely to favor this diminutive species. Fire probably also creates habitat for small-flowered pennycress, and population growth could be retarded by fire suppression. 


\section{Management of State Rare Species}

In addition to the 18 globally rare species listed above, BLM lands administered by the Dillon Office provide important habitat for 12 plant species documented on or near BLM lands that are

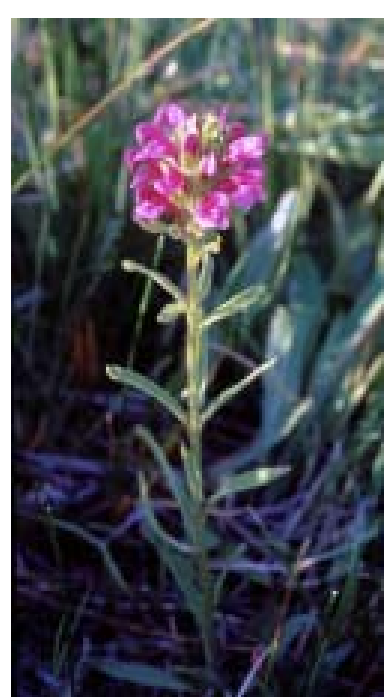

Pedicularis crenulata, Beaverhead Co. not at risk globally, but are rare and especially vulnerable in Montana because they occupy wetland or riparian habitats. These species are listed in Table 5, along with Spiranthes diluvialis, a globally rare wetland plant that has good potential to occur on BLM lands.

The newly discovered Montana populations of Pedicularis crenulata are disjunct from the main range in southern
Wyoming and

Colorado. Braya

humilis and

Kobresia

simpliciuscula are widespread in arctic and boreal regions, but Montana populations are widely separated and disjunct from the primary range. These disjunct populations are likely to have unique genetic material that

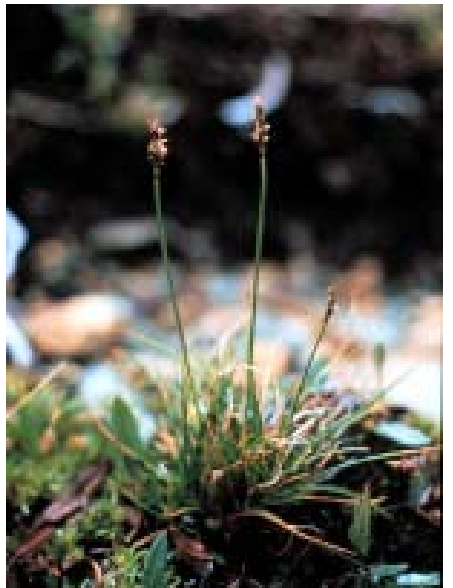

Kobresia simpliciuscula, Reynolds Peak, Glacier National Park is of conservation significance (Lesica and Allendorf 1995). All of these wetland and riparian species, especially the disjunct species, warrant special management attention because their habitat is especially prone to anthropogenic degradation.

Table 5. State Species of Concern in wetland and riparian habitats.

\begin{tabular}{|l|l|c|c|}
\hline Scientific Name & Common Name & $\begin{array}{c}\text { Heritage } \\
\text { Ranks }\end{array}$ & $\begin{array}{c}\text { Current BLM } \\
\text { Status }\end{array}$ \\
\hline Atriplex truncata & Wedge-leaved saltbush & G5 S1 & Watch \\
\hline Braya humilis & Low braya & G5 S1 & None \\
\hline Downingia laeta & Great Basin downingia & G5 S1 & Watch \\
\hline Elodea longivaginata & Long sheath waterweed & G4G5 S2 & Watch \\
\hline Hutchinsia procumbens & Hutchinsia & G5 S1 & Watch \\
\hline Kobresia simpliciuscula & Simple kobresia & G5 S2 & None \\
\hline Lomatogonium rotatum & Felwort & G5 S1 & Watch \\
\hline Pedicularis crenulata & Purple lousewort & G4 S1 & None \\
\hline Primula incana & Mealy primrose & G4G5 S2 & Watch \\
\hline Puccinellia lemmonii & Lemmon’s alkaliagrass & G4 S1 & None \\
\hline Spiranthes diluvialis & Ute Ladies' tresses & G2 S2 & Watch \\
\hline Taraxacum eriophorum & Rocky Mountain dandelion & G4 S2 & Sensitive \\
\hline Thalictrum alpinum & Alpine meadowrue & G5 S2 & Sensitive \\
\hline
\end{tabular}




\section{Landscapes of Conservation Significance}

Effective conservation of plant species usually requires not only protection of the immediate area where the species occurs, but effective management of the larger landscape in order to maintain ecological processes at varying scales that are essential to maintaining its habitat. In addition, occurrences of rare plant species are useful for identifying landscapes of conservation significance for several reasons.

First, globally rare species occur only in a restricted range, often with a relatively small number of populations. Each population is important because the loss of even one may significantly increase the likelihood of global extinction. Furthermore, many phytophagous invertebrates depend on one or a small handful of plant species for survival. Thus, many rare invertebrates likely depend on rare plants, so a site with many rare plants is likely to support other, less conspicuous rare species as well (Crisp et al. 1998, Panzer and Schwartz 1998, Reid 1998). Finally, populations of plants on the edge of their range (state rare) may often harbor genetic information not present in the main part of the species range (Lesica and Allendorf 1995).

Seven landscapes that represent important "hotspots” of global and state rare plant species

Big Sheep Creek Basin is a high valley between the Beaverhead and Tendoy mountain ranges in southern Beaverhead County. The area encompasses metapopulations of three globally rare species: Carex idahoa, Primula alcalina and Thlaspi parviflorum. The former two species are associated with wetlands. The Carex idahoa metapopulation in Big Sheep Creek Basin is one of the largest if not the largest in Montana. The Primula alcalina population is the only one known in Montana and one of fewer than ten globally. Kobresia simpliciuscula is common in boreal regions but rare in the Continental U.S. An additional six species that are rare in Montana but widespread and more common elsewhere also occur in these wetlands. Eight Plant Species of Concern are found in upland or riparian habitats in Big Sheep Creek Basin. Low sagebrush communities, Artemisia arbuscula/Agropyron spicatum, richness were identified on BLM lands administered by the Dillon Office based on information from surveys and herbarium records. They are Big Sheep Creek Basin, Centennial Sandhills, East Centennial Mountains, Grasshopper Creek, Johnson Gulch and Rape Creek. Six of these areas encompass one or more of the largest populations of several rare plants in a habitat with little history of anthropogenic degradation. They rarely represent the only good-quality occurrence of any species, but are particularly valuable because of the large number of rare species in a relatively small area. Two areas have excellent examples of rare plant communities or high quality stands of communities that are at risk of future degradation (Brownes Gulch, Centennial Sandhills), and most also support common vegetation communities of good quality and condition.

Brief descriptions of these seven areas follow. Appendix C provides more detailed descriptions, including maps showing the location and general extent (precise boundaries were not delineated), and important management considerations.

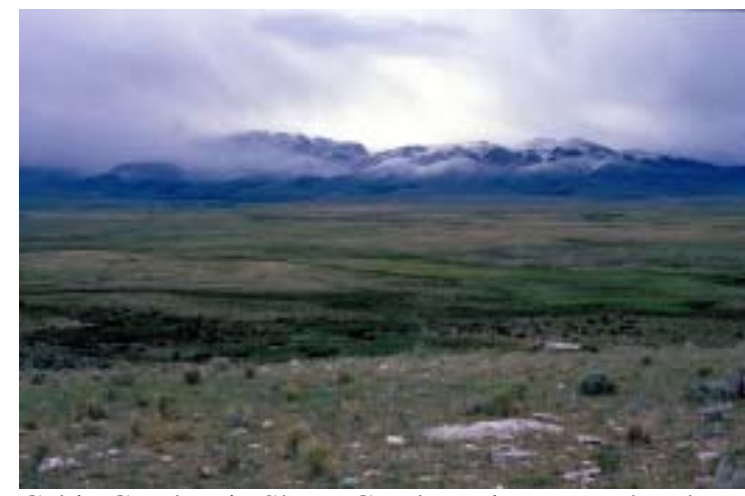

Cabin Creek, Big Sheep Creek Basin, Beaverhead Co.

Artemisia longiloba/Agropyron smithii and Artemisia longiloba/Festuca idahoensis are rare in Montana, found only in Beaverhead County. The latter two community types are globally rare. 
Brownes Gulch lies in the eastern foothills of the East Pioneer Mountains in northern Beaverhead County. The wetland and riparian plant communities provide the primary conservation significance of this area, which also encompasses extensive aspen woodlands and wetland vegetation associated with springs in the western portion. There is a healthy cottonwooddominated riparian area $n$ the southern part of the area and several stands of basin big sagebrush occur along intermittent streams in the eastern half. There is only one Plant Species of Concern known to occur in the Brownes Gulch area: Kochia americana. It is known from fewer than five locations in Montana but is more common elsewhere.

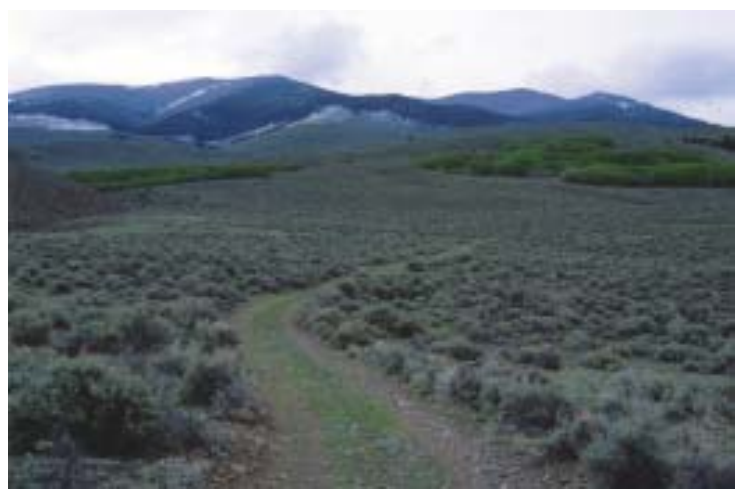

Seven Springs, Brownes Gulch, Beaverhead Co.
Centennial Sandhills lie on the north side of Red Rock Lake in the northeast corner of the Centennial Valley, a broad trough at the head of the Red Rock River. The azonal, sandy soils of the sandhills support unusual vegetation and encompasses the only Montana populations of globally rare Astragalus ceramicus var. apus. This plant occurs only in the Centennial Sandhills and the sandhills of southeastern Idaho. Elymus flavescens and Cryptantha fendleri, two other species found at the site, are more widespread globally but are rare in Montana. The Centennial Sandhills is the only Montana location for Elymus flavescens.

The Centennial Sandhills are the highest sandhills area in Montana and the Northern Rocky Mountains and is the only Montana location for two plant communities, the Crysothamnus viscidiflorus/Stipa comata and Artemisia tridentata tridentata/Stipa comata community types. The area also provides habitat for two animal species of concern: Preble's shrew and the Great Basin pocket mouse (Hendricks and Roedel 2002). Without special management, many of the biological values of this unique site could be lost.

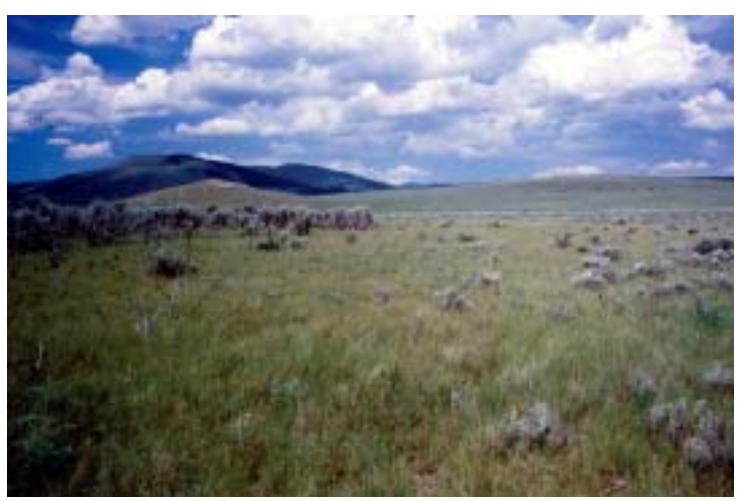

Centennial Sandhills, Beaverhead Co. 
The East Centennial Mountains are part of an east-west trending range that forms the border between Montana and Idaho in southern Beaverhead County. The area is virtually roadless. The East Centennial Mountains support populations of three globally rare species (G2-G3) that occur primarily in southwest Montana and adjacent Idaho and/or Wyoming: Astragalus terminalis, Draba globosa, and Lesquerella pulchella. The East Centennial Mountains also encompass populations of seven plant species with a wider global distribution but considered rare in Montana. Aquilegia formosa, Balsamorhiza macrophylla, Carex multicostata, Haplopappus nanus, Penstemon whippleanus Stellaria jamesiana and Viguiera multiflora each have fewer than five known occurrences in Montana. Astragalus terminalis, Lesquerella pulchella and

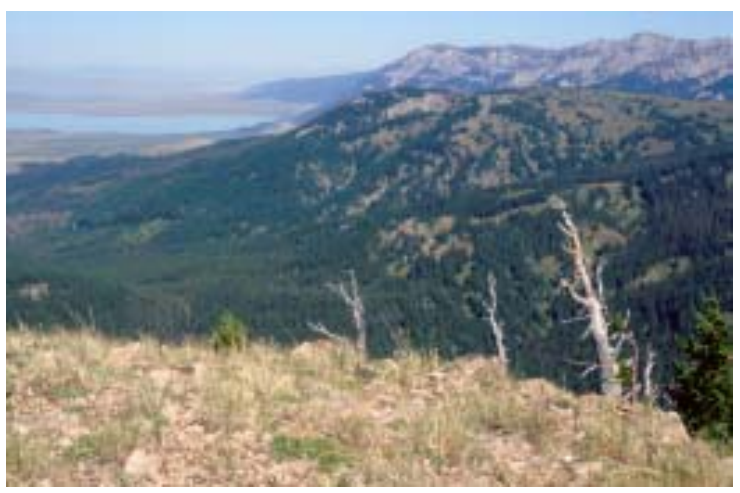

Nemesis Mountain, Beaverhead Co.

Penstemon whippleanus are listed as sensitive by BLM. Balsamorhiza macrophylla, Carex multicostata and Draba globosa are on the BLM watch list.
Grasshopper Creek encompasses the geologically diverse southern spur of the Pioneer Range in central Beaverhead County. The site includes the drainage of lower Grasshopper Creek Canyon between Bannack and the confluence with the Beaverhead River. It has one of the highest concentrations of endemic plants in southwest

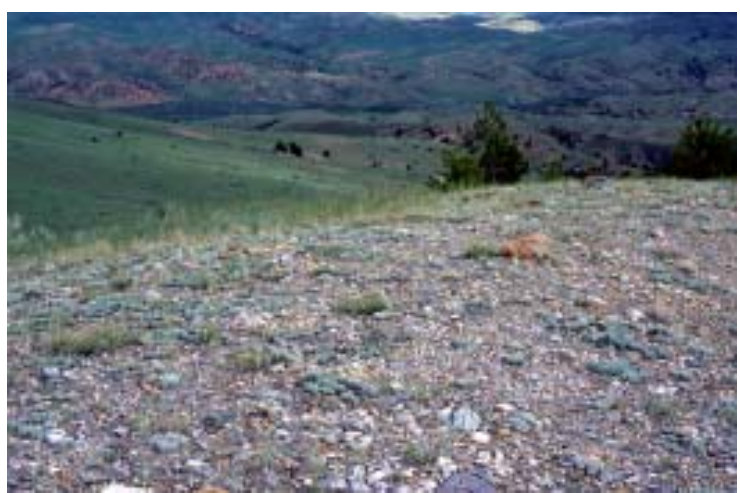

Grasshopper Creek, Beaverhead Co.
Montana, and encompasses metapopulations of five globally rare species (G1-G3) that occur only in southwest Montana and adjacent Idaho and/or Wyoming: Astragalus scaphoides, Astragalus terminalis, Lesquerella pulchella, Lomatium attenuatum and Penstemon lemhiensis. This area supports Montana's largest metapopulations of three of these regional endemics: A. scaphoides, $L$. pulchella and $L$. attenuatum. In addition, there is a large population of Erigeron parryi. This area also encompasses populations of three plant species with a wider global distribution but considered rare in Montana: Allium parvum, Sphaeromeria argentea and Taraxacum eriophorum; seven of these are listed as sensitive by BLM: Astragalus scaphoides, Astragalus terminalis, Lesquerella puchella, Lomatium attenuatum, Penstemon lemhiensis, Sphaeromeria argentea and Taraxacum eriophorum. 
Johnson Gulch lies on the west side of the Tendoy Range in southern Beaverhead County. It includes Poison Lakes, two small (ca. 5 acres) natural water bodies just west of the Tendoy crest at 8,100-8,300 ft. in elevation. The upper lake has a broad drawdown zone and appears to be fed primarily by snowmelt and other surface runoff. The lower lake has a stable water level and must be fed by underground springs, possibly originating at the upper lake. The lower lake has a broad band of floating peat separating the shore from open water.

Johnson Gulch has a high concentration of endemic plants, encompassing metapopulations of five globally rare species (G1-G3) that occur only in southwest Montana and adjacent Idaho and/or Wyoming: Astragalus scaphoides, Carex idahoensis, Lomatium attenuatum, Penstemon lemhiensis, and Thlaspi parviflorum. It also supports the state's second largest metapopulation of Lomatium attenuatum. However, populations of Astragalus scaphoides, Carex parryana ssp. idahoa, Penstemon lemhiensis and Thlaspi parviflorum are relatively small. Johnson Gulch encompasses populations of three plant species with a wider global distribution but considered rare in Montana: Draba densifolia, Kochia americana and Phacelia incana. Four of the globally rare

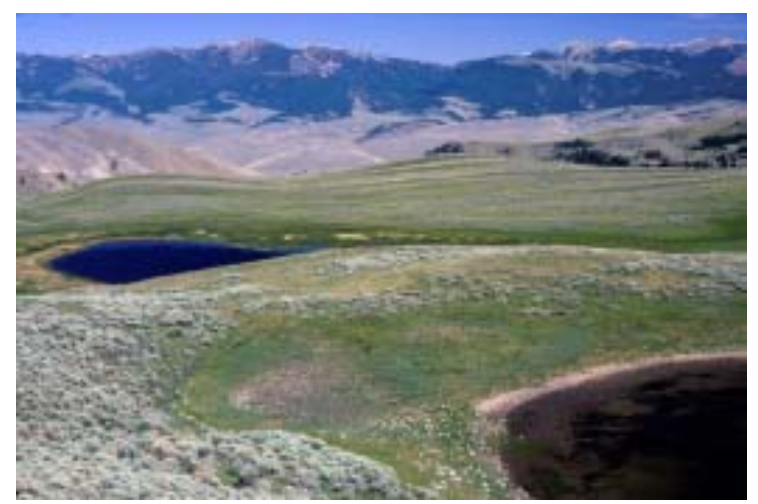

Poison Lakes, Johnson Gulch, Beaverhead Co.

species are listed as Sensitive by BLM, and Phacelia incana is on the Watch List.

Lower Poison Lake is noteworthy for being one of the highest fens (8,100 ft.) in Montana. Although the vascular vegetation is species poor, this unusual fen may harbor rare invertebrates or ecotypes of common species. Small examples of low sagebrush communities dominated by Artemisia arbuscula occur in this site; they are uncommon in Montana and restricted to southern Beaverhead County.
Rape Creek consists almost entirely of low, rounded hills and broad ridges interspersed with local outcrops of ashy shale slopes and Challis Volcanics. The newly discovered Eriogonum soliceps appears to be endemic to Beaverhead and

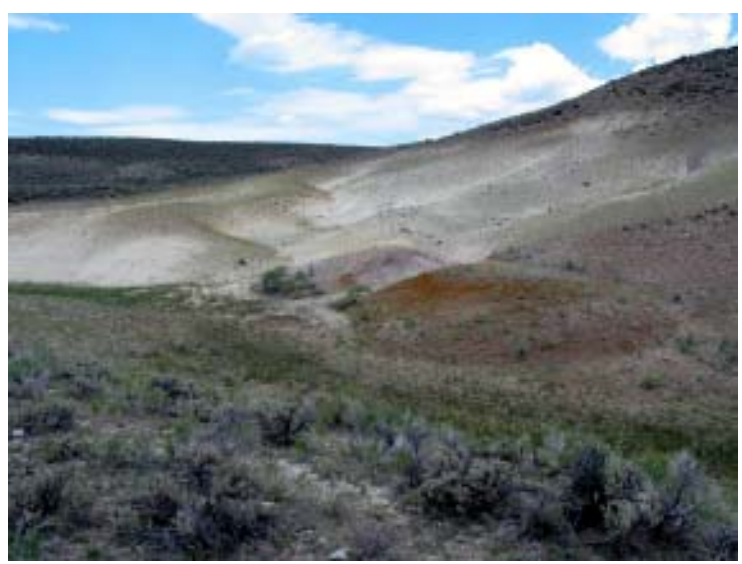

Rape Creek, Beaverhead Co. (perhaps) Madison counties, Montana and adjacent Lemhi County, Idaho. It is currently known from only two sites, although there is indication that others exist. The Rape Creek population is the largest known population. Three other Species of Concern occur within the Rape Creek study site, none of which are regional endemics.

Plagiobothrys leptocladus is common in limited areas of the western Great Basin and Columbia Basin, but is rare and scattered elsewhere.

Puccinellia lemmonii is found mostly in the Great Basin and is scattered elsewhere in the West. It is rare except in small portions of its range.

Sphaeromeria argentea is distributed in three widely separated centers in the Rocky Mountains and Great Basin, and is not common anywhere in its range. The small wetlands encountered, particularly the alkali spring in section 19, and alkali flats along intermittent creeks, are in good condition, having almost exclusively native species. 


\section{Recommendations for Future Work}

Lemhi buckwheat (Eriogonum soliceps) is a newly described species. Only one population has been fully surveyed and mapped, and several others have been tentatively identified from herbarium specimens. These localities - and other appropriate habitats in Beaverhead and Madison counties - should be surveyed to determine the distribution and population status of this species in Montana and to identify any threats.

More accurate mapping of colonies of wavy-leaf lousewort (Pedicularis crenulata) on BLM lands along the Beaverhead River would help prevent loss of this rare plant in the event of wildlife habitat enhancement projects.

There are no recent observations of Northwestern thelypody (Thelypodium paniculatum) from Montana. Dorn (1984) reports this plant from Madison Co., perhaps based on a specimen at the University of Wyoming Herbarium. Surveys based on this report may result in location of Montana populations.

The taxonomic status of Idaho eveningprimrose (Oenothera pallida var. idahoensis) is uncertain. The most recent monograph (Munz 1931) describes it as a valid local endemic variety. However, Patricia Packard, a taxonomist at College of Idaho, does not believe it is worthy of recognition. It is not known what evidence exists to support this position. A small taxonomic study and consultation with Warren L. Wagner
(Smithsonian Institute) may shed light on this problem.

The global conservation status of Idaho sedge (Carex idahoa) should be re-evaluated in light of collections from Oregon, Utah and California reported in the Flora of North America. Currently we do not know the status of populations in these states and whether it is rare and threatened there.

There are seven known locations for Parry's fleabane (Erigeron parryi); however, only one population has been fully mapped, because of mixed private and public ownership and the fact that its status as a globally significant species has just been clarified. Further surveys for new populations and better surveys of Grasshopper Creek, Ruby Reservoir, Muddy Creek and Red Butte sites would allow better assessment of the plant's conservation status and management needs. Conservation of biological diversity on lands administered by the BLM Dillon Office would also be well served by surveys and habitat assessments of wetland and riparian species that are rare in Montana, though not globally at risk. These plants occur in habitats more likely to be degraded by land uses and management actions. Twelve such species are found on or near lands administered by the Dillon Office, and were listed in the Discussion section of this report. 


\section{Literature Cited}

Achuff, P. L. 1992. Demographic monitoring of Penstemon lemhiensis. Unpublished report for the Bureau of Land Management. Montana Natural Heritage Program, Helena, MT. 11 pp.

Al-Shehbaz, I. A. 1973. The biosystematics of the genus Thelypodium (Cruciferae). Contributions from the Gray Herbarium No. 204:3-148.

Alt, D. and D. W. Hyndman. 1986. Roadside geology of Montana. Mountain Press, Missoula, MT.

Arno, S. F. and G. E. Gruell. 1983. Fire history at the forest-grassland ecotone in southwestern Montana. Journal of Range Management 36: 332-336.

Barneby, R.C. 1989. Fabales. In A. Cronquist, A.H. Holmgren, N.H. Holmgren, J.L. Reveal, and P.K. Holmgren (eds.). Intermountain flora: Vascular plants of the Intermountain West, U.S.A. Vol. 3, Part B. New York Botanical Garden, Bronx. 279 pp.

Belsky, A. J., A. Matzke and S. Uselman. 1999. Survey of livestock influences on stream and riparian ecosystems in the western United States. Journal of Soil and Water Conservation 54: 419-431.

Bureau of Land Management. 1996. BLM 6840 Manual Supplement- Special Species Management. Montana State Office, Billings.

Cooper, S. V., P. Lesica, R. L. DeVelice, and J. T. McGarvey. 1995. Classification of southwestern Montana plant communities with emphasis on those of Dillon Resource Area, Bureau of Land Management. Montana Natural Heritage Program, Helena.
Cooper, S. V., P. Lesica and D. Page-Dumroese. 1997. Plant community classification for alpine vegetation on the Beaverhead National Forest, Montana. USDA Forest Service General Technical Report INTGTR-362, Ogden, UT.

Coulter, J. M. and J. Rose. 1900. Contributions to the U.S. National Herbarium 7: 190.

Crisp, P. N., K. J. M. Dickinson and G. W. Gibbs. 1998. Does native invertebrate diversity reflect native plant diversity? A case study from New Zealand and implications for conservation. Biological Conservation 83: 209-220.

Cronquist, A. 1947. Revision of the North American species of Erigeron, north of Mexico. Brittonia 6: 121-302.

Cronquist, A. 1955. Vascular plants of the Pacific Northwest, Part 5: Compositae. University of Washington Press, Seattle.

Cronquist, A. 1961. Umbelliferae Pages 506-586 in C. L. Hitchcock et al., Vascular Plants of the Pacific Northwest, Part 3. University of Washington Press, Seattle.

Culver, D. R. 1993. Sensitive plant species inventory in the Centennial Valley, Beaverhead County, Montana. Montana Natural Heritage Program, Helena, MT.

Dorn, R. D. 1984. Vascular plants of Montana. Mountain West Publishing, Cheyenne, WY.

Elzinga, C. 1997. Habitat conservation assessment and strategy for the alkaline primrose (Primula alcalina). Idaho State Conservation Effort, Idaho Conservation Data Center, Boise. 
Falk, D. A. 1992. From conservation biology to conservation practice: strategies for protecting plant diversity. Pages 397-432 in P. L. Fiedler and S. K. Jain (editors), Conservation Biology. Chapman and Hall, London.

Haines, A. L. (ed.). 1955. Osborne Russell's journal of a trapper. Oregon Historical Society and Champoeg Press, Portland.

Hartman, Ronald. Personal communcation. University of Wyoming Herbarium, Laramie, WY.

Hansen, P., Pfister, R., Boggs, K., Cook, B.J., Joy, J., Hinkley, D.K. 1995. Classification and management of Montana's riparian and wetland sites. Montana Forest and Conservation Experiment Station Miscellaneous Publication 54, Missoula.

Heidel B. 2001. Plant species of concern. Montana Natural Heritage Program, Helena, MT.

Heidel, B. L. and J. S. Shelly. 2001. The effects of fire on Lemhi penstemon (Penstemon lemhiensis)- final monitoring report, 19952000. Montana Natural Heritage Program, Helena, MT.

Heidel, B. L. and J. S. Shelly. 1997. The effects of fire on Penstemon lemhiensis - monitoring establishment report, 1995 and 1996. Unpublished report to the Beaverhead National Forest and the Bureau of Land Management. Montana Natural Heritage Program, Helena, Montana. 11 pp. plus appendices.

Heidel, B. L. and J. Vanderhorst. 1996. Sensitive plant species surveys: Butte District, Beaverhead and Madison Counties, Montana. Montana Natural Heritage Program, Helena, MT.
Hendricks, P. and M. Roedel. 2002. Preble's shrew and Great Basin pocket mouse from the Centennial Valley Sandhills of Montana. Northwestern Naturalist 83: 31-34.

Hermann, F. J. 1970. Manual of carices of the Rocky Mountains and Colorado Basin. USDA Forest Service Agriculture Handbook 374, Washington D.C.

Kauffman, J.B., Krueger, W.C. 1984. Livestock impacts on riparian ecosystems and streamside management implications... a review. Journal of Range Management, 37, 430-437.

Lesica, P. 1984. Report on the conservation status of Astragalus scaphoides, a candidate threatened species. The Nature Conservancy, Helena, MT.

Lesica, P. 1993. Report on the conservation status of Arabis fecunda, a candidate threatened species. Report to the U.S. Fish and Wildlife Service. Montana Natural Heritage Program, Helena. 52 pp.

Lesica, P. 1994. Sensitive plant survey of BLM lands along the Big Hole River and in the Whitehall Valley. Montana Natural Heritage Program, Helena, MT.

Lesica, P. 1995. Demography of Astragalus scaphoides and effects of herbivory on population growth. Great Basin Naturalist 55: 142-150.

Lesica, P. 1998. Conservation status of Carex parryana ssp. idahoa in Montana. Montana Natural Heritage Program, Helena, MT.

Lesica, P. and F. W. Allendorf. 1995. When are peripheral populations important for conservation? Conservation Biology 9: 753-760 
Lesica, P.., G. Moore, K. M. Peterson and J. H. Rumely. 1984. Vascular plants of limited distribution in Montana. Monograph No. 2, Montana Academy of Sciences, Supplement to the Proceedings Vol. 43.

Lesica, P. and L. A. Schassberger. 1988. Centennial Sandhills Preserve Design. Unpublished report to The Nature Conservancy, Helena, MT.

Lesica, P. and J. S. Shelly. 1992. Effects of cryptogamic soil crust on the population dynamics of Arabis fecunda (Brassicaceae). American Midl. Nat. 128:53-60.

Lesica, P. and J. S. Shelly. 1994. Demography and life history of Arabis fecunda in Ravalli and Beaverhead counties, Montana. Unpublished report to the Beaverhead National Forest. Montana Natural Heritage Program, Helena, MT. 29 pp.

Lesica, P. and J. S. Shelly. 1995. Effects of Reproductive Mode on Demography and Life History in Arabis fecunda (Brassicaceae). American Journal of Botany 82: 752-762.

Lesica, P. and B. M. Steele. 1994. Prolonged dormancy in vascular plants and implications for monitoring studies. Natural Areas Journal 14: 209-212.

Lesica, P. and J. Vanderhorst. 1995. Sensitive plant survey of the Sage Creek area, Beaverhead County, Montana. Montana Natural Heritage Program, Helena, MT.

Lesica, P. and S. V. Cooper. 1996. Plant succession in the Centennial Sandhills of Beaverhead County, Montana: A description and model with utility for management. Montana Natural Heritage Program, Helena.
Lesica, P. and S. V. Cooper. 1999. Succession and disturbance in sandhills vegetation: constructing models for managing biological diversity. Conservation Biology 13: 293-302.

Lindborg, R. and J. Ehrlen. 2002. Evaluating the risk of a perennial herb: demographic data versus historical records. Conservation Biology 16: 683-690.

Love, R. M. 2003. Idaho floristics: L. E. Henderson and his mislabelled 1895 collections from the Lost River Mountains of eastern Idaho. Madrono 50: 200-202.

Mathias, M. E. and L. Constance. 1944-45. Umbelliferae. North American Flora 28B 43-297.

Montana Natural Heritage Program. 2003. Plant species of concern. Montana State Library, Helena.

Mansfield, D. H., and H. Miyasaki. 1993. Analysis of the habitat requirements of Primula alcalina. Challenge Cost Share Project, Albertson College of Idaho and Salmon District, Bureau of Land Management. 84 pp.

Moseley, R. K. 1989. Report on the conservation status of Primula alcalina, a proposed candidate species. Prepared for Idaho Department of Parks and Recreation. 32 pp. plus appendices.

Moseley, R. K. 1995. Demographic monitoring of Primula alcalina (alkali primrose): 19911994. Conservation Data Center, Idaho Dept. of Fish and Game. 27 pp. plus appendices.

Moseley, R. K., M. Mancuso and J. Hilty. 1990. Field investigation and status survey of Penstemon lemhiensis (Lemhi penstemon) in Idaho. Unpublished report, Natural Heritage Program, Idaho Dept. of Fish \& Game, Boise. 
Muir, P. S. and R. K. Moseley. 1994. Responses of Primula alcalina, a threatened species of alkaline seeps, to site and grazing. Natural Areas Journal 14: 269-279.

Munz, P. A. 1931. The subgenus Anogra of the genus Oenothera. American Journal of Botany 18: 309-327.

Murray, D. F. 2002. Carex sect. Ramosae. In: Flora of North America Editorial Committee, Flora of North America, Volume 23, Cyperaceae. Oxford University Press, New York.

NatureServe. 2003. NatureServe Explorer: An online encyclopedia of life [web application]. Version 1.8. NatureServe, Arlington, Virginia. Available http:// www.natureserve.org/explorer. (Accessed: January 6, 2004).

NOAA; National Oceanic and Atmospheric Association. 1982. Monthly normals of temperature, precipitation and heating and cooling degree days. Montana, 1951-1980. National Climate Center, Ashville, NC.

Nelson, J. R. 1985. Rare plant surveys: techniques for impact assessment. Natural Areas Journal 5(3): 18-30.

Panzer, R. and M. W. Schwartz. 1998. Effectiveness of a vegetation-based approach to insect conservation. Conservation Biology 12: 693-702.

Perry, E. S. 1962. Montana in the geologic past. Montana Bureau of Mines and Geology Bulletin 26, Butte.

Pohl, K. undated. A pilot investigation into the fire history of the montane forest of the Centennial Mountains, southwestern Montana: 1743-2000. Unpublished report prepared for The Nature Conservancy, Helena, MT.
Reid, W. V. 1998. Biodiversity hotspots. Trends in Ecology and Evolution 13: 275-279.

Reveal, J.L. and C.R. Bjork. 2004. Eriogonum soliceps (Polygonaceae: Eriogonoideae), a new species from east-central Idaho and southwestern Montana. Brittonia 56 (in press).

Schassberger, L. A. 1988. Effects of grazing on the habitat of Astragalus ceramicus var. apus in the sandhills of the Centennial Valley, Montana. M.S. thesis, University of Montana, Missoula.

Shelly, J. S. 1987. Status review of Penstemon lemhiensis; U.S. Forest Service- Region 1, Beaverhead and Bitterroot National Forests. Montana Natural Heritage Program, Helena, MT.

Shelly, J. S. 1990. Report on the conservation status of Penstemon lemhiensis, a candidate threatened species: Montana. Unpublished report to the U.S. Fish and Wildlife Service, Denver. Montana Natural Heritage Program, Helena, MT. 89 pp.

Vanderhorst, J. 1995a. Sensitive plant survey of the Tendoy Mountains in the Beaverhead National Forest, Beaverhead County, MT. Montana Natural Heritage Program, Helena, MT.

Vanderhorst, J. 1995b. Sensitive plant survey in the Horse Prairie Creek drainage, Beaverhead County, Montana. Montana Natural Heritage Program, Helena, MT.

Vanderhorst, J. 1995c. Survey of Bannack State Park and vicinity for Montana plant species of special concern. Montana Natural Heritage Program, Helena, MT. 
Vanderhorst, J. 1995d. Report on the conservation status of Lesquerella carinata var. languida, a candidate threatened species. Unpublished report to the Bureau of Land Management and the U.S. Fish and Wildlife Service. Montana Natural Heritage Program, Helena, Montana. 56 pp.

Vanderhorst, J. and B. L. Heidel. 1998. Conservation status of Lomatium attenuatum Evert in Montana. Unpublished report to the Bureau of Land Management. Montana Natural Heritage Program, Helena.

Vanderhorst, J. and P. Lesica. 1994. Sensitive plant survey in the Tendoy Mountains, Beaverhead County, Montana. Montana Natural Heritage Program, Helena, MT. 


\section{Appendix A. Global/State Rank Definitions}




\section{Heritage Program Ranks}

The international network of Natural Heritage Programs employs a standardized ranking system to denote global (range-wide) and state status. Species are assigned numeric ranks ranging from 1 to 5, reflecting the relative degree to which they are "at-risk". Rank definitions are given below. A number of factors are considered in assigning ranks - the number, size and distribution of known "occurrences" or populations, population trends (if known), habitat sensitivity, and threat. Factors in a species' life history that make it especially vulnerable are also considered (e.g., dependence on a specific pollinator).

Global Rank Definitions (NatureServe 2003)

G1 Critically imperiled because of extreme rarity and/or other factors making it highly vulnerable to extinction

G2 Imperiled because of rarity and/or other factors making it vulnerable to extinction

G3 Vulnerable because of rarity or restricted range and/or other factors, even though it may be abundant at some of its locations

G4 Apparently secure, though it may be quite rare in parts of its range, especially at the periphery

G5 Demonstrably secure, though it may be quite rare in parts of its range, especially at the periphery

T1-5 Infraspecific Taxon (trinomial) — The status of infraspecific taxa (subspecies or varieties) are indicated by a “T-rank” following the species' global rank

\section{State RANK Definitions}

S1

S2

S3

S4

S5

At high risk because of extremely limited and potentially declining numbers, extent and/or habitat, making it highly vulnerable to extirpation in the state At risk because of very limited and potentially declining numbers, extent and/or habitat, making it vulnerable to extirpation in the state

Potentially at risk because of limited and potentially declining numbers, extent and/or habitat, even though it may be abundant in some areas

Uncommon but not rare (although it may be rare in parts of its range), and usually widespread. Apparently not vulnerable in most of its range, but possibly cause for long-term concern Common, widespread, and abundant (although it may be rare in parts of its range). Not vulnerable in most of its range

\section{Combination RANKS}

G\#G\# or S\#S\# Range Rank-A numeric range rank (e.g., G2G3) used to indicate uncertainty about the exact status of a taxon

\section{QUALIFIERS}

NR Not ranked 
Presumed Extinct-Species believed to be extinct throughout its range. Not located despite intensive searches of historical sites and other appropriate habitat, and virtually no likelihood that it will be rediscovered

$\mathrm{H}$

$\mathrm{U}$

HYB

?

$\mathrm{C}$

A

Z

$\mathrm{P}$

$\mathrm{R}$

SYN

$*$

B

$\mathrm{N}$

Possibly Extinct-Species known from only historical occurrences, but may never-theless still be extant; further searching needed

Unrankable-Species currently unrankable due to lack of information or due to substantially conflicting information about status or trends

Hybrid—Entity not ranked because it represents an interspecific hybrid and not a species

Inexact Numeric Rank-Denotes inexact numeric rank

Captive or Cultivated Only-Species at present is extant only in captivity or cultivation, or as a reintroduced population not yet established

Accidental-Species is accidental or casual in Montana, in other words, infrequent and outside usual range. Includes species (usually birds or butterflies) recorded once or only a few times at a location. A few of these species may have bred on the one or two occasions they were recorded

Zero Occurrences-Species is present but lacking practical conservation concern in Montana because there are no definable occurrences, although the taxon is native and appears regularly in Montana

Potential-Potential that species occurs in Montana but no extant or historic occurrences are accepted

Reported-Species reported in Montana but without a basis for either accepting or rejecting the report, or the report not yet reviewed locally. Some of these are very recent discoveries for which the program has not yet received first-hand information; others are old, obscure reports

Synonym - Species reported as occurring in Montana, but the Montana Natural Heritage Program does not recognize the taxon; therefore the species is not assigned a rank

A rank has been assigned and is under review. Contact the Montana Natural Heritage Program for assigned rank

Breeding-Rank refers to the breeding population of the species in Montana

Nonbreeding - Rank refers to the non-breeding population of the species in Montana 
Appendix B. Globally rare SPecies accounts 


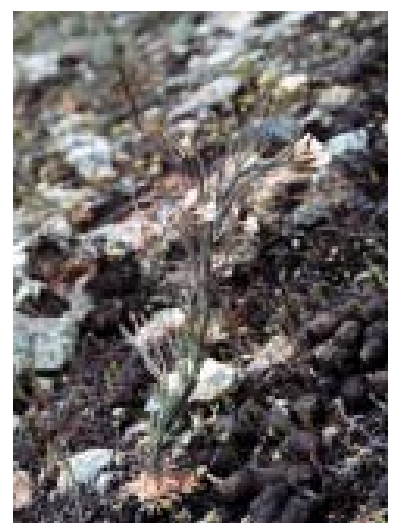

Arabis fecunda, Charlie's Gulch, Ravalli Co.

\title{
Arabis fecunda
}

\section{Sapphire rockcress}

\author{
BLM Status: Sensitive \\ Heritage Ranking: G2; S2
}

RANK JUSTIFICATION: Sapphire rockcress is a state endemic known from several locations in three mountain ranges where it is restricted to specific and localized habitats. Encroachment of spotted knapweed threatens several populations that may be genetically distinct. It is unclear whether grazing has significant negative impacts.

IDENTIFICATION: Arabis fecunda is a small perennial with 1 to many clusters of basal leaves arising from a simple or branched rootcrown and 1 to many, unbranched, flowering stems that are up to $30 \mathrm{~cm}$ high. The spoon-shaped or lance-shaped basal leaves are 10-30 mm long and 2-4 mm wide, with entire margins or a few shallow lobes toward the tip; the stem leaves are smaller and clasping. Usually two distinct types of basal leaves can be distinguished: larger, broader ones produced in the fall, and narrower ones produced in the spring. The leaves and stem are grayish-white with a dense cover of small, branched hairs. The several to many white or blush-tinged flowers are borne in an unbranched spike-like inflorescence. Flowers are tightly clustered at first, but become further apart in fruit; they have 4 petals, which are 9-13 mm long and 3-5 mm wide, and densely hairy sepals, which are 6-7 mm long and ca. $2 \mathrm{~mm}$ wide. The grayish, hairy fruits are 3-5 cm long and 1-2 mm wide; they are held nearly erect when mature and have two narrow chambers with a single row of small seeds in each one. Flowering from late April-early June.

The relatively small size and densely hairy erect fruits of Arabis fecunda are distinctive. Arabis hirsuta and A. glabra have erect fruits, but are taller and have larger leaves. Arabis drummondii, A. divaricarpa and $A$. lyallii also have erect fruits, but these are glabrous rather than densely hairy.

HABITAT: Sapphire rockcress is endemic to the Northern Rocky Mountains of southwest Montana. It reaches its northern extent in the western foothills of the Sapphire Range in the Willow Creek drainage (Ravalli County) and extends south to the northern foothills and mountains of the East Pioneer Range (Beaverhead County, lower Big Hole River drainage) and the Highland Mountains (Silver Bow County).

The species occurs on moderate to steep slopes with warm (SE, S, SW, W) aspects and relatively sparse vegetation. Most sites are in lower slope positions, although populations do occur on mid

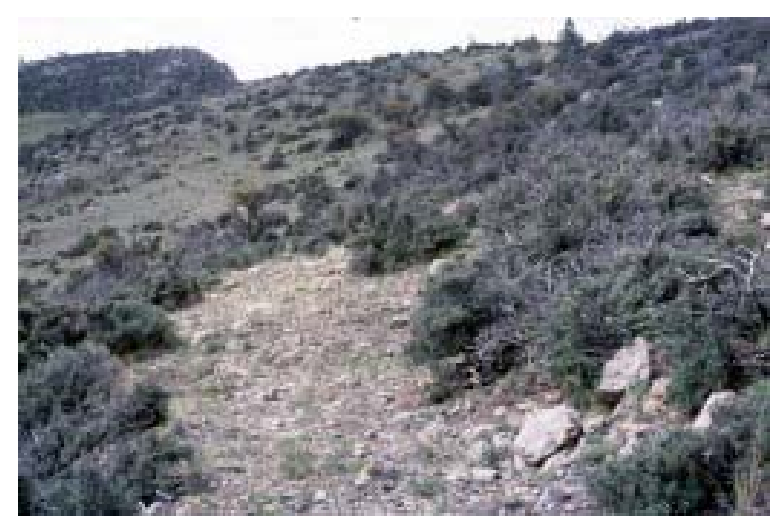

Arabis fecunda habitat, Soap Gulch, Beaverhead Co. and upper slopes. Sites in the Sapphire Mountains are at or below $5000 \mathrm{ft}$. while populations in the southern portion of the range are 5500-8000 ft. Sapphire rockcress occurs on soils derived exclusively from calcareous sediments that have been metamorphosed to some extent by contact with granitic intrusions (Lesica 1993). Soils are generally sandy in texture with low organic matter content and a light albedo. Soil analyses from the Charley's Gulch site in Ravalli County indicate a silty-sand texture and high calcium content. Parent materials from Ravalli County belong to the Wallace Formation in the Precambrian Belt Series, while those from Beaverhead and Silver Bow Counties are Paleozoic Madison limestone. 
In Ravalli County, zonal vegetation is typically Artemisia tridentata/Festuca idahoensis/ Agropyron spicatum steppe, sometimes with a sparse overstory of Pinus ponderosa. In Beaverhead and Silver Bow Counties, it grows in Cercocarpus ledifolius, Juniperus scopulorum or Pinus flexilis woodland, very open Pseudotsuga menziesii forest, or sparse Agropyron spicatum grassland.

ECOLOGY: Sapphire rockcress occurs in areas of relatively sparse vegetation. At three sites in Ravalli and Beaverhead Counties, coverage of bare soil varied from $40-80 \%$, and basal vegetation from $20-50 \%$ (Lesica and Shelly 1994). Many of the sites occur on steep slopes with periodic natural erosion. In some cases these slopes support cryptogamic soil crusts that are beneficial to the survival of older, larger individuals of the species (Lesica and Shelly 1992).

Periodic erosion and slumping of steep slope habitat may be partially responsible for maintaining sparse vegetation with reduced competition for light, water and nutrients (Lesica 1993). Many sites would be considered early successional or edaphic disclimaxes, and these conditions may be important for

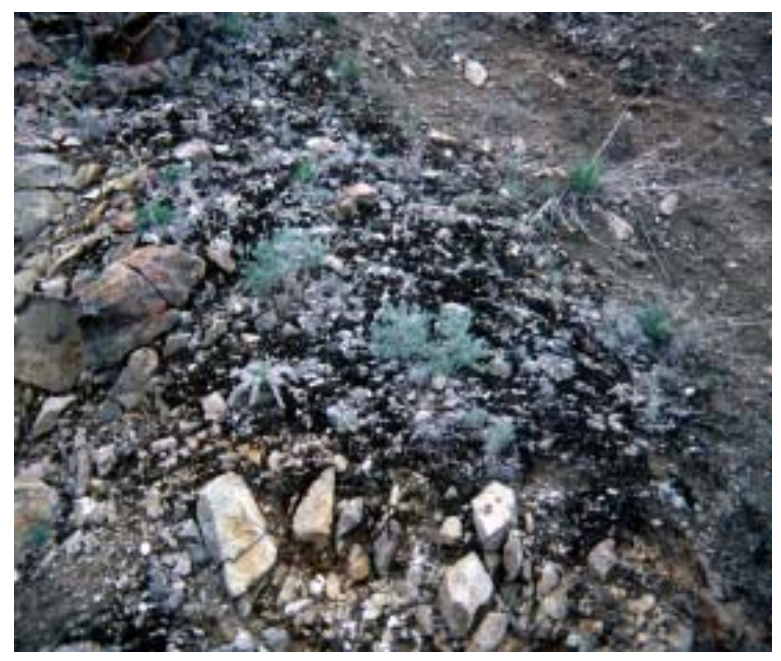

Arabis fecunda growing in soil crust, Birch Creek the species persistence. Fire was relatively frequent in many of these areas, but the sparse vegetation on the slopes occupied by this species probably did not carry fire well.

MANAGEMENT CONSIDERATIONS: Several factors may affect the long-term persistence of this species, including exotic weed encroachment, grazing, herbicide application, mining and pathogens. Spotted knapweed (Centaurea maculosa) has severely invaded Arabis fecunda habitat in Ravalli County, and studies have shown reduced recruitment of new plants into the population. Spotted knapweed is an aggressive Eurasian weed present at all sites in Ravalli County. This taprooted perennial is widely introduced in North America where it has become a serious invader of semi-arid grasslands in the Pacific Northwest and intermountain valleys of the Northern Rocky Mountains. Its ability to invade and replace native plants is well documented. Most of our Arabis fecunda sites have severe infestations of spotted knapweed. It has been shown to have adverse effects on many native species including sapphire rockcress. Research on water-use efficiency in this species has shown significant differences between low-elevation populations in the Bitterroot Valley and those at higher sites in Beaverhead County, suggesting that Bitterroot Valley populations, which are most threatened by weed encroachment, may be genetically distinct.

Roads are a major source of weed infestation, and road construction or other major disturbances that may introduce or provide avenues for the introduction of weeds could negatively impact populations of sapphire rockcress. Livestock can also be a significant vector for exotic weed encroachment. Currently, spotted knapweed does not occur at the Beaverhead or Silver Bow County sites, but it does occur in these counties and may become a problem.

Livestock grazing occurs at most sites, although heavy grazing is reported for fewer than half of the sites. Direct herbivory has never been observed and is probably rare, however, soil crusts are beneficial to the species' survivorship at some sites; such crusts are often destroyed by livestock. Livestock can also adversely affect survivorship by trampling plants. Exclosure studies were conducted at two sites near the Big Hole River. At one site sapphire rockcress increased in the grazing exclosure while decreased in another. Sapphire rockcress establishes best when not competing with other species, and grazing may limit competition. It is interesting to note that some of the largest populations (Birch Creek and Jerry Creek) are in areas with the most intensive grazing. 
Herbicide application is currently the most commonly employed method for controlling spotted knapweed infestations, however, little is known about the specific effects on sapphire rockcress, so herbicide application should be avoided in direct proximity to sapphire rockcress populations. At this time only one sapphire rockcress site is near an active mine, and it has not been impacted to date. Nonetheless, there are populations near mining claims or inactive mines that could become active with improved extraction methods or increases in the value of minerals. 


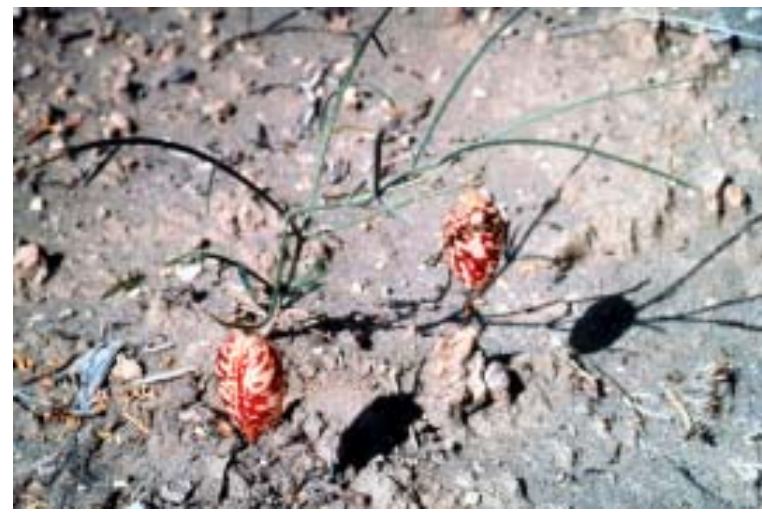

Astragalus ceramicus var. apus, Idaho

Astragalus ceramicus var. apus

Painted milkvetch

BLM Status: Sensitive

Heritage Ranking: G4T3; S1

RANK JUSTIFICATION: Astragalus ceramicus var. apus is known only from the upper Snake River Plains of southeast Idaho and adjacent Montana where it is found only in the Centennial Valley of Beaverhead County. The removal of natural disturbance regimes, including fire, ungulate grazing and pocket gopher activity, can result in dune stabilization, reducing the extent of early seral blowout vegetation upon which this species depends. Portions of its habitat lie on private or public lands without sensitive species management policies in place.

IDENTIFICATION: Painted Milkvetch is a slender, wiry, herbaceous perennial with trailing or ascending stems, 3-20 cm long, arising from long, widely spreading, rhizome-like rootcrown branches. Alternate, pinnately compound leaves are 2-17 cm long and have 1-4 pairs of narrow, stem-like, lateral leaflets. Foliage is sparsely covered with unbranched, short, white hairs. Flower stalks are $2-8 \mathrm{~cm}$ long, each with 2-15 widely spaced flowers. The white, pea-like flowers have an erect upper petal, 6-11 mm long, and a calyx, 3-6 mm long, sparsely covered with long white or black hairs. Egg-shaped, inflated fruits, 15-50 mm long, are mottled with purple. They often lie on the ground like miniature balloons that pop when squeezed or stepped on. Flowering in late June-July.

The purple-mottled, inflated fruits combined with linear leaflets are diagnostic traits for Astragalus ceramicus. The variety filifolius, found in eastern Montana has pods with a short stalk coming out of the calyx. The pods are sessile in var. apus.

HABITAT: The species is associated with early successional habitats in sandhills (Schassberger 1988). It is found in sandy, welldrained blowout areas and sandy flats or draws of old sand dunes at elevations of 6650-6700 ft., on moderately steep (20-30\%), south- and west-facing slopes. The following grasses and forbs comprise much of the local vegetative cover: Artemisia astatete, Phacelia astate, Agropyron dasystachyum, Stipa comata and Tetradymia canescens.

ECOLOGY: Astragalus ceramicus var. apus occurs in the sand dune region of the Centennial Valley where there is light to

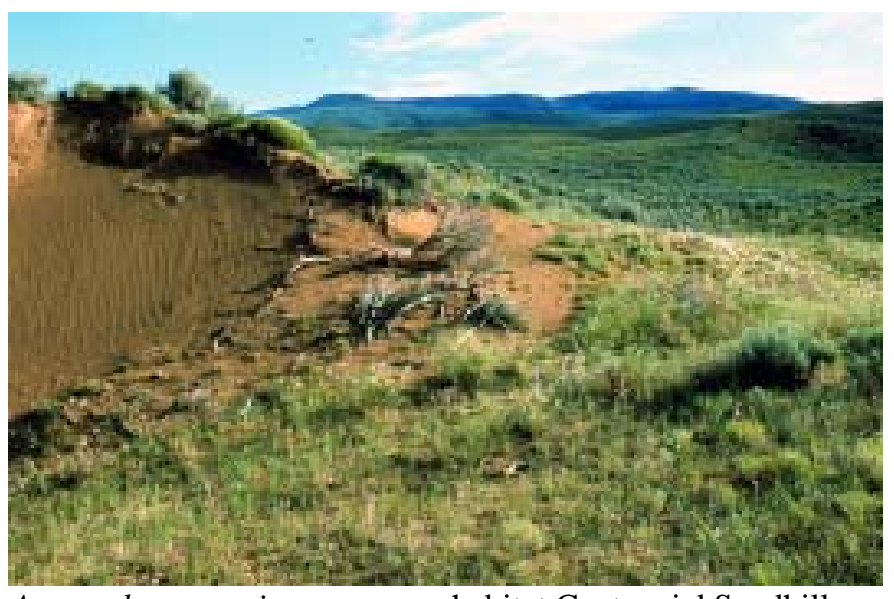

Astragalus ceramicus var. apus habitat,Centennial Sandhills, Beaverhead Co.

moderate grazing pressure (Culver 1993). Painted milkvetch requires the open sand of early seral vegetation, and suitable habitat may be reduced when plant succession leads to later seral stages in which vegetation colonizes areas of formerly open sand (Lesica and Cooper 1998). Historically, the diversity of sandhills plant communities was maintained by a fire cycle of 20-30 years and pocket gopher activity (Lesica and Cooper 1998). Pocket gopher (Thomomys talpoides) activity also appears to be an important force in initiating blowouts and maintaining early seral vegetation. 
In 1987, the populations in the Centennial Sandhills were reported to be thriving, however in 1993, Culver observed only a few small populations. These observations suggest that the number of aboveground stems may vary from year to year.

MANAGEMENT CONSIDERATIONS: The removal of natural disturbance regimes, including fire, ungulate grazing and pocket gopher activity, leads to dune stabilization, reducing the extent of early seral blowout vegetation upon which this species depends. Painted milkvetch would benefit from restoration of the fire regime and moderate grazing, at least in years following burns. Severe destabilization of the dunes, e.g., from off-road vehicle use, can also threaten its habitat. 


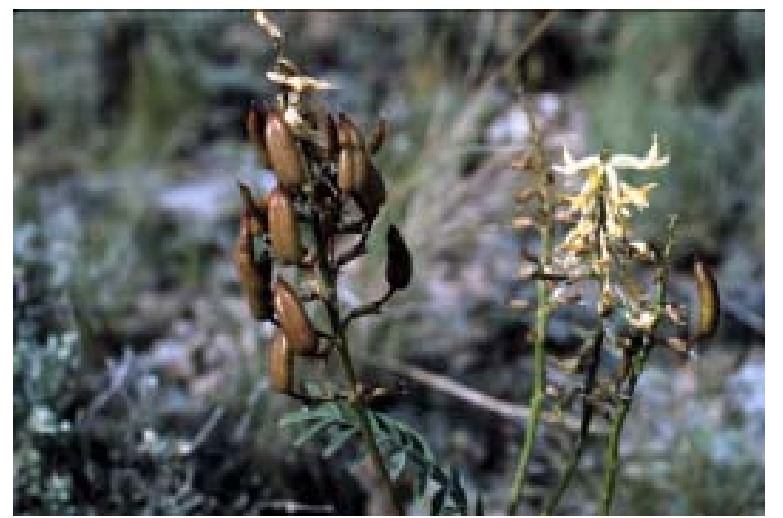

Astragalus scaphoides, Spring Gulch
Astragalus scaphoides

Bitterroot milkvetch

BLM Status: Sensitive

Heritage Ranking: G3; S2

RANK JUSTIFICATION: Astragalus scaphoides occurs only in Lemhi County, Idaho and Beaverhead County, Montana. In Montana, the several documented occurrences are confined to a small area from the Grasshopper Creek drainage south to the Tendoy Mountains. The total number of individual plants has been estimated at tens of thousands, but occupied habitat may be less than 700 acres. The species is palatable, and is sensitive to intensive grazing, especially during spring and early summer.

IDENTIFICATION: Bitterroot Milkvetch is a stout, herbaceous perennial with several erect stems arising 2-6 dm high from a branched rootcrown. The pinnately compound leaves are $10-25 \mathrm{~cm}$ long with 15-21 narrowly elliptic leaflets. Foliage is glabrous to sparsely hairy. Inflorescences are borne in the axils of upper leaves and have 15-30 spreading, crowded flowers that become more remote as the plant matures. The yellowish flowers are ca. $20 \mathrm{~mm}$ long with a reflexed upper petal and a blackish-hairy calyx that is 8-10 mm long. The glabrous, green to reddish oblong pods are 15-20 mm long, 4-6 mm wide and 2chambered in cross-section. Each pod is borne on a stalk of approximately equal length that spreads out and then arches up, holding the fruit nearly erect. Flowering in late May-early June, mature fruit in July.

Astragalus atropubescens is similar, but has white flowers and smaller-diameter (2-4 mm) fruits borne on sharply erect (immediately ascending) stalks. Astragalus canadensis also has sharply erect fruit stalks. Astragalus terminalis has white flowers and unstalked fruits.

HABITAT: Astragalus scaphoides occurs in sagebrush grassland, generally with a dense cover of sagebrush on silty soils with a moderate to high content of coarse material derived from limestone, basalt or diabase (Lesica 1984). Populations are often found in the ecotonal area between rocky, steep upper slopes and nearly level benches along drainageways, and it seems to be most frequent on warmer, south- and southwest-facing slopes. The habitat usually has a high percentage of bare ground and other shrub species sometimes dominate. Frequently associated species include Artemisia tridentata, Chrysothamnus nauseosus, Artemisia nova, Agropyron

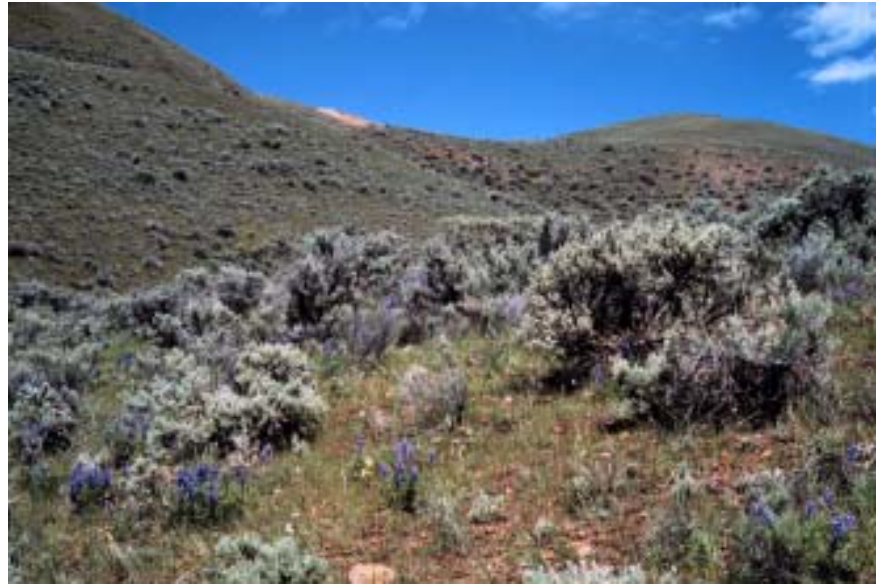

Astragalus scaphoides habitat, Agency Creek, Lemhi Co., Idaho

spicatum, Agropyron smithii, Stipa comata, Oryzopsis hymenoides, Opuntia polyacantha, Gutierrezia sarothrae, Phlox hoodii and Artemisia frigida.

ECOLOGY: The number of above-ground stems is highly variable among years, making accurate inventories difficult to conduct (Lesica 1995). 


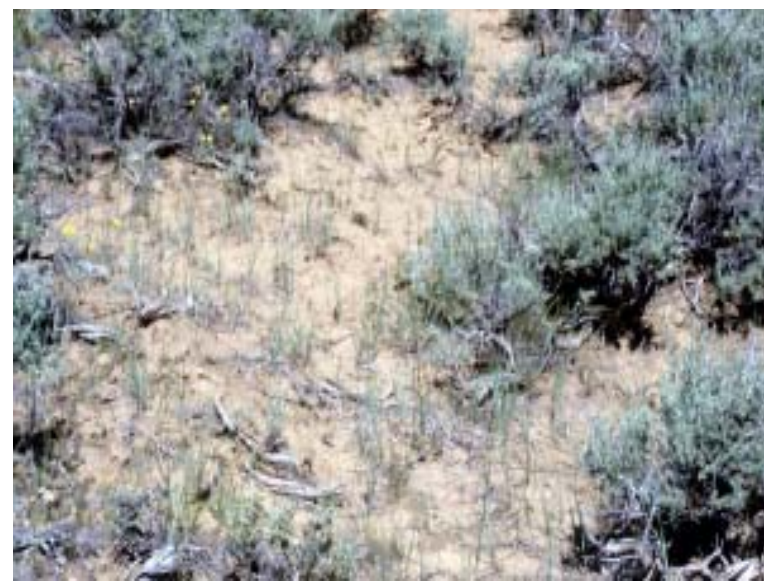

Astragalus scaphoides habitat, Sheep Corral Gulch

MANAGEMENT CONSIDERATIONS: The tendency of this species to occur on lower slopes above drainages makes it particularly vulnerable to road construction (Lesica 1984), which has likely impacted some populations.

Herbivory by insects and mammals may limit the reproductive ability of this species (Lesica 1984, 1995). However, three sample populations remained stable or increased in size in spite of significant seed predation (Lesica 1995). Plants are most vulnerable to grazing as they mature, between May 15 and July 15 . Limiting of livestock grazing during this period minimizes soil compaction and damage to reproductive plants (Lesica 1984). Rest-rotation grazing regimes may allow recruitment adequate to maintain stable populations, while chronic severe grazing could reduce adult vigor and lead to population decline (Lesica 1995). 


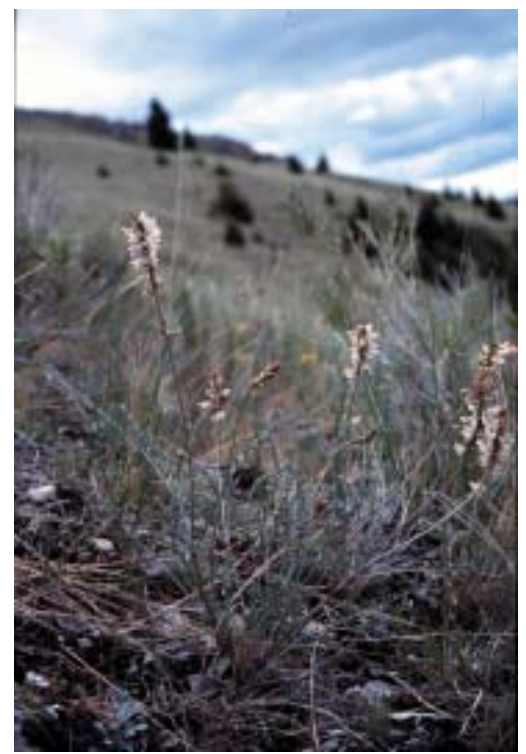

Astragalus terminalis, Tendoy Mtns., Beaverhead Co.

\section{Astragalus terminalis}

\section{Railhead milkvetch}

\author{
BLM Status: Sensitive
}

Heritage ranking: G3; S2

RANK JUSTIFICATION: Astragalus terminalis is known from southwest Montana, east-central Idaho and northwest Wyoming. In Montana it is known from 10-20 occurrences in the Beaverhead County and the Upper Madison River Valley. The species is vulnerable to intensive grazing and competition from noxious weeds, at least in low-elevation areas.

IDENTIFICATION: Railhead Milkvetch is a tufted perennial herb with several erect stems that arise $5-30 \mathrm{~cm}$ high from a taproot. The pinnately compound leaves are 5-20 cm long with 13-21 oblong leaflets that have blunt tips. Foliage is sparsely covered with gray hairs that branch at the base and spread in opposite directions appressed to the surface of leaves or stem. Inflorescences are borne in the axils of upper leaves and have 10-30 spreading, crowded flowers that become more remote as the plant matures. The white, pea-like flowers are 12-16 $\mathrm{mm}$ long, each with a reflexed upper petal and a purple-spotted lower petal. The calyx is covered with white or black hairs and is 4-5 mm long. The glabrous, cigar-shaped fruits lack a basal stem, are 3-sided in cross-section, and are 15-20 mm long. The alpine ecotype is much smaller than plants from the valleys. Flowering occurs from June to mid-July.

Astragalus atropubescens, A. canadensis and $A$. scaphoides all have stalked fruits, and the latter two species usually have yellowish flowers.

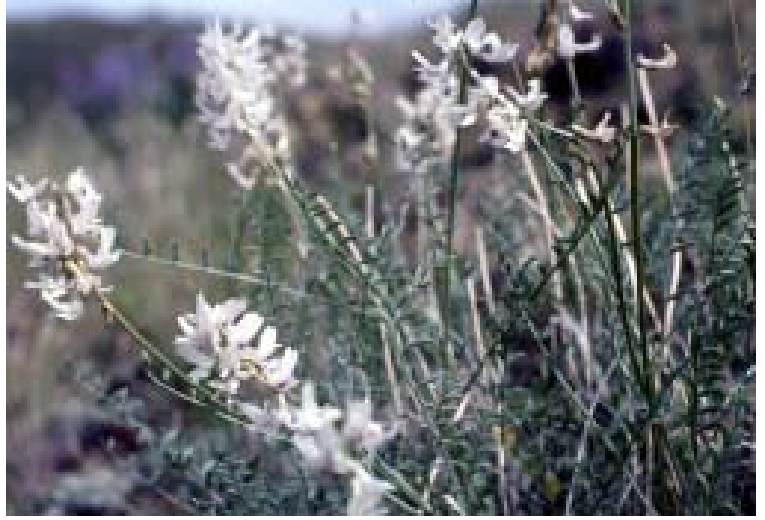

Astragalus terminalis, Grasshopper Creek Drainage, Beaverhead Co.

HABITAT: For the Intermountain Region, Barneby (1989) describes this species' habitat as “open, stony hillsides and benches along rivers, commonly associated with low sagebrush and calcareous bedrock.” In Montana, its habitat ranges from valley grasslands (Idaho fescue/bluebunch wheatgrass) and open eroding slopes, to ridgetops, barren clay buttes and dry subalpine meadow. Thus, it is difficult to predict where this species will occur.

Southeast of Bannack, it is found on sagebrush and grassland slopes between more gentle slopes. At another site in Beaverhead County, it grows in grasslands dominated by bluebunch wheatgrass and needle-and-thread grass, sometimes with sagebrush (Artemisia tridentata and A. tripartita). In the Centennial Valley, it occurs in an Artemisia tridentata-Festuca idahoensis community. In the Upper Madison Valley, it grows in fine-textured soils at the base of eroding, sparsely vegetated slopes. This species appears to favor relatively barren sites that are often alkaline (Heidel and Vanderhorst 1996), and frequently occurs with other "barren site indicators," such as Astragalus vexilliflexus and Haplopappus acaulis (Lesica and Vanderhorst 1995).

ECOLOGY: Astragalus terminalis may demonstrate prolonged dormancy because it is morphologically similar and closely related to $A$. scaphoides, which has been shown to remain dormant in some years 
(Lesica 1995). Therefore, the number of above-ground stems may be highly variable among years, making accurate inventories difficult to conduct (Lesica and Steele 1994).

\section{MANAGEMENT CONSIDERATIONS:}

Observations suggest that Railhead Milkvetch is palatable and may decrease under some livestock grazing regimes. In one exclosure in the Upper Madison Valley, plants were much denser inside than outside; and many of the plants in a nearby population had inflorescences removed, probably by game. No plants were found across the cattle guard in a grazed pasture (Heidel and Vanderhorst 1996).

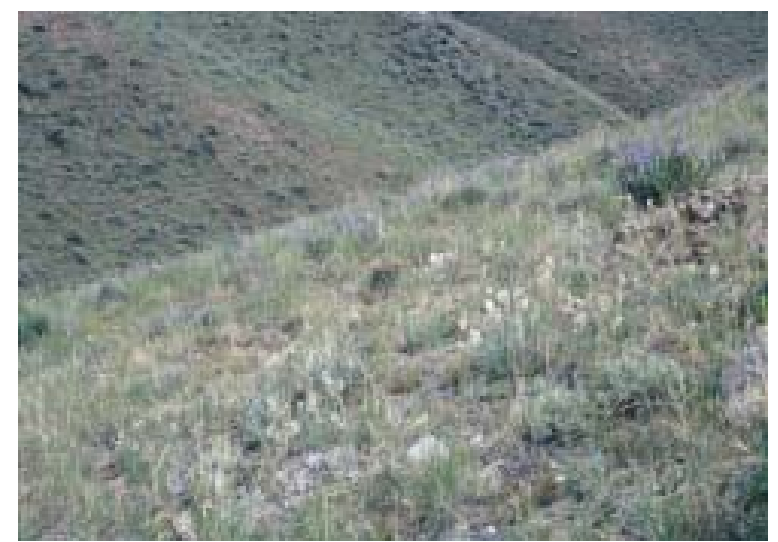

Astragalus terminalis habitat, Grasshopper Creek Drainage, Beaverhead Co.

Astragalus terminalis faces competition from invasive weeds, especially spotted knapweed, yellow sweet-clover and cheatgrass. Centaurea maculosa (spotted knapweed) is invading this species' habitat from roadsides in the Upper Madison Valley (Heidel and Vanderhorst 1996), and has the potential to establish and compete aggressively there and at other sites in the state. Melilotus officinalis (yellow sweet-clover) and Bromus tectorum (cheatgrass) were documented invading a site in Beaverhead County. 


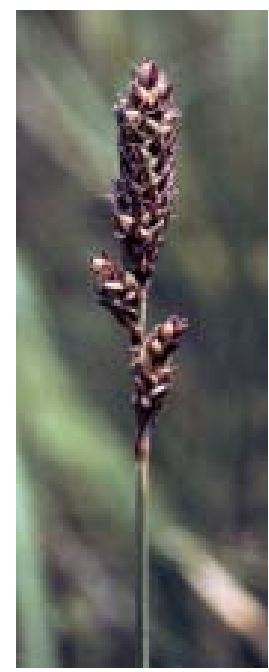

Carex idahoa, Beaverhead Co.

\section{Carex idahoa (Carex parryana ssp. idahoa) \\ Idaho sedge}

BLM Status: Sensitive

Heritage ranking: G2; S2

RANK JUSTIFICATION: Carex idahoa is a regional endemic known from just over 30 sites in Montana, most on public lands. The estimated number of stems reaches tens of thousands, but total occupied habitat is estimated at less than 200 acres. The species is palatable and populations may be affected by heavy grazing. Other risks are competition from exotic species, hydrologic alterations, agricultural development and road construction/maintenance.

IDENTIFICATION: Idaho sedge forms small clumps that arise from rhizomes. The stems are 20-35 cm high with most leaves crowded near the base. Leaves are flat and 2-4 mm wide. Flowers are clustered in 1-4 oblong-cylindrical spikes, each 1-3 cm long, with the uppermost being larger than the others. Male flowers are absent or scattered among the perigynia on the largest spike. The spikes form a narrow, interrupted head, subtended by small leaf-like bracts, at the top of the stems. The narrowly oval scales subtending each perigynia taper to the tip and are 2-3 times longer than the perigynia. These scales are brown with membranous margins and a distinct pale center. The glabrous, egg-shaped perigynia are yellow-green and about $3 \mathrm{~mm}$ long with a short beak. There are 3 stigmas and the seed is 3-sided. Fruits mature in July-August.

The uppermost spikes of $C$. p. ssp. parryana are cylindrical and more-or-less equal in size, while in C. idahoa and C. p. ssp. hallii, the terminal spike is enlarged and club-shaped. Female scales of C. p. ssp. hallii are as long as the perigynia, while they are much shorter than the perigynia in $C$. idahoa.

HABITAT: Carex idahoa occurs in moist alkaline meadows, often along streams (Vanderhorst and Lesica 1994). It most often occupies ecotonal areas between wet meadow and sagebrush steppe (Lesica 1998), and appears to be restricted to nearly level sites in the high valleys of southwest Montana. It is commonly found on terraces of headwaters streams above $6000 \mathrm{ft}$. elevation. Small populations may occur at lower elevations or along larger streams. Soils tend to be silty, with ample organic matter with little or no coarse material (Lesica 1998). Most documented Montana populations are in areas with calcareous

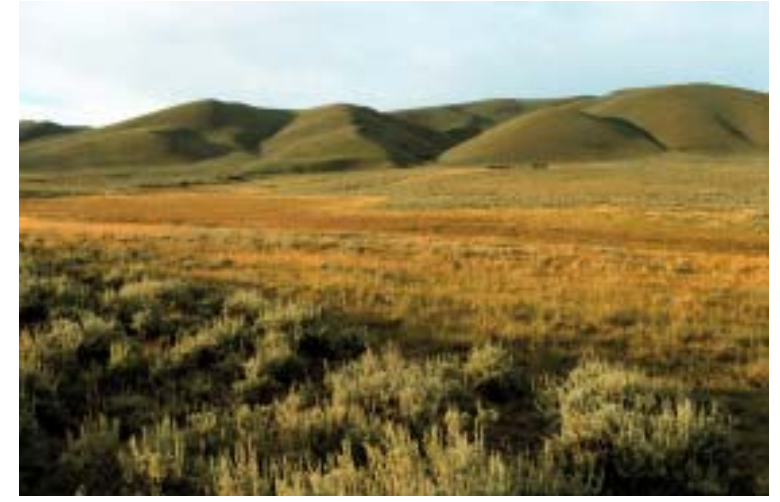
Carex idahoa habitat, Porcupine Creek parent material, however a few occupy non-calcareous sites.

Its moist, alkaline, streamside meadow habitat is typically dominated by graminoids (especially Deschampsia caespitosa, Juncus balticus, Carex praegracilis, Carex nebrascensis, C. aquatilis), with or without Potentilla fruticosa (Vanderhorst and Lesica 1994; Lesica 1998). Adjacent steppe vegetation is dominated by Artemisia tridentata and/or A. tripartita, Festuca idahoensis and Agropyron smithii. Species most commonly associated with Idaho sedge are (in order of importance) Juncus balticus, C. praegracilis, Muhlenbergia richardsonis, Aster occidentalis, Poa pratensis, Taraxacum officinale, Potentilla gracilis and Antennaria microphylla. Graminoid cover is high (60$100 \%$ ), and forb cover low to moderate (5-50\%) except in overgrazed areas. Bare ground averages $8 \%$ and cover of lichens and bryophytes averages 14\% (Lesica 1998). 
Idaho sedge consistently occurs in subirrigated soils associated with low-gradient streams or springs and seeps. These soils are wet early in the growing season but are only moist later in the summer. In wetlands where part of the habitat was saline (as indicated by the presence of Distichlis and Puccinellia), it is usually limited to non-saline areas, although it has been found in salt-encrusted soils (Lesica 1998).

ECOLOGY: Flooding is probably uncommon in most of these habitats, as they tend to occur in headwaters areas where snow accumulation and stream gradients are low (Lesica 1998). Although fire was common in high-elevation steppe vegetation in southwest Montana prior to European settlement, it probably did not play an important role in the dynamics of herbaceous riparian wetlands (Lesica 1998).

MANAGEMENT CONSIDERATIONS: Carex idahoa can probably tolerate light to moderate livestock grazing but will decline under heavy grazing (Lesica 1998). Its wetland habitat is favored by cattle and frequently subject to overgrazing on both public and private lands. Graminoids such as sedges are adapted to grazing and are usually able to persist with light to moderate grazing pressure (Lesica 1998). Evidence suggests that this species responds to grazing like a typical palatable graminoid, and is capable of tolerating light to moderate grazing, but would likely decline under continuous heavy grazing. This is based on correlation data and studies of other, anatomically similar species. Experiments and monitoring studies to determine the actual response of Idaho sedge have not been conducted (Lesica 1998); however grazing regimes that permit $50 \%$ or less annual utilization and allow seed production and dispersal at regular intervals will likely be compatible with its survival.

Almost all known populations of the species on public lands are subject to livestock grazing, as is much of its habitat on private land (Lesica 1998). Its mesic habitat provides high quality, green forage for livestock throughout the summer and is a magnet for cattle, often leading to overgrazing. Many of the small populations occur in localized springs, seeps or along small streams in extensive semi-arid steppe, and are particularly at risk from overgrazing, which can cause streambank destabilization followed by lowering of the water table and a loss of riparian vegetation (Lesica 1998). Populations in larger wetland areas may not face such intensive grazing pressure.

Large areas of potential habitat for this species in southern Beaverhead County are mowed for hay. While the effects of mowing on native vegetation are unknown, plowing and seeding of non-native species almost certainly have adverse effects on native communities and may result in local extirpation of native species. Poa pratensis (Kentucky bluegrass) is the only exotic plant documented with significant frequency in this species' habitat (Lesica 1998). It is a rhizomatous grass similar in stature to the Idaho sedge, and may compete with it, especially where there is grazing and trampling by livestock. Taraxacum officinale (dandelion) and Trifolium repens (clover) occur at some sites, but these are short plants that increase only where heavy grazing removes the larger graminoids, and by themselves do not pose a threat to Idaho sedge.

Roads are often constructed along or adjacent to riparian areas, and have impacted wetland habitat for three Idaho sedge populations (Lesica 1998). A fourth is vulnerable to road improvement and construction. Road development can reduce or degrade habitat through increased runoff, pollution and physical disturbance. Use of these roads for ranching and recreation probably has little impact on the species, however maintenance or widening can lead to habitat loss. A portion of Moose Creek, where one population occurs, has been dredged, presumably for mineral extraction (Lesica 1998). Dredging most likely reduces the extent and character of riparian vegetation, and may reduce habitat for Idaho sedge. Fortunately, most populations do not occur in areas prone to mining activity. 


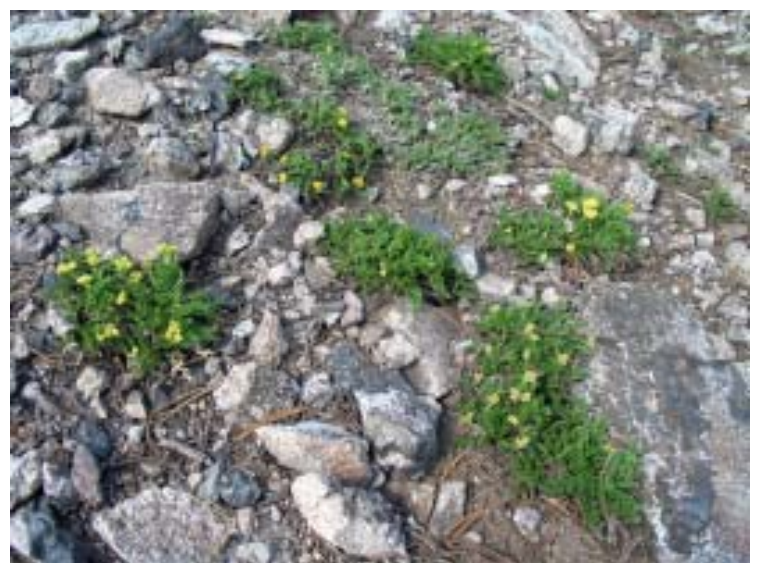

Cymopterus hendersonii, Ruby Range, Madison Co.
Cymopterus hendersonii (sensu stricto)

\section{Henderson's waferparsnip}

BLM Status: none

Heritage Ranking: GNR; (Preliminary State Rank) S2

RANK JUSTIFICATION: Cymopterus

hendersonii is currently known in Montana from four locations in the Bitterroot Range of Ravalli Co. and one location in the Madison Range, one location in the Gravelly Range and one location in the Ruby Range, all in Madison Co. All known populations are from high elevations.

IDENTIFICATION: Henderson's waferparsnip is a low, mat-forming perennial herb with a branched root crown covered in old leaf petioles. The petiolate leaves are all basal, 2-9 cm long and twice divided into well-separated, narrow segments. Herbage is glabrous or slightly roughened. The naked stems are 1-8 cm high, lax or erect. Small yellow flowers are born in a compound umbel subtended by 0-7 linear bracts. Each ultimate umbel is subtended by 3-7 narrow bracts, longer than the flowers. Fruits are elliptic, 2.5-5 $\mathrm{mm}$ long with 8 thickened, longitudinal wings protruding up to $1 \mathrm{~mm}$ above the surface. Flowering occurs in July and August.

Cymopterus nivalis (=C. bipinnatus) has white flowers and more membranous wings on the fruits. Cymopterus longilobus is a larger plant with most stems greater than $8 \mathrm{~cm}$ high. Cymopterus terebinthinus has short-hairy herbage.

HABITAT: Cymopterus hendersonii occurs in dry talus or skeletal soil of upper slopes and ridge crests at 2620-3000 m (8,600- $9600 \mathrm{ft}$.) in elevation. Associated vegetation is sparse and dominated by cushion plants. The plant is associated with limestone in Madison Co. and with granite or metamorphic parent material in Ravalli Co.

Cymopterus hendersonii was described from a collection made by Louis Henderson in east-central Idaho in 1895 (Coulter and Rose 1900). Subsequent treatments of the genus have placed similar plants from south-central Montana to Utah and Colorado into $C$. hendersonii (Mathias and Constance 1944-45, Cronquist 1961). However, Ronald Hartman has determined that the former plants are different from $C$.

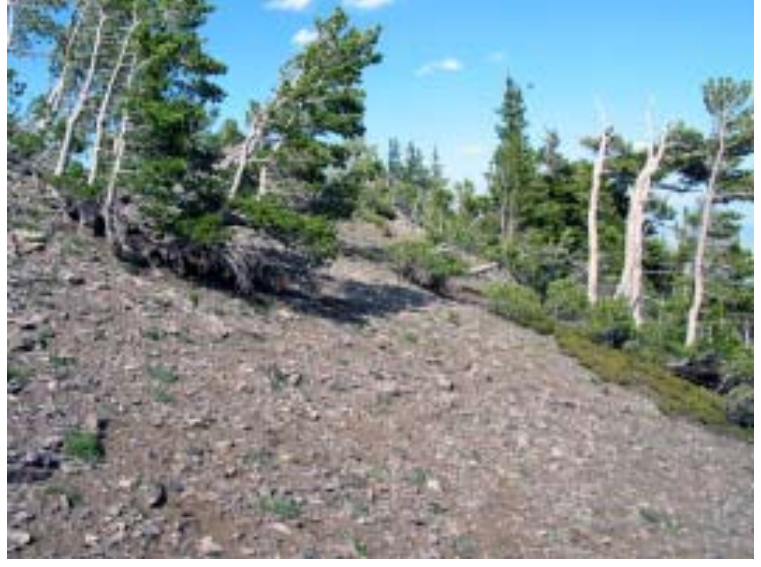

Cymopterus hendersonii habitat, Ruby Range, Madison Co. hendersonii and should rightly be called C. longilobus. True Cymopterus hendersonii is known from Madison and Ravalli counties in Montana (R. Hartman, personal communication) and east-central Idaho. Cronquist (1961) reported that the Henderson collection was made in Custer Co., but Love (2003) indicates it was from Lemhi Co.

ECOLOGY: Cymopterus hendersonii is a small plant and occupies habitats with sparse vegetation suggesting that it is not tolerant of competition. 
MANAGEMENT CONSIDERATIONS: Ravalli Co. populations all occur in the Selway-Bitterroot Wilderness. The Madison Range population also occurs in a wilderness area. The populations in the Ruby and Gravelly ranges are subject to livestock grazing; however, it is unlikely that these small forbs are palatable, and the sparsely vegetated habitat is probably not frequented by livestock. 


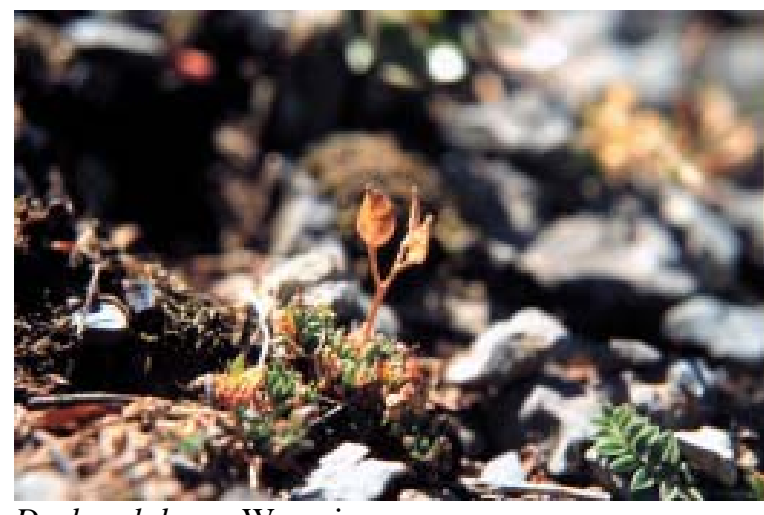

Draba globosa, Wyoming
Draba globosa

\section{Round-fruited Draba}

BLM Status: Watch

Heritage Ranking: G3; S1

RANK JUSTIFICATION: Round-fruited draba is a regional endemic, known from widely separated sites in Colorado, northeastern Utah, northwest Wyoming and adjacent Montana. It has been found in three southwest Montana mountain ranges, and the very few documented populations are quite small. However it's high-elevation habitat is relatively inaccessible, and there are no obvious threats.

IDENTIFICATION: Draba globosa is a low, perennial forming small mats of basal rosettes from a branched rootcrown. The tightly overlapping rosette leaves, 3-8 $\mathrm{mm}$ long, are lanceolate with pointed tips and glabrous except for scattered, unbranched hairs on the margin. Leafless stems are 5-30 mm tall. Few, stalked flowers are borne at the tip of the stem. The four pale yellow flowers are ca. $4 \mathrm{~mm}$ long. The flattened, ovate fruits are glabrous; 3-6 mm long and borne on spreading stalks 2-4 mm long.

Draba is a genus of many similar-appearing species. In Montana, Draba globosa, $D$.

densifolia and $D$. daviesiae are the only species with yellow flowers and leaves with glabrous upper surfaces but ciliate margins. Draba densifolia has pubescent fruits, while those of D. globosa and $D$. daviesiae are glabrous. The former has pointed leaves with 2-5 flowers, while the latter has rounded leaves and 5-10 flowers.

HABITAT: In Montana it has been found in the Madison and Centennial ranges, where it grows in moist, sparsely vegetated, often calcareous soil of moraine and fellfields, near or above treeline from 9,500 to $10,500 \mathrm{ft}$. in elevation. Associates include Silene acaulis, Ranunculus enscholtzii, Phlox pulvinata and Sibaldia procumbens.

MANAGEMENT CONSIDERATIONS: Roundfruited draba is found in inaccessible high-elevation sites, often in wilderness areas. There are no obvious threats to this species.

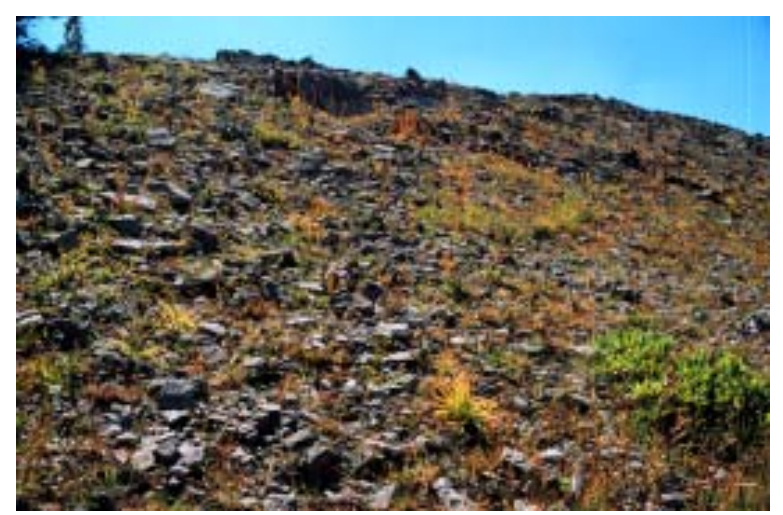

Draba globosa habitat, Wyoming 


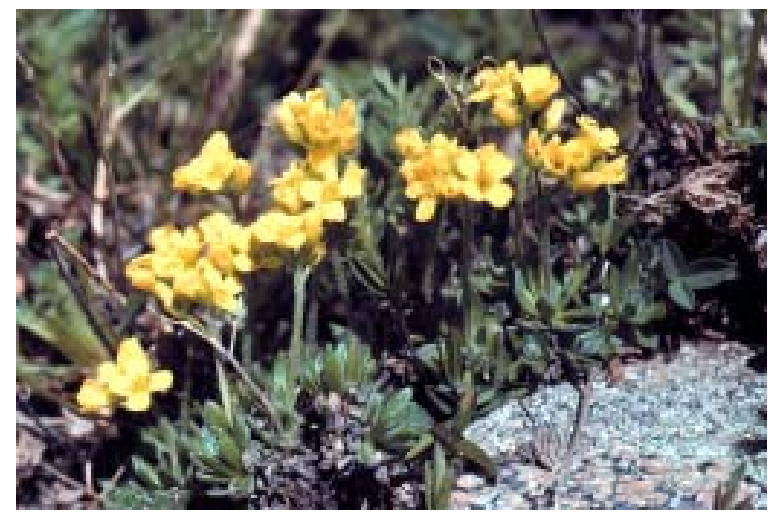

Draba ventosa, Beartooth Mtns., Carbon Co.

\section{Draba ventosa}

Wind River draba

BLM Status: none

Heritage Ranking: G3; S1

RANK JUSTIFICATION: Draba ventosa occurs from southwest Montana to Colorado and Utah. It is rare in all states in which it occurs except Wyoming. In Montana it has been found four times in four different mountain ranges- Madison, Pioneer, Snowcrest and Tobacco Root in Beaverhead and Madison counties. However the high elevation habitat is not threatened by anthropogenic disturbances except possibly mining. The Madison Range site is in a designated wilderness area.

IDENTIFICATION: Draba ventosa is a low, perennial forming loose mats from a branched root crown. The branches often trail downhill in its shifting talus habitat. The overlapping, elliptic rosette leaves are 5-12 mm long, ca. $4 \mathrm{~mm}$ wide and densely covered with tangled, branched hairs. Leafless stems are 2-4 cm long with 5-20 yellow flowers. The four petals are 4-5 mm long. The flattened, lanceshaped fruits are densely hairy and 5-8 mm long.

Draba is a genus of many similar-appearing species. In Montana, D. paysonii is the only other yellow-flowered, high-elevation, mat-forming species with tangled hair on the leaves, but it's largest leaves are up to $2 \mathrm{~mm}$ wide.

HABITAT: Draba ventosa occurs in scree and shifting talus of slopes near or above treeline, often but not always on limestone parent material. Associated species include Dryas octopetala, Saxifraga oppositifolia, Antennaria aromatica and Draba oligosperma.

ECOLOGY: Draba ventosa occupies habitats with sparse vegetation suggesting that it is not tolerant of competition.

MANAGEMENT CONSIDERATIONS: Wind River draba is found in inaccessible high-elevation sites. There are no immediate anthropogenic threats. However at least one site is in a historic mining district, so mining could pose a threat in the future. 


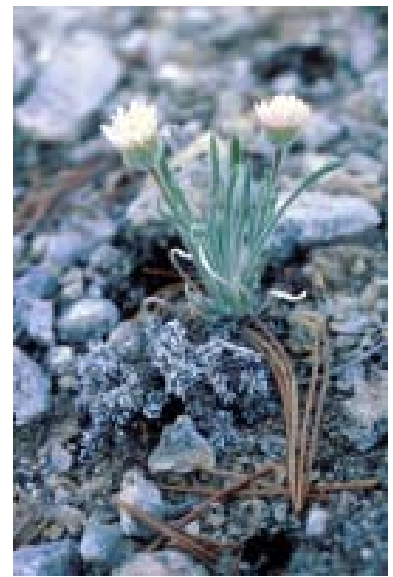

Erigeron parryi, Madison Co.

\section{Erigeron parryi}

Parry's fleabane

BLM Status: none

Heritage Ranking: GNR; (Preliminary State Rank) S2

RANK JUSTIFICATION: Erigeron parryi was first described over 100 years ago based on a single collection made by Frank Tweedy along Grasshopper Creek in Beaverhead County, Montana. Over 50 years ago Arthur Cronquist recognized E. parryi in his monograph of the genus Erigeron (Cronquist 1947). He stated that the species was similar to E. ochroleucus, but the hair of leaves and stems was strikingly different. He hinted that $E$. parryi might be better considered a variety of E. ochroleucus, but since there was still only one collection, he did not formally propose a new nomenclatural combination. Eight years later Cronquist merged E. parryi into E.

ochroleucus, stating that it was a rare form with spreading-hairy herbage (Cronquist 1955). Since that time several additional populations of E. parryi have been located in southwest Montana.

IDENTIFICATION: Parry's fleabane is a taprooted, perennial herb with a simple or branched root crown. The stems are simple or branched and 2-10 cm high. The linear leaves are mainly basal and reduced upward on the stem. Old leaf bases persist on the root crown, giving it a roughened appearance. Hairs of the stem and leaves are ca. $0.5 \mathrm{~mm}$ long, dense, and spreading to widely ascending. One to several flower heads, 8-12 mm wide, are born on branch tips. Involucral bracts are 5-7 mm long, appressed-hairy and often glandular. Rays are white. Disk corollas are yellow and (2.6) 3-3.5 (4.0) mm long. Pappus is of thin bristles. Flowering occurs in June and early July.

Erigeron radicatus has smaller heads and disk flowers. Erigeron ochroleucus has appressed hair on the stems, and sparsely hairy leaves; old leaf bases are generally not apparent on the caudex. Spreading hairs on the stems of E. pumilus are ca. $1 \mathrm{~mm}$ long.

HABITAT: Erigeron parryi occurs on skeletal, limestone-derived soils of ridge crests, slopes and outcrops at 5,200-6,200 (7,000?) ft. Associated vegetation is sparse and dominated by cushion plants, other low forbs and bluebunch wheatgrass. Dominant vegetation in nearby areas with more developed soils is sagebrush steppe or juniper woodland.

ECOLOGY: Erigeron parryi is a small plant and occupies habitats with sparse vegetation suggesting that it is not tolerant of competition.

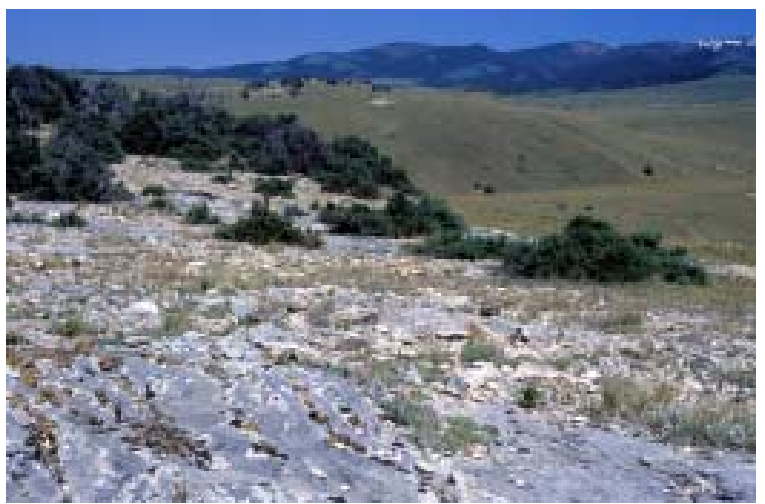

Erigeron parryi habitat, Silver Star, Madison Co.

MANAGEMENT CONSIDERATIONS: At least two populations of Parry's fleabane occur in historic mining districts (Grasshopper Creek, Silver Star). Road construction and other mining-related activities could pose future risks. All known populations are subject to livestock grazing; however, it is unlikely that these small forbs are palatable, and the sparsely vegetated habitat is probably not frequented by livestock. 


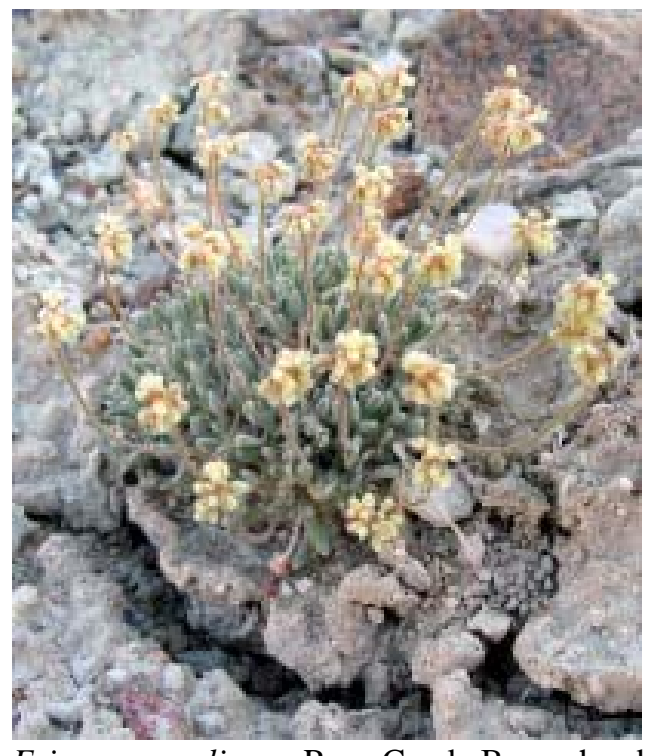

Eriogonum soliceps, Rape Creek, Beaverhead Co.

\section{Eriogonum soliceps \\ Railroad Canyon Wild Buckwheat}

BLM Status: none

Heritage Ranking: G2; S2

RANK JUSTIFICATION: Lemhi buckwheat is a newly described species (Reveal and Bjork, in press) that is confirmed extant at only two locations, one in southern Beaverhead County, Montana and the other in adjacent Lemhi County, Idaho. Herbarium specimens also exist from about 10 other localities southwest Montana. It does not appear to be strongly impacted by cattle grazing, but its habitat would be vulnerable to off-trail vehicles.

IDENTIFICATION: $E$. soliceps is most similar and probably closely related to E. mancum. It differs from this species and all other Eriogonum in a very unusual suite of

characteristics. These are the single involucre per peduncle and lack of bracts (one of only two perennial Eriogonum species known to have these characteristics). It is further distinguished from E. mancum in that the bracteoles are glandular, the perianths have a prominently pustular keel, the peduncles are narrower and less tomentose, and the achene is more pungently textured.

HABITAT: Montana's Rape Creek population occupies gentle southern slopes on coarse alkaline clay derived from calcareous slate. Soils are dry and vegetation is sparse, dominated by Artemisia tridentata ssp. wyomingensis, Phlox muscoides, and Chrysothamnus nauseosus. Associates include Achnatherum hymenoides, Monolepis nuttalliana, Stenotus acaulis, and Carex duriuscula. Other Montana collections are from open slopes and ridgetops with dry stony or shallow soil, often from limestone. Varied associates include Cercocarpus ledifolius, Oxytropis besseyi, O. campestris, Lesquerella alpina, Haplopappus acaulis, Phlox hoodii, Penstemon aridus, Artemisia nova and Ivesia gordonii.

ECOLOGY: Habitats for this plant tend to be

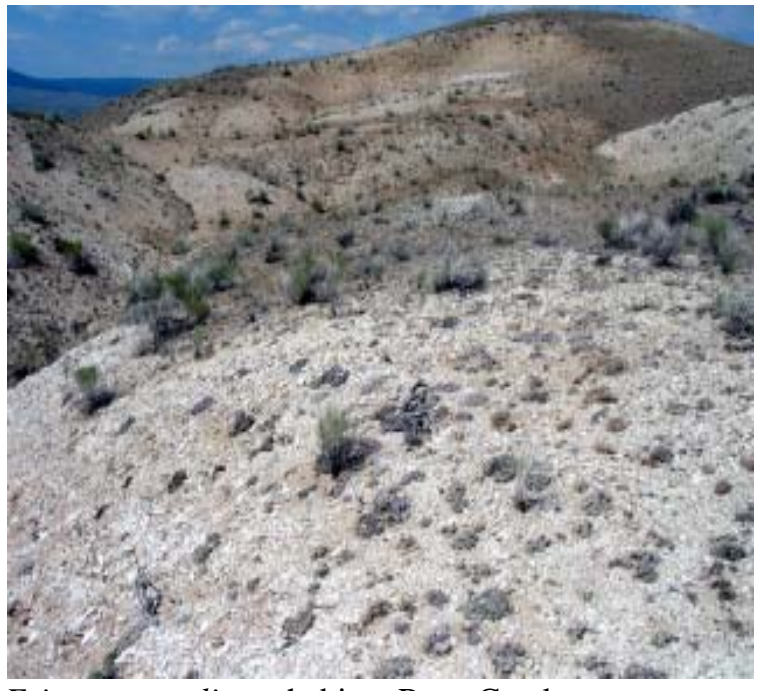

Eriogonum soliceps habitat, Rape Creek, Beaverhead Co. somewhat protected, with vegetation limited to a few species adapted to the poor soils. Like most species of Eriogonum, E. soliceps may readily move into disturbed areas (Reveal \& Bjork 2004).

MANAGEMENT CONSIDERATIONS: No populations have been noted impacted by light cattle grazing or trampling that has been observed at surveyed localities. Exotics weeds were scarce in these habitats and are not currently a threat (Reveal \& Bjork 2004). However, the barren slope habitat could be vulnerable to ATV use. Surveys are needed to determine the full range of this species in Montana as well as the status of historically documented populations and any threats or management needs. 


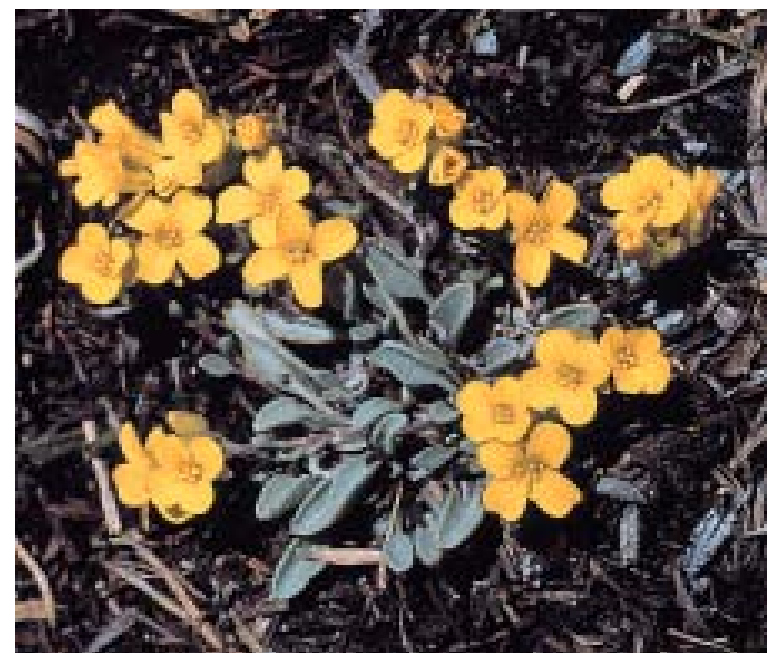

Lesquerella pulchella, Pioneer Mtns., Beaverhead Co.
Lesquerella pulchella

\section{Beautiful bladderpod}

BLM Status: Sensitive

Heritage ranking: G2; S2

RANK JUSTIFICATION: Lesquerella pulchella is a state endemic - occurring only in Montana - and is known only from a few locations, where it is restricted to small areas of sparsely vegetated habitat.

IDENTIFICATION: Beautiful Bladderpod is an herbaceous perennial with unbranched, prostrate to ascending stems arising from a branched rootcrown and taproot. The basal leaves have short petioles and elliptic, entire-margined blades. The alternate stem leaves are smaller and lack petioles. The foliage is covered with branched hairs. Yellow, stalked flowers are borne at the tops of the stems in a narrow inflorescence that elongates as the fruit matures. Each flower has 4 separate petals, 4 separate sepals, and 4 long and 2 short stamens. The flattened, broadly elliptic capsules, or siliques, have a keel on each face. Flowering in June at lower elevations, mid Julyearly August at higher elevations.

It's flattened, nearly circular fruits that have a low ridge on each face, continuous with the style, can identify this species. Fruits of Lesquerella carinata and L. paysonii are longer than broad.

HABITAT: In Montana, this species has been found on gravelly, calcareous soils of sparsely vegetated foothill slopes at elevations ranging from 6200 to 7600 feet. It also occurs in poorly developed, stony soils of subalpine slopes and ridges in the Pioneer and Centennial mountains ranges at 8600-9200 ft. At lower elevations it is associated with openings in mountain mahogany or limber pine woodlands. It also is found in sparse grassland or cushion plant communities at all elevations. This plant is usually associated with calcareous parent material, although it is found on both limestone and associated quartzite in the Centennial Mountains.

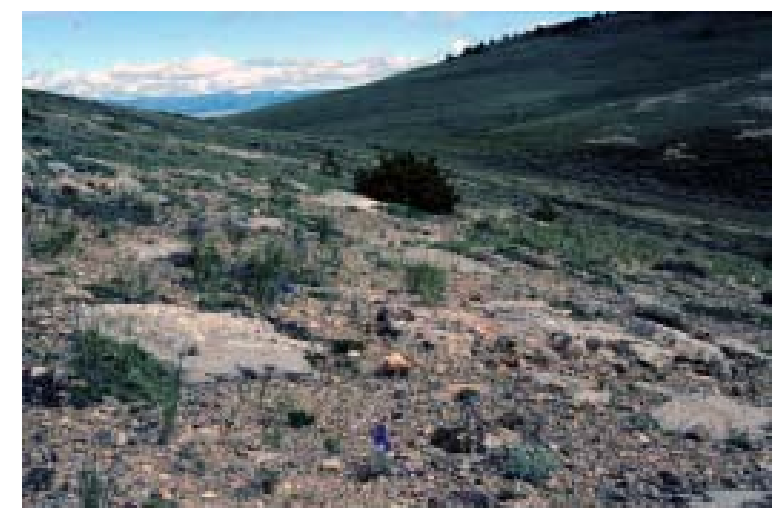

Lesquerella pulchella habitat, Beaverhead Co.

ECOLOGY: This species is a short-lived perennial calciphile that occupies severe, sparsely vegetated habitats with low competition. It can also enter recently-disturbed areas, as in Beaverhead County where small numbers of plants had colonized an open stream bed and an abandoned two-track. The species' natural habitat is subject to frost heave; rodent burrowing activity has also been observed (Heidel and Vanderhorst 1996).

MANAGEMENT CONSIDERATIONS: Beautiful bladderpod occurs in areas with a history of human and natural disturbances. It appears to tolerate and may benefit from disturbances that reduce competition. Invasive weeds may become a threat; the closely related Lesquerella carinata var. languida is being threatened by spotted knapweed (Vanderhorst 1995). Several known populations occur in areas of historic mining activity. 


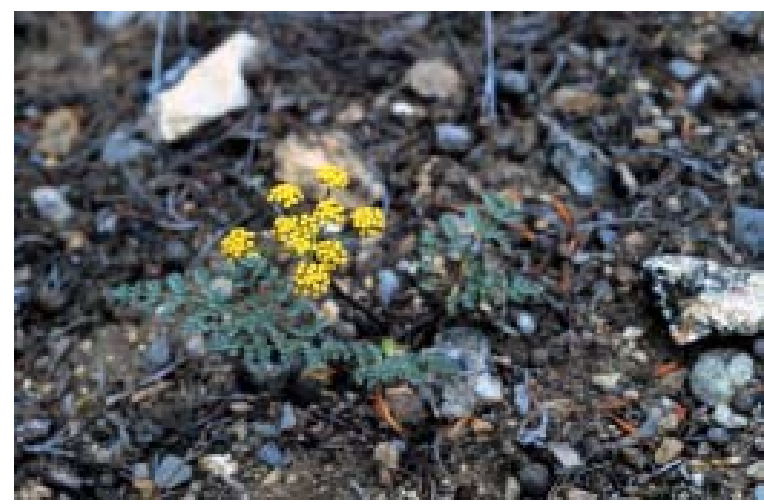

Lomatium attenuatum, Tendoy Mtns., Beaverhead Co.

\title{
Lomatium attenuatum
}

\section{Taper-tip desert-parsley}

\author{
BLM Status: Sensitive \\ Heritage ranking: G3; S2
}

RANK JUSTIFICATION: This species occurs in northwest Wyoming and southwest Montana, with most of its range in Montana. It is known from several locations in Beaverhead and Madison counties. Some populations are vulnerable to impacts from mining activities and noxious weed invasion.

IDENTIFICATION: Lomatium attenuatum is a low herbaceous perennial with 1-2 nearly prostrate leaves on the lower portion of stems that are 7-25 cm tall. Leaves have a petiole that sheaths the stem and broadly lance-shaped blades that are $2-11 \mathrm{~cm}$ long and 3-4 times divided into oblong-linear segments that are 2-5 mm long. Foliage is sandpaper-like. Tiny yellow flowers are borne in 5-8 clusters that are arranged at the ends of 1-5 cm stalks in an open, umbrella-like inflorescence at the top of the stem. Each cluster is subtended by 0-6 pointed, linear, inconspicuous bracts, or involucels. Flowers have 5 separate petals surmounting an ovary that matures into a glabrous, elliptical, flattened fruit that is $5-8 \mathrm{~mm}$ long with corky, ca. $0.5 \mathrm{~mm}$ wide wings on each side borne on stalks 3-10 mm long. Flowering occurs in June and fruits mature in July. The closely related Lomatium cous has conspicuous elliptical involucel bracts and fruit stalks that are only 1-3 mm long.

HABITAT: Taper-tip desert-parsley occurs in scree or dry, gravelly soil of south- or west-facing slopes of mountains, canyons, and foothills (Vanderhorst and Heidel 1998). Subsurface horizons often have clay or silt accumulations, or the gravels are perched on shallow bedrock, ameliorating the droughty surface conditions. Most populations are on limestone, but it has also been found on igneous rock.

In Montana, populations of the species typically occur on dry, unstable, moderate to steep, south- or west-facing slopes of mountains, canyons, and foothills (Vanderhorst and Heidel 1998). Its position on the slope varies with substrate conditions.

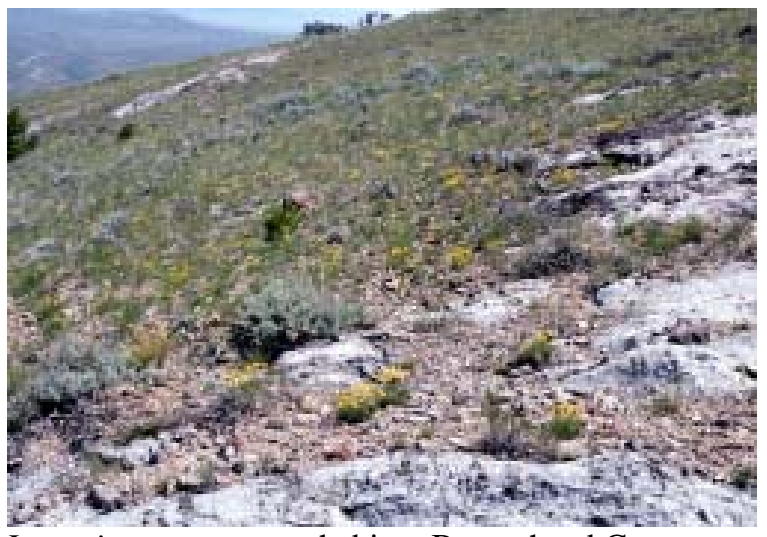
Lomatium attenuatum habitat, Beaverhead Co. The steepest slopes are in canyons, formed from colluvium of overtowering cliffs. Rock outcrops are present at nearly all sites. A few populations (e.g., near Bannack) extend onto nearly level ridgetops with shallow gravels overlying bedrock. Some large populations extend onto more mesic northern exposures and canyon bottoms or toeslopes.

Soils are generally poorly developed lithosols with a high proportion of gravel, commonly referred to as scree (Vanderhorst and Heidel 1998). The substrates are dry, loose, easily disturbed, and have high water infiltration rates with little or no surface runoff. Surface horizons may be sandy, but subsurface horizons often have clay or silt accumulations, or the gravels are perched on shallow bedrock, ameliorating the droughty surface conditions.

Most populations in the state occur on substrates with limestone parent material but it also grows on igneous substrate in the Tendoy Mtns. And Grasshopper Creek and Cold Spring Creek drainages. In Wyoming, this desert-parsley is most often found on volcanics (W. Fertig, personal communication.). 
ECOLOGY: A deep, tough rootstock and short period of active growth allows the species to exploit seasonal subsurface moisture, avoid damage from shifting scree, and remain dormant in dry years. Most populations occur on sites with warm, southerly aspects. By mid summer the exposed scree is dry and hot, and leaves and stems of the species are withered. Year to year climatic fluctuations undoubtedly affect seed production, with apparently greater seed production in cool, wet years. In dry years, high proportions of the plants may remain in a vegetative (non-flowering) state.

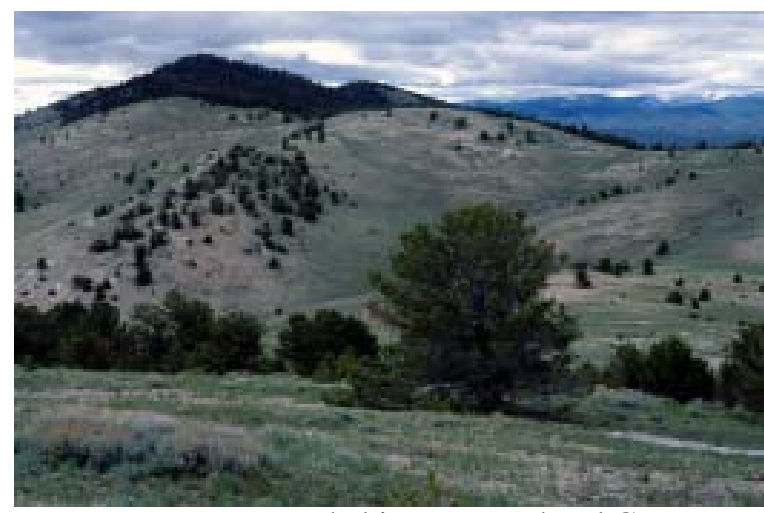

Lomatium attenuatum habitat, Beaverhead Co.
MANAGEMENT CONSIDERATIONS: In general, the rugged topography and lack of forage in taper-tip desert-parsley habitats minimize direct threats from livestock grazing. The species may be affected by livestock grazing insofar as noxious weeds are treated or spread in the course of livestock management. Canyon bottom and canyon toeslope habitats have the greatest incidence of cattle grazing and trailing, and the highest levels of weed infestation. Although logging, road construction and maintenance, and mining may affect species populations, their main impact will be in fostering the encroachment of exotic species, especially spotted knapweed, black medic and common mullein. 


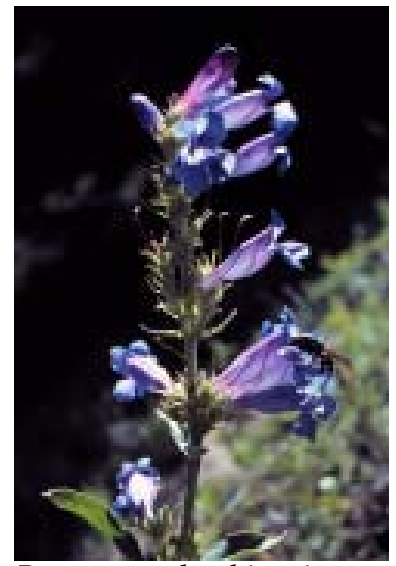

Penstemon lemhiensis, Beaverhead Co.

Penstemon lemhiensis

Lemhi beardtongue

BLM Status: Sensitive

Heritage ranking: G3; S2

RANK JUSTIFICATION: Penstemon lemhiensis is a regional endemic that occurs only in southwest Montana and adjacent Idaho. There are over 50 known populations in Montana, but most have fewer than 100 individuals. Estimates in 1999 placed the total number of individual plants in Montana at about 3000. Its habitat is threatened by the encroachment of spotted knapweed, especially in Ravalli County, and by reduction in wildfire frequency. Mining has also impacted it historically.

IDENTIFICATION: Lemhi Beardtongue is a large perennial, with 1 to several stems up to $70 \mathrm{~cm}$ tall arising from a branched rootstock and a short taproot. The leaves are narrowly lance-shaped and entire-margined. The basal leaves have a petiole and are up to $16 \mathrm{~cm}$ long. The opposite stem leaves lack petioles and are reduced upwards. Herbage is lightly covered with small hairs and occasionally has a thin, bluish wax. The inflorescence consists of clusters of several short-stalked flowers in the axils of the upper leaves. The tubular corolla is flared and two-lipped at the mouth, 25-35 mm long, and bright blue. The lance-shaped calyx segments taper to a long tip, are 7-11 mm long, and have a narrow white margin. The anthers are hairy with short pubescence, and the staminode is glabrous. Flowering from early June-late July, depending on climatic conditions and elevation. Fruits mature and dehisce during August-early September.

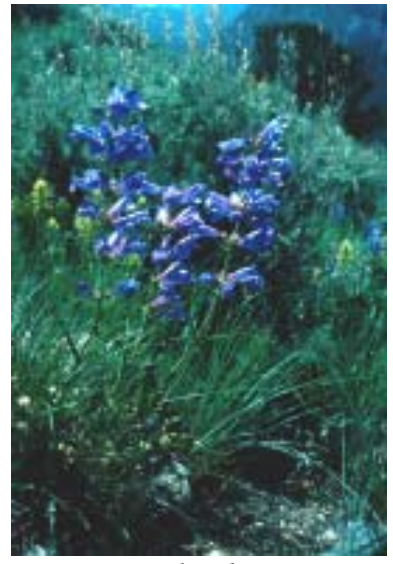

Penstemon lemhiensis

Perennial herb, 3-7 dm tall, with one to several stout stems from a branched caudex; herbage often finely hirtellous-puberulent at least in part; leaves entire, the basal ones clustered, up to $15-20 \mathrm{~cm}$ long and 1-2.5 cm wide, with petiolate, oblanceolate to narrowly elliptic blades; cauline leaves sessile, opposite, mostly lanceolate, up to ca. 10-12 cm long and 1-2 cm wide; inflorescence glabrous, of several to many loose verticillasters, more or less secund in life; calyx 7-11 mm long, the segments lanceolate to narrowly ovate, evidently but not strongly scarious-margined below, tapering to a long-acuminate or subcaudate tip; corolla bright blue to purplish, 25-35 mm long, ca $1.0 \mathrm{~cm}$ wide at the mouth; pollen sacs 1-

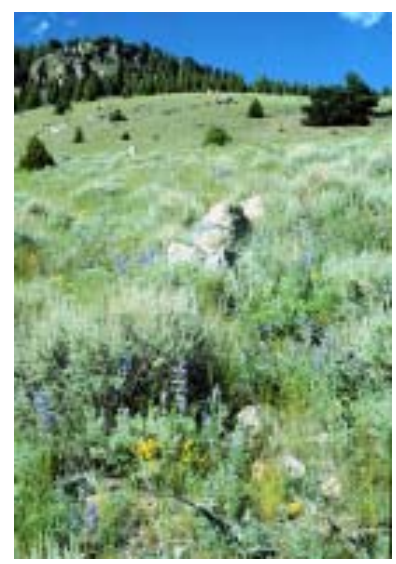

Penstemon lemhiensis habitat, Red Butte, Beaverhead Co.
$3 \mathrm{~mm}$ long, divaricate, evidently dentate ciliate along the sutures, pubescent near the connective and on side away from dehiscence; staminode glabrous; capsules ca 10-15 mm long; seeds ca 2-3 mm long (Shelly 1987).

Penstemon cyaneus is very similar but has sepals that are rounded at the tip and nearly as broad as long. Penstemon cyananthus has smaller flowers only $15-25 \mathrm{~mm}$ long.

HABITAT: In Montana, Penstemon lemhiensis occurs on moderate to steep, east- to southwest-facing slopes, often on open soils. In Beaverhead County, it typically grows below or near the lower extent of Douglas fir and/or Lodgepole pine forest. Associated vegetation is typically dominated by big sagebrush and bunchgrasses, including western wheatgrass and Idaho fescue. Within these habitats, Lemhi beardtongue prefers areas that are more sparsely vegetated (Shelly 1990). In the northeastern Pioneer Mountains, it inhabits forbdominated openings in lodgepole pine and to a lesser extent Douglas fir forest;

Appendix B - 21 
big sage is typically not present, and prominent forbs include Astragalus miser, Pedicularis contorta and Townsendia parryi.

The species is not restricted to any particular geological substrate; it has been found on granitic soils, as well as limestone and other sedimentary substrates. Soils are often very gravelly, however soil texture is highly variable and ranges from sand to fine clay. Field surveys from 1986-1989 indicate that it is most commonly found on gravelly loams. At some sites the populations can occur partially or entirely on roadbanks.

ECOLOGY: Lemhi beardtongue has some degree of adaptation to natural disturbance, as evidenced by its preference for more open habitats, such as rock outcrops and steep rocky slopes with natural soil slippage (Shelly 1990). This adaptation is even clearer where plants have colonized roadbanks.

Studies have shown that seed germination and recruitment are the most critical life history stages (Heidel and Shelly 2001). In general, both flowering and germination are higher in cool, wet springs and early summers, and are correlated with April-June mean maximum monthly temperature and net precipitation in the same period. Mortality of established plants is highest in hot, dry years (Heidel and Shelly 2001).

MANAGEMENT CONSIDERATIONS: Monitoring studies on National Forest and BLM Lands in southwest Montana have documented sharp declines in some of the largest populations east of the Continental Divide (Shelly 1990;

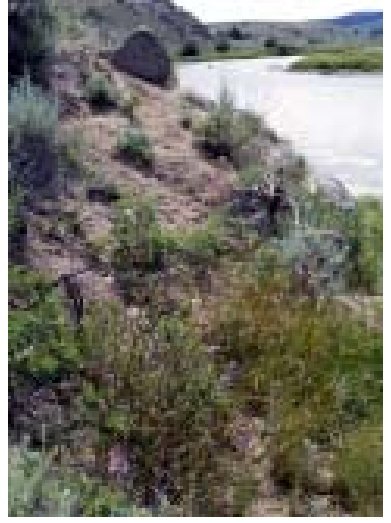

Penstemon lemhiensis

habitat, Sawlog Creek, Big Hole River Achuff 1992). One relatively small monitored population was restricted to roadcut habitat and was similarly in decline. Continued declines were projected in the absence of seed germination and recruitment at part or all of the other 3 sites. Waxing and waning of populations is expected for native ruderal species such as Penstemon lemhiensis.

Fire suppression has been suggested as a factor in the rangewide decline of Lemhi beardtongue (Moseley et al. 1990). It is thought to increase under certain fire regimes, based on qualitative observations after a wildfire in Salmon National Forest and monitoring of a prescribed burn in Big Hole National Monument, where it increased a decade after the burn but disappeared from an adjoining untreated area (Heidel and Shelly 1997). Another monitoring study at Badger Pass found that recruitment increased dramatically after fire treatment, consistent with the tendency of fire-adapted species to show recruitment from seedbanks when fire removes accumulated litter and reduces competition. Based on these studies, prescribed burning has been recommended where Lemhi beardtongue occupies deep-soil rangeland habitats east of the Continental Divide, which are prone to increasing density of Artemisia tridentata in the absence of fire (Heidel and Shelly 2001).

Spotted knapweed is a widespread invader in this species' habitat, particularly west of the Continental Divide. Where Lemhi beardtongue occurs in the Bitterroot National Forest, management is problematic because of the high potential for noxious weeds to expand after fire (Heidel and Shelly 2001). Although herbicides can be used to control invasives, their effect on pollinators of the Lemhi beardtongue is not known. It is an obligate out-crosser, primarily dependent on insect pollination, and relatively small, isolated populations may already be at a disadvantage in their ability to attract effective pollinators (Shelly 1990). Spotted knapweed has not yet invaded populations in Beaverhead and Silver Bow Counties, though it has been observed in nearby areas where it can still be controlled without direct impact to the species. Grazing exist throughout much of the species' range in southwestern Montana, and monitoring transects have been established to assess its effect on populations. The habitat of Lemhi beardtongue was historically impacted by mining at some locations, and renewed gold mining activity could pose a future threat (Shelly 1990). 


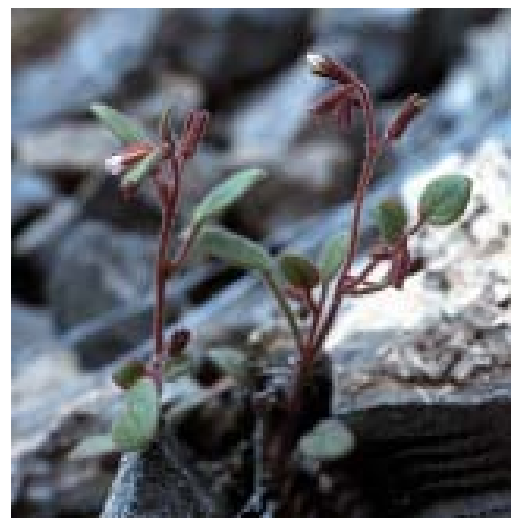

Phacelia incana, Tendoy Mtns., Beaverhead Co.

Phacelia incana

\section{Hoary Phacelia}

BLM Status: Watch

Heritage Ranking: G3G4; S2

RANK JUSTIFICATION: Phacelia incana occurs in Idaho, Nevada, Utah, Colorado and Montana. In Montana it is known from fewer than ten populations in Beaverhead County. It is difficult to estimate the size of populations because the plant is an annual, and seed germination varies greatly with climate. Habitat is probably not threatened by anthropogenic sources.

IDENTIFICATION: Hoary phacelia is a small annual with erect, branched stems up to $10 \mathrm{~cm}$ high. The alternate leaves have well developed petioles and broadly elliptic, untoothed blades that are 3-15 mm long. Foliage is covered with spreading, often gland-tipped hairs. Short-stalked, white to bluish flowers are borne in sparse, narrow, curved 1-sided spikes that unwind as they mature. Each flower has 5 strapshaped sepals 3-4 mm long and a 5-lobed tubular corolla that is barely longer than the calyx. Stamens are included within the floral tube. The fruit is a many-seeded capsule. Other members of the genus Phacelia have lobed or divided leaves. Species of Cryptantha have bristly, hairy foliage and the foliage of Myosotis spp. lacks the gland-tipped hairs.

HABITAT: Hoary Phacelia is found in stony, limestonederived soil on steep talus slopes in the foothills. Associated vegetation is mountain mahogany (Cercocarpus ledifolius) with a sparse ground layer dominated by other annuals such as Descurainia richarddsonii, Collinsia parviflora and Cryptantha watsonii. Oryzopsis hymenoides and Agropyron spicatum are uncommon perennial grasses.

ECOLOGY: Phacelia incana is a small annual that completes its life cycle quickly. It occurs in sparsely vegetated, unstable habitats and probably benefits from disturbance. In dry years populations are composed primarily of seeds in the seed bank and are difficult to detect.

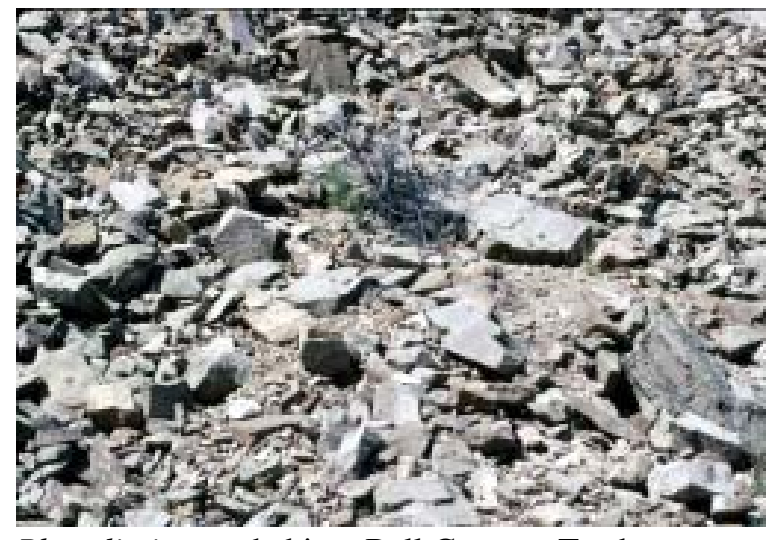

Phacelia incana habitat, Bell Canyon, Tendoy

Mtns., Beaverhead Co.

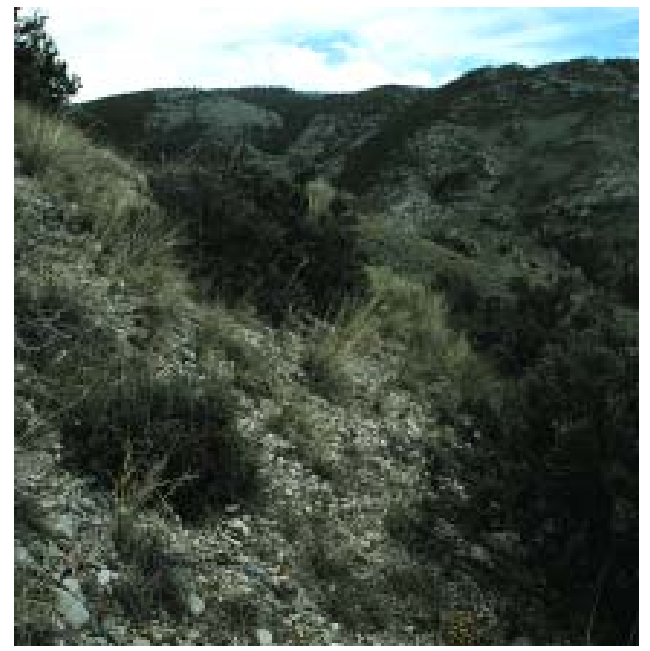

Phacelia incana habitat, Bannack State Park, Beaverhead Co.

MANAGEMENT CONSIDERATIONS: Mule deer usually graze its habitat, and although livestock also have access, the steep slopes and dense, low canopy deter most cattle. Hoary phacelia is an annual, so grazing or moderate disturbance of any kind probably has a positive effect on population growth. 


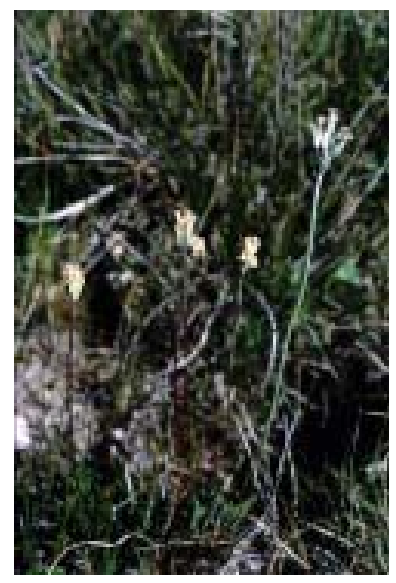

Primula alcalina (left) and P. incana (right), Cabin Creek, Beaverhead Co.

Primula alcalina

Idaho primrose

BLM Status: Watch

Heritage ranking: G1; S1

RANK JUSTIFICATION: Primula alcalina is a regional endemic, with only one occurrence documented as extant in Montana. Its wetland habitat is vulnerable to hydrologic alterations.

IDENTIFICATION: Idaho primrose is a fibrous-rooted perennial with a basal rosette of leaves and a leafless flower stem. Leaves are 1-4 cm long, narrowly elliptic with wavy or toothed margins, and gradually tapered to the short, winged petiole. The leaf surface may have white flake-like farina when young but become mostly glabrous with age. The whitish-green flower stem is 6.5-24 cm long with a 3-10 flowered, simple umbel at the apex. Bracts of the inflorescence are lanceolate, covered with white farina and 4-7 mm long. Erect flowers have a 5-lobed, white farinose calyx 4-6.5 mm long with pointed tips. The white corolla has a 4-7 mm long tube with spreading lobes that are 3-5 mm long and deeply bilobed. The fruit is a capsule.

Primula alcalina is similar to the closely related P. incana. However, flowers of Primula incana are lavender and larger than those of P. alcalina. Stems of Primula alcalina are reddish, while those of $P$. incana are whitish. Leaves of Primula alcalina are nearly glabrous below, but those of $P$. incana are densely covered with white flake-like hairs. Their flowering periods overlap, but on average, Primula alcalina flowers earlier.

HABITAT: Idaho primrose is known from eastcentral Idaho and adjacent Montana. Six populations have been documented in Clark, Custer and Lemhi counties, Idaho, and one in Beaverhead County, Montana. A second Beaverhead County population, observed at Monida in 1936, is presumed extinct. Primula alcalina is found in moist to wet alkaline meadows associated with headwaters streams at 6,300 to 7,200 ft. in elevation. The soil surface often displays hummock-hollow topography. Soils in the meadows are alluvial, alkaline, fine- textured, light-colored, and derived from outwash from the predominantly carbonate rocks of the Beaverhead, Lemhi, and Lost River

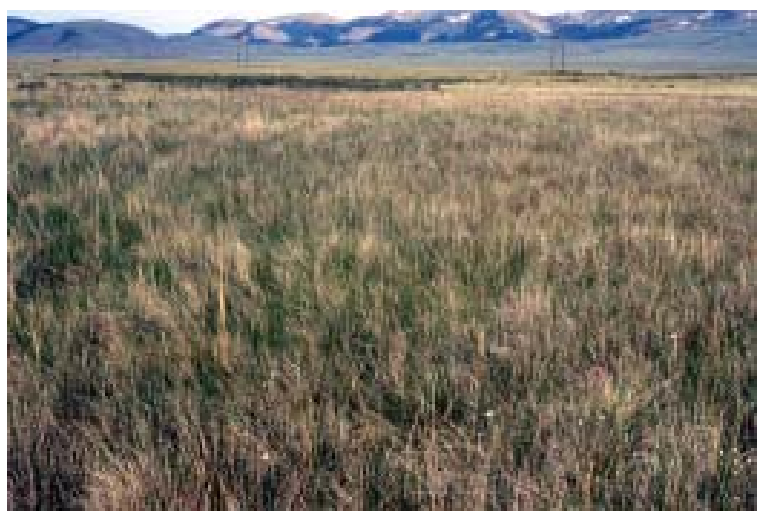

Primula alcalina habitat, Cabin Creek, Beaverhead Co. ranges. Soil pH was found to average 8.9-9.6 at study sites in Idaho (Moseley 1995). Commonly associated species include Juncus balticus, Deschampsia cespitosa, Carex scirpoidea, Carex nebrascensis, Carex praegracilis, Agropyron trachycaulum, Muhlenbergia richarsonis, Senecio debilis, Crepis runcinata, Triglochin maritima, Dodecatheon pulchellum and Thalictrum alpinum. Potentilla fruticosa is common at some sites, primarily those with hummocks. Primula alcalina occurs in the lowest topographic positions in the meadows, where the subirrigated soil is saturated to the surface throughout the growing season. Plants occur on low, relatively level benches immediately adjacent to creeks and spring heads, often on the inside of meander loops, and also on low benches with hummocky topography. Primula alcalina is often most abundant on the tops and sides of hummocks where the density of graminoids is lowest. 
ECOLOGY: Idaho primrose appears restricted to wet meadow habitats associated with relatively stable water tables. Associated streams have a fairly constant water flow; i.e., permanent flows with little flooding in spring (Moseley 1989; Mansfield and Miyasaki 1993). Soils remain moist to saturated throughout the growing season, but there is little or no inundation. On a very local scale, the density of Primula alcalina is negatively associated with the abundance of rhizomatous graminoids such as Juncus balticus and Carex nebrascensis. Thus, Idaho primrose is often most abundant on the tops and sides of hummocks where the density of graminoids is lowest (Moseley 1989).

MANAGEMENT CONSIDERATIONS: The one known Montana population of Idaho primrose lies both on private land and on public land managed by BLM. Most of the potential habitat on private land has not been surveyed. The entire known Primula alcalina habitat at this site is subject to cattle grazing. Many of the permanent streams providing habitat for Primula alcalina have diversions for irrigation. Withdrawal of water during summer months may lower stream levels and the associated riparian water table. Chronic dewatering will result in the loss of wetland habitat and a decline of Idaho primrose habitat. Beavers were present on these streams in recent years and probably were common before Europeans entered the area. The presence of beavers often results in an increase in wetland habitat through a raising of the water table and trapping of silt behind impoundments. The long-term increase of wetland habitat might benefit Primula alcalina.

Livestock congregate in the vicinity of wetlands in summer for the lush, succulent vegetation and proximity to water. The effects of livestock grazing on Idaho primrose are both positive and negative. Since its leaves are all low to the ground, herbivory by livestock can prevent seed production but will not kill the plant or remove significant photosynthetic tissue. Grazing can also be positive by partially removing the overtopping canopy of grasses and sedges, allowing more light to reach Primula alcalina rosettes. Livestock grazing can also indirectly affect wetland vegetation by altering hydrologic regimes. Cattle trampling may benefit many of the rare species by creating mesic microhabitats on the tops and sides of the hummocks. Hummock habitats are moist without being wet and are more open than wetter micro-habitats dominated by sedges and rushes. Muir and Moseley (1994) found no significant association between grazing pressure and the abundance of Idaho primrose. Lindborg and Ehrlen (2002) found grazing is positively associated with the persistence of Primula farinosa, a closely related European species.

Livestock grazing may also impact the habitat of Primula alcalina by altering hydrology. Grazing in the uplands can reduce vegetal cover, thereby increasing runoff, flash flooding and channel downcutting. The lowered water table that accompanies downcutting causes a diminution of wetland habitat. Loss of wetlands would likely result in population declines. This impact can be minimized by restricting livestock grazing to the later part of the summer in as many years as possible to help reduce trampling and grazing of herbaceous vegetation on stream banks. Where needed, grazing can also be managed to restore grass cover in the uplands. Restoration of willows (Salix planifolia, S. boothii, S. geyeriana) would be beneficial along Cabin and perhaps Simpson creeks. If willows can be reestablished, beavers may colonize and help restore wetland habitat. Stream reaches with downcutting could be dammed to raise the local water table. 


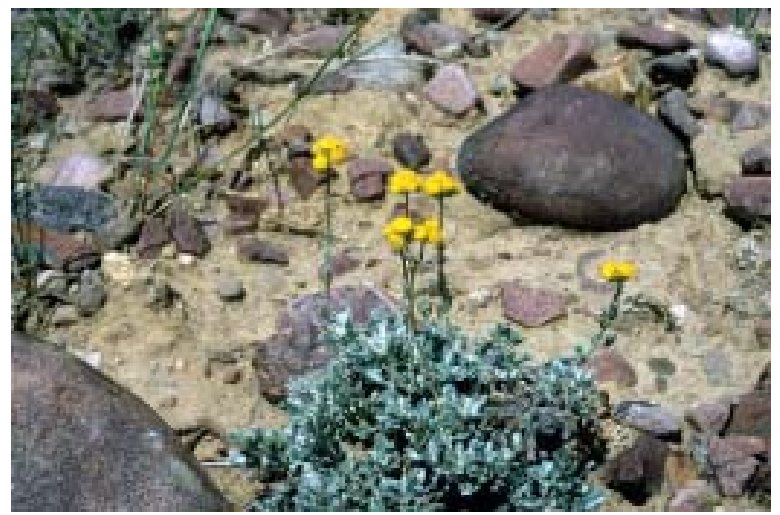

Sphaeromeria argentea, Beaverhead Co.
Sphaeromeria argentea

\section{Chicken Sage}

BLM Status: Sensitive

Heritage Ranking: G3G4; S2

RANK JUSTIFICATION: Sphaeromeria argentea occurs in east-central Idaho and adjacent Beaverhead County, Montana with disjunct populations in Nevada as well as southwest Wyoming and adjacent Colorado. There are nearly 20 known locations south of Dillon; many populations are sparse but spread over large areas, so population estimates are difficult. All known populations are subject to livestock grazing; however chicken sage is aromatic and most likely unpalatable to cattle.

IDENTIFICATION: Chicken sage is a mat-forming perennial herb or subshrub with multiple flowering shoots that are $5-20 \mathrm{~cm}$ high and many shorter, sterile shoots. The alternate leaves are up to $15 \mathrm{~mm}$ long and are narrowly fanshaped and usually 3-lobed at their tip. They are aromatic and densely covered with appressed, gray hair. Several short-stalked, globose flower heads are borne at the stem tips. Each head has numerous disk flowers and 2-3 series of overlapping, membranous-margined involucral bracts that are 3-4 mm high. There are no ray flowers, and the achenes lack a pappus.

Chicken sage resembles a small, low-growing sagebrush plant (Artemisia spp.) but has fewer heads per stem. The flower heads are larger and tightly clustered, and the basal leaves are lobed nearly to the base.

HABITAT: Chicken sage generally grows on shallow limestone-derived soil of sagebrush steppe in the valley and foothill zones. Associated vegetation is quite variable, but all habitats are arid, alkaline and have low vegetation competition.

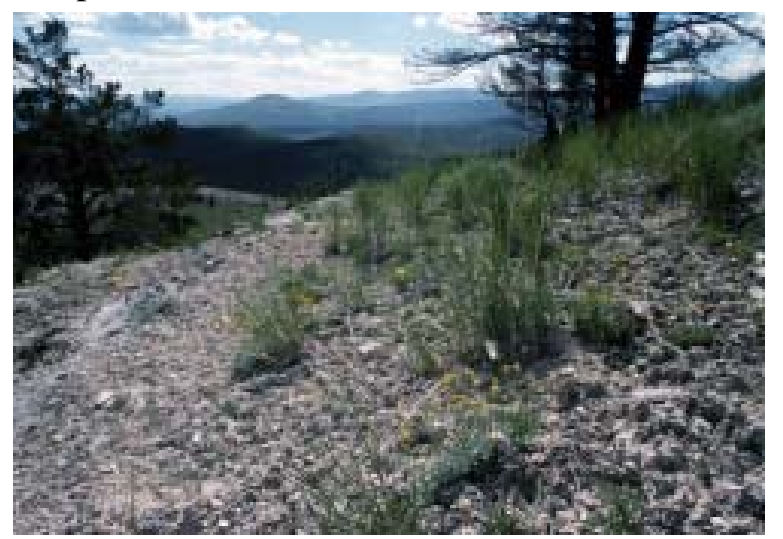

Sphaeromeria argentea habitat, Bannack, Beaverhead Co.

In the Grasshopper drainage of Beaverhead County, it occurs in two distinct habitats: 1) localized sandy clay pockets of sagebrush steppe dominated by Artemisia arbuscula/Agropyron spicatum, and 2) limestone outcrop ridgetops and slopes covered by dry bunchgrass communities of Agropyron spicatum and cushion plants, at the most sparsely-vegetated local extreme (Heidel and Vanderhorst 1996). In the Rocky Hills and near Bannack, chicken sage grows in openings of a limber pine (Pinus flexilis) and mountain mahogany (Cercocarpus ledifolius) community. Subdominant grasses include Elymus spicatus and Koeleria macrantha. Associated forbs include Erigeron compositus, Erigeron tweedyi,

Haplopappus acaulis, Ivesia gordonii, Penstemon aridus and Penstemon eriantherus, all of which are characteristic of limestone outcrops.

In the Sage Creek drainage, this species has been found in heavy soil of eroding slopes at about 6300 feet elevation; common associates include Haplopappus acaulis and Erigeron tweedyi (Lesica

Appendix B - 26 
and Vanderhorst 1995). It also occurs in this area on dry, rocky bunchgrass slopes not confined to limestone parent material; common associates include Ceratoides lanatus, Selaginella densa, Antennaria microphylla, Astragalus miser, Haplopappus acaulis, Eriogonum mancum, and Erigeron caespitosus. In the drainage of upper Big Sheep Creek, the habitat is an unusual alkaline bottomland community dominated by low sagebrush (Artemisia arbuscula) and greasewood (Sarcobatus vermiculatus).

ECOLOGY: Chicken sage is a long-lived perennial. Populations are generally sparse but often widespread. It occurs in many different common habitats but occupies only a small proportion of the apparently available habitat. Chicken sage is aromatic like closely related species of Artemisia and Tanacetum.

MANAGEMENT CONSIDERATIONS: The species is an aromatic sub-shrub that grows low to the ground and is likely unpalatable or not affected much by livestock grazing (Vanderhorst and Lesica 1994). Where it grows on steep, rocky slopes, it is not very vulnerable to mechanical disturbance, such as trampling by cattle. However, bottomland habitats are more vulnerable. Grazing, mining and other activities may promote the spread of exotic species such as Bromus tectorum, Centaurea maculosa and Melilotus spp. The species is widespread in southern Beaverhead County, although never abundant. Some populations occur in historic mining districts, and could be threatened by future mining activities. However,

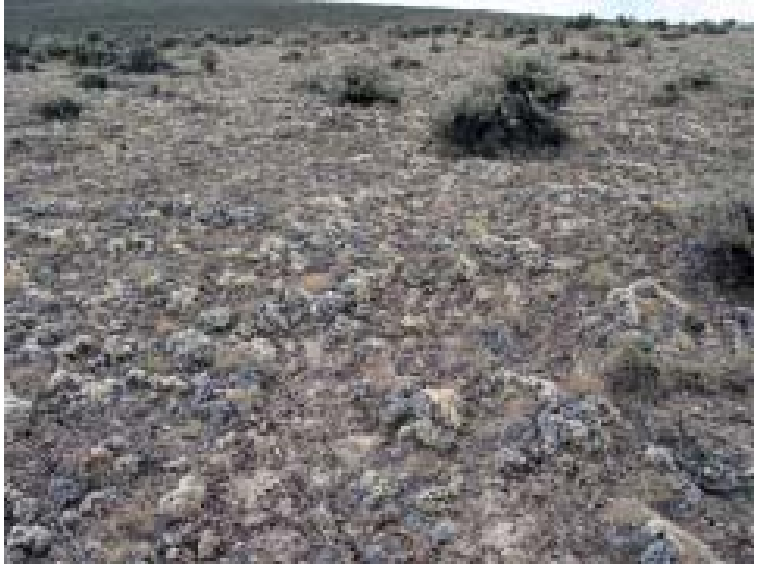

Sphaeromeria argentea habitat, Beaverhead Co. many of the known populations face no anthropogenic threats. 


\section{Thelypodium paniculatum}

\section{Northwestern thelypody}

\section{BLM Status: Sensitive}

Heritage ranking: G2; SH

RANK JUSTIFICATION: Thelypodium paniculatum has a range that includes southwest Montana, adjacent Idaho, western Wyoming and adjacent Colorado. In Montana it is known only from an 1899 collection in Beaverhead County, although Dorn (1984) also reports it for Madison County.

IDENTIFICATION: Northwestern thelypody is an herbaceous biennial or short-lived perennial with solitary, simple or branched stems that are 3-7 dm high and arising from a taproot. Its lower leaves are 4$10 \mathrm{~cm}$ long and have petioles and narrowly lance-shaped, entire-margined blades. The upper stem leaves are 2-6 cm long and lance-shaped with basal wings that clasp the stem. Foliage is glabrous and has a thin, waxy coating. Flowers are borne on ascending stalks in cylindric inflorescences that are up to $35 \mathrm{~cm}$ long when mature. Each flower has 4 separate sepals that are 5-8 mm long, 4 separate, lavender petals that are 10-16 mm long and 2-6 mm wide, and 4 long and 2 short stamens. The ascending, straight, cylindrical capsules, or siliques, are 25-40 mm long and 1.3-2.3 mm wide. Flowering occurs in June.

Thelypodium sagittatum is very similar but has petals that are only 1-3 mm wide and fruits that are less than $1.3 \mathrm{~mm}$ wide.

HABITAT: Thelypodium paniculatum grows in wet sedge meadows where the water level may cover basal portions of the plant. It appears to favor meadows and stream bottoms that remain wet for most of the season. Two localities in Yellowstone National Park are in very wet sedge meadows. In contrast, Thelypodium sagittatum grows in alkaline meadows that are often dry, but may be wet in the early part of the season (Al-Shehbaz 1973).

ECOLOGY: Northwestern thelypody has lightweight seeds that are probably very easily distributed (AlShehbaz 1973). Wind may be an important factor in their dispersal in open habitats such as deserts, flats and open slopes, but the action of rain wash is perhaps equally if not more important (Al-Shehbaz 1973). Flooding is likely to be a major means of seed dispersal for species growing along streamsides, creek beds and river banks, and may also be important for those found in meadows (Al-Shehbaz 1973).

MANAGEMENT CONSIDERATIONS: Based on available habitat information, this species could be vulnerable to riparian grazing or hydrologic changes. 


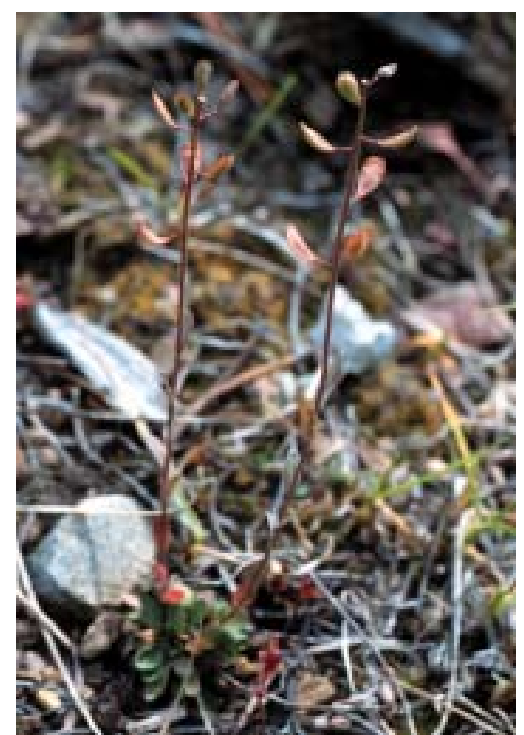

Thalspi parviflorum, Moosetown, Silver Bow Co.

\section{Small-flowered pennycress}

BLM Status: none

Heritage Ranking: G3; S2

RANK JUSTIFICATION: Thlaspi parviflorum is a regional endemic, known in Montana from several southwestern counties. It is a small, short-lived plant that likely requires disturbance to maintain its habitat.

IDENTIFICATION: Small-flowered pennycress is a glabrous, glaucous, taprooted biennial or short-lived perennial 1-3 dm tall and often branched in the upper half. Basal leaves are 5-15 mm long with a slender petiole and narrowly elliptic blades that are sometimes toothed. The stem leaves are sessile and clasp the stem. Flowers are borne on short, nearly horizontal stalks in a narrow inflorescence that elongates as the fruits mature. The four green sepals are 1-1.5 mm

long, and the four white petals are 2-3 mm long. Flattened fruits are oblanceolate and 5-7 mm long with a style up to $0.5 \mathrm{~mm}$ long. Thlaspi parviflorum is similar to the more common T. montanum var. fendleri. However, the latter species has longer sepals and petals, and the style in fruit is at least $1 \mathrm{~mm}$ long.

HABITAT: Thlaspi parviflorum is found in northcentral Wyoming, east-central Idaho and southwest Montana. In Montana it is known from Beaverhead, Carbon, Madison, Park and Silver Bow counties, where it is found in mid-elevation grasslands to alpine turf from about 6,500 to $10,000 \mathrm{ft}$ in elevation. It is most frequently in sagebrush steppe dominated by Artemisia tridentate ssp. vaseyana and Festuca idahoensis. Several moisture-loving species, such as Juncus balticus and Potentilla fruticosa, are often present in these habitats. Small-flowered pennycress has also been found occasionally in alpine turf communities,

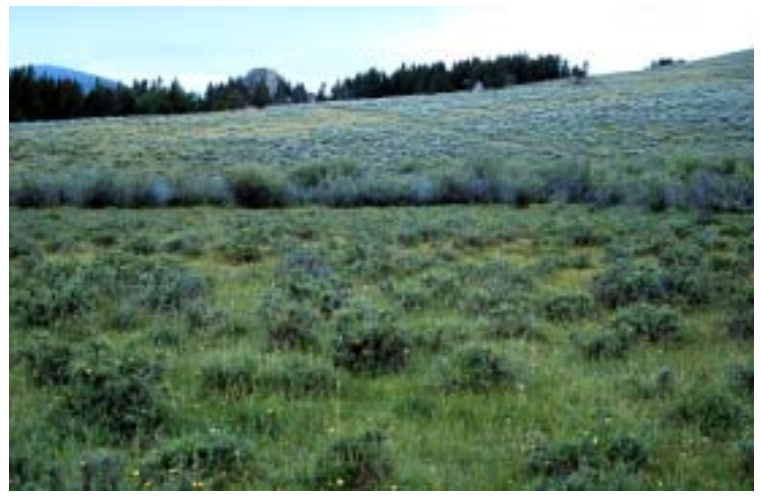

Thalspi parviflorum habitat, Silver Bow Co. ranging from moist habitats dominated by Deschampsia cespitosa and Carex scirpoidea to drier sites supporting Carex elynoides.

ECOLOGY: Thlaspi parviflorum is a short-lived plant, smaller than the dominant species in most of the habitats where it occurs. It flowers early and is often found in open microsites between shrubs or bunchgrasses. Given its growth form and habitat, it may be expected to respond positively to disturbances such as moderate grazing or fire that opens the canopy.

MANAGEMENT CONSIDERATIONS: Fire and grazing are two important forces affecting Smallflowered pennycress habitat. Fire disturbance reduces competition from sagebrush and large bunchgrasses and likely enhances population viability for Thlaspi parviflorum. Livestock grazing generally favors broad-leaved forbs at the expense of graminoids. Small-flowered pennycress is a very small plant likely to benefit from removal of dominant grass canopy. Nearly all known Montana populations of Thlaspi parviflorum are on public land, primarily managed by the U.S. Forest Service. Most of these sites are subject to livestock grazing. 


\section{Appendix C. Landscapes of Conservation Significance - DETAILED DESCRIPTIONS}

(NOTE THAT MAPS ARE INTENDED TO SHOW THE GENERAL LOCATION AND EXTENT OF AREAS DISCUSSED, AND ARE NOT INTENDED AS PRECISE BOUNDARY DELINEATIONS) 


\section{BIG SHEEP CREEK BASIN}

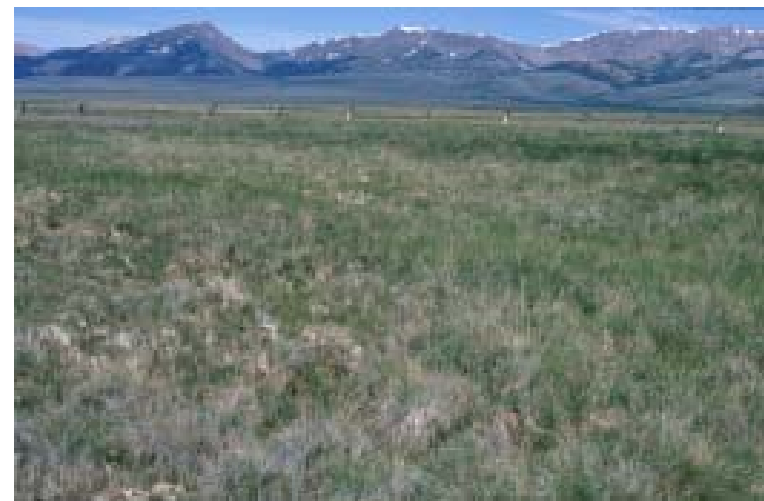

Primula alcalina habitat Cabin Creek, Beaverhead Co.

\section{Description}

Big Sheep Creek Basin is a high valley between the

Beaverhead and Tendoy mountain ranges in southern Beaverhead County. It is bounded on the west by the Beaverhead Range and on the east by the Tendoy Mountains and includes the headwaters of Big Sheep Creek, including Cabin, Meadow, Nicholia and Deadman creeks, below 8,500 ft. Elevations range from 6,750 ft at the confluence of Deadman and Big Sheep creeks to 8,500 ft (approximate lower treeline) on the slopes of the surrounding mountains. Most of the site is near-level valley floor dissected by perennial and intermittent streams. Broad areas along streams are

subirrigated and cut for hay in wet years. Nearly all of the area is subject to livestock grazing and big game hunting, in season.

\section{Geology and soil}

The Tendoy and Beaverhead ranges are composed primarily of Paleozoic and Mesozoic sedimentary formations tilted and uplifted along faults. The predominant parent material in the mountains surrounding the Big Sheep Creek Basin is Paleozoic Madison limestone. Exposures of Madison limestone form cliffs and talus slopes in canyons near the confluence of Cabin, Deadman and Big Sheep creeks where they cut through the west side of the Tendoy Range. Gentle, hilly, glacially-formed terrain with drumlins and small ponds is found in small areas in the foothills of the Beaverhead Range near the head of Simpson and Cottonwood creeks. The basin proper is a continuous series of alluvial fans emanating from the east front of Beaverhead Range and drained by a dendritic pattern of small creeks that join to form Big Sheep Creek at the east end of the basin.

The alluvial soils of the basin are silty to clayey and calcareous with abundant small stones. They are often subirrigated along permanent streams. These alluvial soils are often poorly developed with sparse vegetation due, in part, to the cold, dry climate. Evidence of sheet erosion is commonly observed. Soils of the foothills are calcareous, loamy to silty and often stony. Those associated with limestone outcrops are generally shallow.

\section{Vegetation}

Alluvial soils in uplands of the basin proper support sagebrush steppe dominated by Wyoming big sagebrush (Artemisia tridentata ssp. wyomingensis) with a ground layer dominated by bluebunch wheatgrass (Agropyron spicatum), western wheatgrass (Agropyron smithii) and Sandberg bluegrass (Poa secunda). Lower sites with heavier soils often support low sagebrush steppe dominated by Artemisia arbuscula longiloba with a ground layer of western wheatgrass or Idaho fescue (Festuca idahoensis) on slightly steeper inclines (Cooper et al. 1995).

Dominant vegetation of the foothills is sagebrush steppe dominated by mountain big sagebrush (Artemisia tridentata ssp. vaseyana) and Idaho fescue. Low sagebrush steppe dominated by Artemisia arbuscula arbuscula, bluebunch wheatgrass and spike fescue (Leucopoa kingii) may occur on warm slopes with skeletal limestone soils. Limestone slopes may support dry Douglas-fir (Pseudotsuga menziesii) forest on cool slopes and limber pine (Pinus flexilis) and/or mountain mahogany

(Cercocarpus ledifolius) woodland near lower timberline (Cooper et al. 1995).

Low sagebrush communities, Artemisia arbuscula arbuscula/Agropyron spicatum, Artemisia arbuscula longiloba/Agropyron smithii and Artemisia arbuscula longiloba/Festuca idahoensis are rare in Montana, found only in Beaverhead County. The latter two community types are globally rare. 


\section{BIG SHEEP CREEK BASIN}

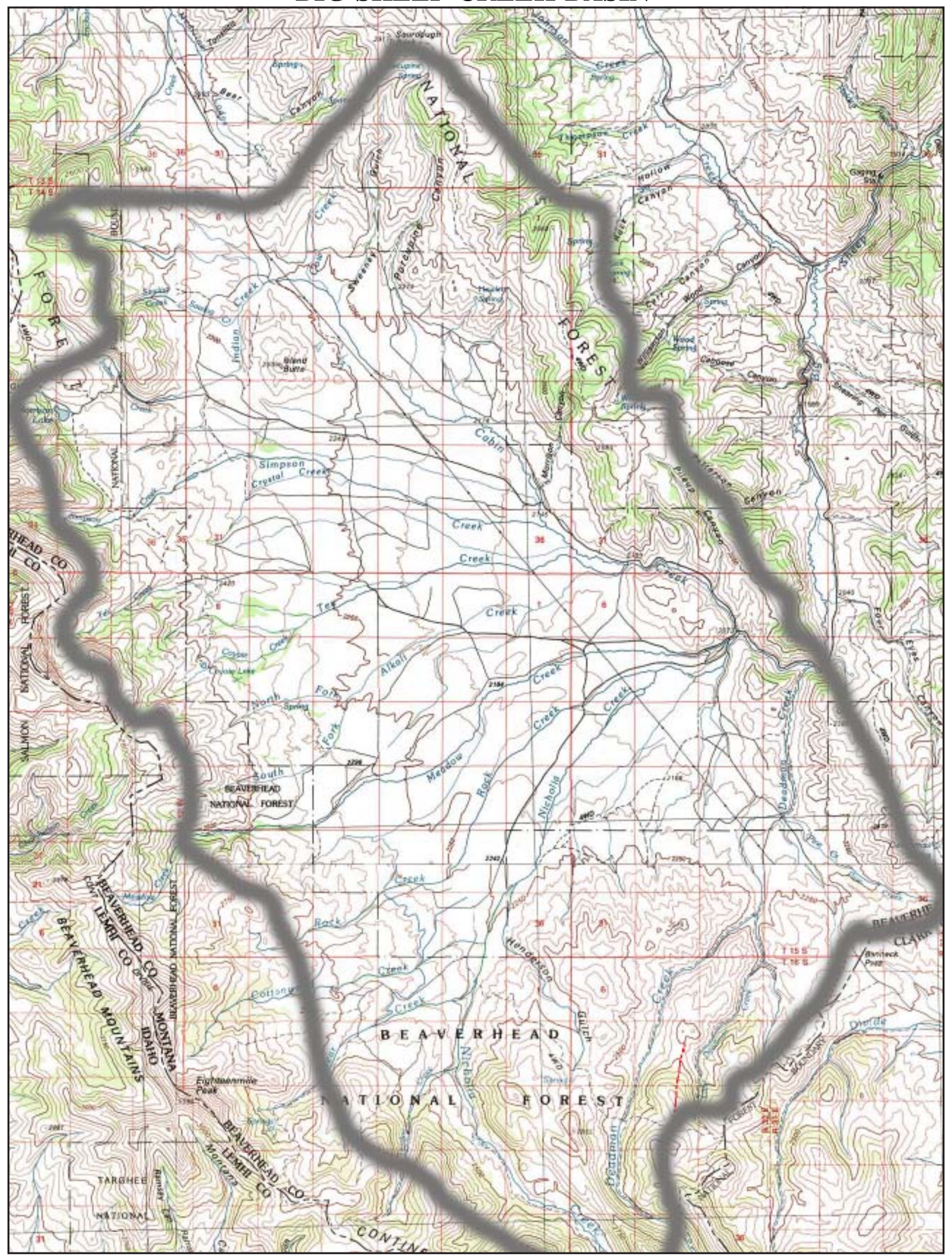

Appendix C - 2 
Wetlands are often associated with permanent streams, springs and glacial ponds. Habitats with microtopography such as hummocks, support shrubby cinquefoil (Potentilla fruticosa) with a ground layer dominated by Baltic rush (Juncus balticus), tufted hairgrass (Deschampsia cespitosa), Nebraska sedge (Carex nebrascensis), Carex scirpoidea and numerous forbs. Similar communities without shrubby cinquefoil occur where water tables are higher or microtopography is absent. Ephemerally wet soils with salt accumulations may be occupied by sparse vegetation of saltgrass (Distichlis stricta) and alkaligrass (Puccinellia nuttalliana). The banks of the largest streams support riparian willow communities dominated by Booth willow (Salix boothii) and Geyer willow (Salix geyeriana) (Cooper et al. 1995). There is a noticeable lack of willows along the lower reaches of streams such as Cabin, Meadow, Simpson, and Tex creeks. This could be due to past grazing or to a more ephemeral water table on the east side of the basin.

\section{Vegetation processes}

Big Sheep Creek Basin is a patterned mosaic of sagebrush steppe and moist meadows. The upland communities are influenced by fire, erosion and livestock grazing. Mining for gravel occurs in Big Sheep Creek Canyon. Grazing, hydrologic regime and beaver activity are influences on the wetlands.

Fire: Average fire-return intervals for big sagebrush steppe in the high valleys of southwest Montana were likely less than 25-50 years prior to European settlement (Arno and Gruell 1983). Mountain big sagebrush can be dense and grass cover high in the foothills surrounding the basin. Fire would have resulted in a mosaic of severely to lightly burned patches and reduced the cover of Artemisia tridentata which is easily killed by fire and often requires in excess of ten years to reestablish preburn stature and density. The majority of Artemisia tridentata ssp. wyomingensis stands in the basin proper are low, relatively unproductive and broken by corridors of wetland vegetation. It is likely that fire frequency on the basin floor was much lower than in the foothills. Steppe dominated by Artemisia arbuscula longiloba produces very little fuel and is probably inflammable except under rare circumstances. Occasional catastrophic crown fires would have occurred in the dense stands of Douglas fir found on steep, north-facing slopes, reducing them to open stands of shrubs such as snowberry and chokecherry. Mountain mahogany woodlands have very little fuel in the ground layer and limber pine are usually widely separated. These woodlands probably did not often burn. Fires probably had little effect on the wetland communities because willows and shrubby cinquefoil readily resprout after fire.

Erosion: Sagebrush steppe communities in the basin proper commonly support only a sparse ground layer of grasses and forbs. Evidence of sheet erosion on gentle inclines is common. Systems of shallow, ephemeral streams are apparent in some stands of low steppe in broad swales. Much of this erosion is probably a result of the fine-textured soils and the cold, arid environment with sporadic intense rain events. Water and wind erosion prevents soil from developing fertile horizons and protective ground-layer vegetation.

Grazing: Livestock grazing has occurred in southern Beaverhead County for more than 100 years. All of Big Sheep Creek Basin except some hay meadows along perennial streams are in grazing allotments. Water for livestock is widespread and regularly available throughout most of the basin in most years. Vegetation of the basin is relatively unproductive due to poor soils and the cold, arid climate. Heavy grazing that lowered the abundance of palatable grasses likely occurred in the past. Current grazing, even at moderate levels, allows only minimal recovery in this harsh environment (see Interactions below).

Livestock grazing of moist meadows can alter the habitat in several ways (Belsky et al. 1999). Heavy grazing can cause a decline of palatable bunchgrasses, such as tufted hairgrass and slender wheatgrass (Agropyron trachycaulum) with a concomitant increase of rhizomatous graminoids, such as Baltic rush, low-stature grasses like mat muhly (Muhlenbergia richardsonis), or less palatable forbs. 
Grazing in summer and fall also often results in a reduction of willows. Heavy livestock grazing and trampling causes a decline in the vigor of streambank vegetation, thereby reducing bank stability and changing stream morphology. Heavy grazing of the uplands can reduce vegetative cover, resulting in increased runoff and flash flooding that leads to stream downcutting. Finally, trampling by livestock during the spring and early summer can cause formation of hummocks in the wet, malleable soil.

Hummock-and-hollow microtopography provides drier microsites for plant colonization compared to meadows without hummocks. Meadows with hummocks often support shrubby cinquefoil and a higher plant diversity than those without. Hummocks may also alter the local hydrology, reducing the storage capacity of the meadows. The tops of hummocks may become dry and exposed to wind erosion during extended periods of drought.

Livestock can introduce invasive, exotic plants into the site. Currently, noxious weeds are not known to be present, but spotted knapweed (Centaurea maculosa) has been found at the mouth of Big Sheep Creek Canyon. It is likely that knapweed would thrive in the stony soils of the foothills surrounding Big Sheep Creek Basin.

Mineral extraction: Large quantities of gravel have been excavated from the extensive limestone talus slopes at the upper end of Big Sheep Creek Canyon. This mining causes displacement of talus above the excavation and alters the partially stabilized habitat (Vanderhorst 1995a). Operating front-end loaders and trucks in this poorly vegetated, gravelly habitat could result in establishment of weed populations.

Hydrology: Wet meadows along the many permanent creeks in Big Sheep Creek Basin depend on upwelling of groundwater and water moving out of the streams and saturating low terrace soils. The amount and timing of discharge from streams into adjacent meadow soils determines the extent, productivity and species composition of these habitats. Water levels in the creek can be influenced by upstream diversions. Livestock grazing can also impact local hydrology (see Interactions below).

Beavers: At these high elevation sites beavers feed primarily on riparian willows. Their dams create impoundments that raise the level of stream beds. Locally, they decrease the cover of willows. Over the long term beaver activities create wetlands by raising the local water table adjacent to streams they have impounded. Beavers were present on at least Cabin, Simpson and probably Nicholia creeks in the basin proper.

Process Interactions: Several of the processes interact to reinforce each other. Overgrazing reduces plant cover, causing increased erosion which lowers fertility of the poorly developed soils, further reducing plant cover and slowing recovery from past grazing. Heavy livestock grazing can cause hummocking and degrade stream banks which can affect local hydrology and lead to increased erosion of banks and hummocks. Overgrazing of uplands can increase flash flooding of streams. Downcutting of the stream channel can occur if grazing has destabilized the banks. Downcutting lowers the water table causing a drying of adjacent moist meadows. Hummocks created by trampling would be higher above the water table and may succumb to wind erosion. Beavers can raise the water table, creating more wetland habitat.

\section{Plant species of concern}

Eighteen Plant Species of Concern occur in the Big Sheep Creek Basin site (Lesica and Vanderhorst 1994, Vanderhorst 1995a). Primula alcalina and Thlaspi parviflorum are regional endemics, found only in southwest Montana and adjacent Idaho and/or Wyoming. Carex idahoa is widespread but globally rare. Aquilegia formosa, Agastache cusickii, Braya humilis, Carex norvegica ssp. stevenii, Erigeron linearis, Eriogonum caespitosum, Hutchinsia procumbens, Kobresia simpliciuscula, Lomatogonium rotatum, Primula incana, Phacelia incana, Sphaeromeria argentea, Taraxacum 


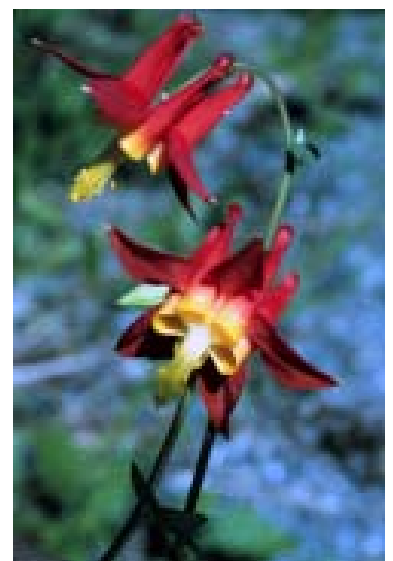

Aquilegia formosa

eriophorum, Thalictrum alpinum and Thelypodium sagittatum ssp.

sagittatum, are more widespread and common elsewhere but rare in Montana.

Agastache cusickii, Carex idahoa, Sphaeromeria argentea, Taraxacum

eriophorum and Thalictrum alpinum are listed as sensitive by BLM, and

Hutchinsia procumbens, Lomatogonium rotatum, Phacelia incana, Primula alcalina and Primula incana are on the BLM watch list. These 17 Species of Concern occur in four types of habitat: wetlands, riparian forest/shrubland, sagebrush steppe and stony slopes.

Wetlands: Ten species of rare plants are associated with the calcareous wetlands of Big Sheep Creek Basin: Braya humilis, Carex idahoa, Hutchinsia procumbens, Kobresia simpliciuscula, Lomatogonium rotatum, Primula alcalina, P. incana, Taraxacum eriophorum, Thalictrum alpinum and Thelypodium sagittatum. These habitats can be affected by livestock grazing and alteration of hydrologic regime. Livestock congregate in the vicinity of wetlands in summer for the lush, succulent vegetation and proximity to water. Carex idahoa is palatable to livestock (Hermann 1970) and could decline with heavy cattle grazing. In addition, heavy grazing promotes an increase in Kentucky bluegrass (Poa pratensis) which may compete with C. idahoa (Lesica 1998). Kobresia simpliciuscua is also a graminoid, but its palatability is not known. The other eight rare species are forbs and probably not selected by cattle. Furthermore, most of these species are low to the ground and may benefit by having the canopy of dominant graminoids reduced.

Livestock grazing can also indirectly affect wetland vegetation by altering hydrologic regimes. Trampling by cattle may benefit many of the rare species by creating mesic microhabitats on the tops and sides of the hummocks. Hummock habitats are moist without being wet and are more open than wetter microhabitats dominated by sedges and rushes. Some of the rare species, such as Carex idahoa, Kobresia simpliciuscula, Primula alcalina, P. incana, Taraxacum eriophorum and Thalictrum alpinum, often occur on hummocks and might decline in their absence (Muir and Moseley 1994). Livestock grazing in the uplands can reduce vegetal cover, thereby increasing runoff, flash flooding and channel downcutting. The lowered water table that accompanies downcutting causes a diminution of wetland habitat. Loss of wetlands would likely result in population declines for at least some of the ten rare species, such as Carex idahoa, Kobresia simpliciuscula, Lomatogonium rotatum, Primula alcalina, $P$. incana and Thalictrum alpinum. Other species, such as Braya humilis, Hutchinsia procumbens and Thelypodium sagittatum ssp. sagittatum, are found in salty, ephemerally moist soils on the margins of wetlands and could increase with the drying of wet meadows.

Many of the permanent streams in Big Sheep Creek Basin have diversions for irrigation. Withdrawal of water during summer months lowers stream levels and the associated riparian water table. Chronic dewatering will result in the loss of wetland habitat and a decline in some rare plants (listed above).

Beavers were present in Big Sheep Creek Basin in recent years and probably were common before Europeans entered the area. The presence of beavers often results in an increase in wetland habitat through a raising of the water table and trapping of silt behind impoundments. The long-term increase of wetland habitat would likely benefit many of the rare species (listed above).

Riparian: Aquilegia formosa and Carex norvegica ssp. stevenii occur in moist, open forest or beneath willows along streams and around lakes. These habitats can be affected by livestock grazing and beavers. They are too far upstream to be affected by stream diversions. Cattle are attracted to the shade and succulent vegetation of riparian areas in summer. The mesic understory vegetation of these habitats can be degraded by overgrazing. In the short term, beavers remove willows and flood riparian 
zones, resulting in a loss of shrubs. However, over the long term, beavers increase riparian habitat that supports these two plants.

Sagebrush: Sagebrush communities provide habitat for five rare plants: Erigeron linearis, Eriogonum caespitosum, Sphaeromeria argentea, Taraxacum eriophorum and Thlaspi parviflorum. Fire, erosion and grazing are the three important forces affecting this widespread habitat. Disturbance from fire reduces competition from big sagebrush and could be important in maintaining Taraxacum eriophorum and Thlaspi parviflorum populations. Erigeron linearis, Eriogonum caespitosum and Sphaeromeria argentea occur in low sagebrush or very sparse big sagebrush communities. Fire or lack of it is unlikely to affect these three species because fire was rare in these habitats, and competition for light will rarely be a limiting factor. Livestock grazing generally favors broad-leaved forbs at the expense of graminoids. All five species are low to the ground so they are likely to benefit from removal of dominant grass canopy. Furthermore, Taraxacum and Thlaspi flower and fruit early, so they are unlikely to be adversely affected by all but early-season grazing. Erigeron linearis, Eriogonum caespitosum and Sphaeromeria argentea all tend to occur in sparse vegetation of low sagebrush steppe. Erosion retards soil development and poor soil will not support dense vegetation. Thus, the sheet erosion observed in low sagebrush habitats could be beneficial to these three species.

Slope: Agastache cusickii, Hutchinsia procumbens, Phacelia incana and Sphaeromeria argentea occur on steep slopes with minimal soil development and sparse vegetation. Erosion and mining activity will have the greatest impacts on this habitat. All species are low in stature, and presumably all are adapted to shallow soil and low levels of competition. Naturally low levels of erosion are required to prevent larger plants from invading these habitats. However, these habitats are prone to slope failure and massive erosion when impacted by road-building or other activity causing a large disturbance. Talus slopes of Madison limestone that provide habitat for Agastache, Hutchinsia and Phacelia have been quarried for road gravel. Steep slope habitat is little influenced by fire or grazing.

\section{Conservation significance}

The region encompassed by Beaverhead, Madison and Silver Bow counties has the greatest number of globally rare plants in Montana. Big Sheep Creek Basin supports metapopulations of three globally rare species (G1-G3): Carex idahoa, Primula alcalina and Thlaspi parviflorum. The former two species are associated with wetlands. The Carex idahoa metapopulation in Big Sheep Creek Basin is one of the largest if not the largest in Montana. The Primula alcalina population is the only one known in Montana and one of fewer than ten globally (Elzinga 1997). Another Montana Species of Concern, Kobresia simpliciuscula, is common in boreal regions but rare in the Continental U.S. Six other species that are rare in Montana but widespread and more common elsewhere also occur in these wetlands. All should be considered highly vulnerable because the calcareous wetlands are sensitive habitats prone to degradation from water diversion and livestock grazing. Eight plant Species of Concern are found in upland or riparian habitats of Big Sheep Creek Basin. Only one, Thlaspi parviflorum, is globally rare. Two others that are rare in Montana but more common elsewhere, Aquilegia formosa and Carex norvegica ssp. stevenii, may be quite vulnerable because they occur in riparian areas prone to livestock degradation.

All but one (Carex norvegica ssp. stevenii) of the 18 plant Species of Concern found in Big Sheep Creek Basin occur on lands administered by BLM. Five species, Agastache cusickii, Carex idahoa, Sphaeromeria argentea, Taraxacum eriophorum and Thalictrum alpinum, are designated Sensitive by BLM, and five others - Hutchinsia procumbens, Lomatogonium rotatum, Phacelia incana, Primula alcalina and Primula incana - are on the BLM watch list. This area also supports low sagebrush communities of Artemisia arbuscula/Agropyron spicatum, Artemisia longiloba/Agropyron smithii and 
Artemisia longiloba/Festuca idahoensis, which are rare in Montana, and found only in Beaverhead County. The latter two community types are globally rare.

\section{Management}

At least half of Big Sheep Creek Basin, including the majority of the wetlands, is privately owned. Nearly all of the public land in the basin proper is managed by BLM. Management of the foothills area is shared between BLM and Beaverhead-Deerlodge National Forest. Wetlands on public lands are key because most of that habitat is in private ownership and not managed for biological conservation. Restricting livestock grazing to the later part of the summer in as many years as possible would help minimize damage to streambanks. Careful management of grazing should help restore grass cover in the uplands and protect the hydrology of wetlands and riparian areas. If willows (Salix planifolia, S. boothii, S. geyeriana) can be re-established along Cabin and perhaps Simpson creeks, beavers may colonize and help restore wetland habitat. Stream reaches with downcutting could be dammed to raise the local water table. Low sagebrush communities, Artemisia arbuscula/Agropyron spicatum, Artemisia longiloba/ Agropyron smithii and Artemisia longiloba/Festuca idahoensis are rare in Montana, found only in Beaverhead County. The latter two community types are globally rare.

\section{Further research}

The occurrence of Primula alcalina, Carex idahoa and other rare plants should be mapped to the extent possible on private land in the Cabin Creek drainage (including Simpson, Tex and Alkali creeks). Research to understand the effect of hummock microtopography on hydrology and rare plant populations, especially P. alcalina, would likely benefit conservation efforts. Stream bed morphology should be mapped and monitored on public land reaches of permanent creeks. The extent of sheet erosion in uplands should be monitored. Permanent photo points placed in some subpopulations would aid in tracking changes in habitat. Roadsides should be monitored for weeds. 


\section{BROWNES GULCH}

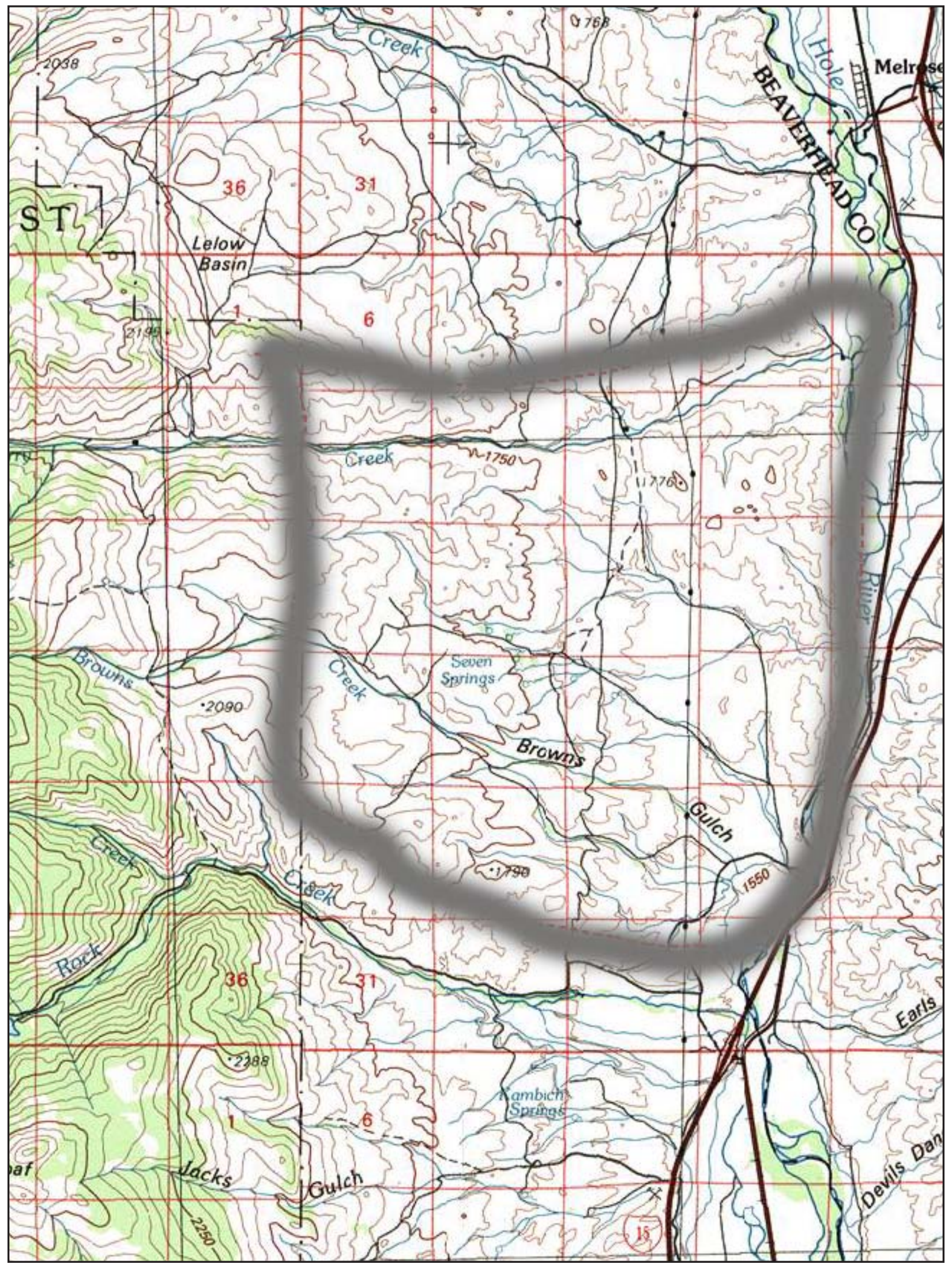




\section{Description}

\section{BROWNES GULCH}

Brownes Gulch lies in the eastern foothills of the East Pioneer Mountains, in northern Beaverhead County. It is bounded on the east by the Big Hole River and on the west by the boundary of BeaverheadDeerlodge National Forest. The area is primarily administered by BLM and includes the lower basins of Brownes Gulch, Cherry Creek and the smaller intermittent drainages in between. Elevation range from 5,100 ft along the Big Hole River to about 6,500 ft at the forest boundary. The area is subject to livestock grazing, and big game hunters use it during hunting season.

\section{Geology and soils}

Volcanic rocks form the bluffs along the Big Hole River. Farther west are Mesozoic and Paleozoic sedimentary rock frequently intruded by granite from the adjacent Pioneer batholith just to the west. Soils are variable. Those in the eastern portion of the site are relatively deep except on steep slopes and ridge tops. Soils are very stony in the western portion of the site where topography is steeper and more broken.

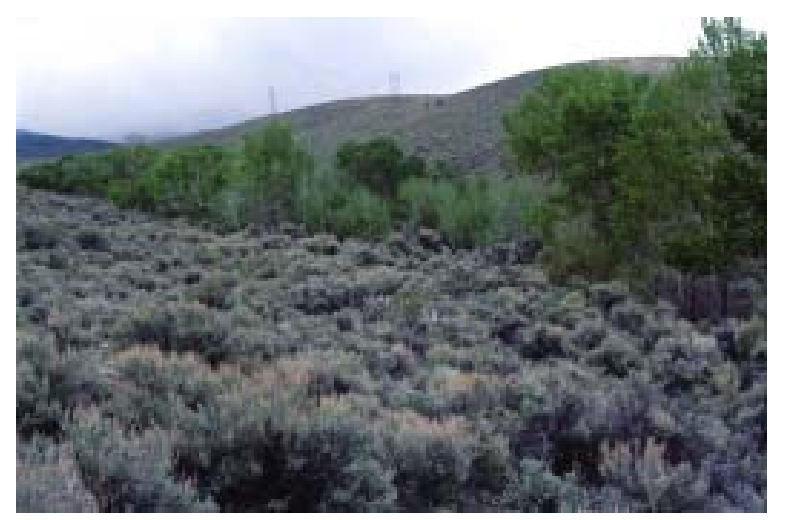

Brownes Gulch, Beaverhead Co.

\section{Vegetation}

Dominant upland vegetation of Brownes Gulch is sagebrush steppe. The Artemisia tridentata vaseyana/Festuca idahoensis community type is dominant throughout much of the site, although the Artemisia tridentata wyomingensis/Agropyron spicatum community type can be found in the eastern portion. Artemisia tridentata tridentata/Agropyron smithii shrub steppe occurs on terraces along intermittent streams.

\section{Extensive wet aspen (Populus tremuloides)}

forests are associated with a series of springs at the headwaters of an intermittent stream between Brownes Gulch and Cherry Creek. Stands are dominated by small- and middle-size aspen stems. The understory of these wet forests is dominated by Salix scouleriana and Cornus stolonifera with Equisetum arvense and other wet-site indicators in the ground layer. These aspen stands are isolated in the midst of steppe vegetation and contribute greatly to the biological diversity of the site. They provide important habitat for moose, elk, deer and songbirds.

A narrow riparian stringer occurs along Brownes Gulch in the western portion of the area. Populus trichocarpa and P. tremuloides form the overstory. Symphoricarpos occidentalis and Poa pratensis are common in the understory. Trees of many different ages are found along the stream, suggesting that regular regeneration is occurring. Adjacent higher terraces may support basin big sagebrush (Artemisia tridentata tridentata) and/or greasewood (Sarcobatus vermiculatus) shrubland.

\section{Vegetation processes}

Upland vegetation dominates this area. Steppe communities are influenced by fire and ungulate grazing. Wetland and riparian communities associated with Seven Springs and Brownes Gulch can be influenced by ungulate grazing, beaver activity and altered hydrologic regimes.

Fire: Average fire-return intervals in steppe vegetation in valleys of southwest Montana were likely less than 25-50 years prior to European settlement (Arno and Gruell 1983). These fires caused a mosaic of severely to lightly burned patches and reduced the cover of Artemisia tridentata which is easily killed by fire and often requires in excess of ten years to reestablish preburn stature and density. Aspen groves were probably too wet to carry most fires and burned only rarely. However, fire is thought to be an 
important process for rejuvenating decadent aspen stands. Stringers of cottonwood and aspen were probably narrow and dry enough to carry a fire. Aspen resprouts more readily than black cottonwood, so fire would likely have resulted in increased aspen at the expense of cottonwood.

Grazing: Livestock grazing has occurred in Beaverhead County for more than 100 years. The entire Brownes Gulch site is in grazing allotments; however, portions of the Seven Springs area may be fenced out from livestock grazing. Grazing is expected to lower the abundance of palatable grasses in steppe vegetation. Grass cover seemed lower than expected in the eastern portion of the site where topography is more gentle. This may be due to past overgrazing and/or the aridity of the area due to the rain shadow of the Pioneer Range. Water is found only on upper Brownes Gulch, Cherry Creek and around the Seven Springs area. These areas have been impacted by livestock grazing. Some of the aspen stands show signs of trampling and compaction in wet areas. Well-used cattle trails occur along Brownes Gulch, and much of the ground layer vegetation is the introduced Poa pratensis. The Seven Springs area is used by elk and moose. It is possible that large numbers of elk could use the area in some years, having an impact similar to livestock

Livestock can introduce invasive, exotic plants into the site. Spotted knapweed (Centaurea maculosa) was observed along an ephemeral stream in the center of the site near the power line corridor.

Beavers: Beavers were undoubtedly present on Brownes Gulch and Cherry Creek at some times in the past. Beavers destroy the dominant cottonwood and aspen along permanent streams while creating ponds and wetlands. Beavers were not observed along Brownes Gulch.

Hydrology: Hydrologic regime affects both wetland and riparian vegetation. It appears that hydrology of the site is not affected by human disturbance. Flooding associated with periodic high winter snowpack has promoted recruitment of cottonwood along Brownes Gulch. Deep groundwater springs maintain the wet environment that supports aspen forest in the Seven Springs area.

\section{Plant Species of Concern}

Kochia americana is the only plant species of concern known from Brownes Gulch (Heidel and Vanderhorst 1996). It is commonly associated with greasewood shrubland at the border between wetland or riparian areas and upland vegetation. Kochia americana occurs throughout much of the western U.S. but in Montana is known from only a few sites in Beaverhead County. It is not listed as Sensitive by BLM. It has been found in four sections along Brownes Gulch and the Big Hole River. This plant is probably not very palatable to livestock, and the

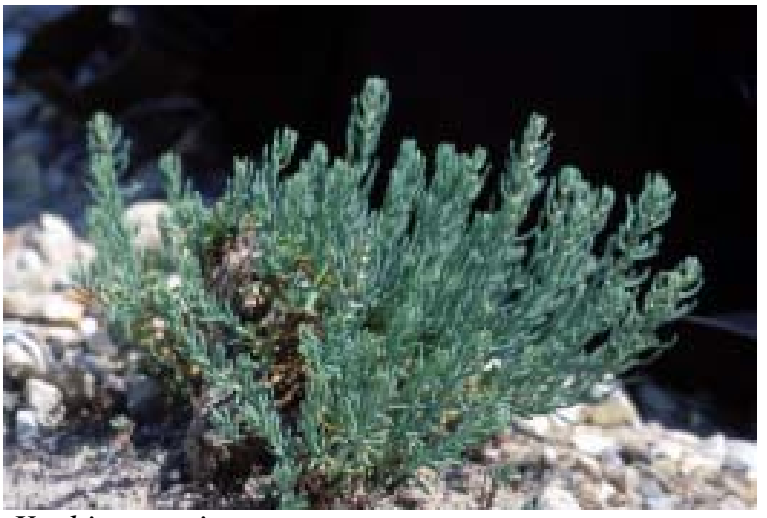

Kochia americana rhizomatous growth form probably makes it resistant to trampling. Alteration of stream flows could affect the adjacent water table and adversely affect this plant's habitat.

\section{Conservation significance}

The wetland and riparian plant communities are the most significant biological features of this site, which encompasses extensive aspen woodlands and wetland vegetation associated with springs in the western portion. There is a healthy cottonwood-dominated riparian area in Brownes Gulch on the southern part of the site. Several stands of basin big sagebrush occur along intermittent streams in the eastern half of the site. These communities provide important habitat for moose, elk, deer and songbirds. Only one Plant 
Species of Concern is known to occur in Brownes Gulch: Kochia americana. It is known from fewer than five locations in Montana but is more common elsewhere.

\section{Management}

The primary biological values of Brownes Gulch are associated with the wetland and riparian habitats. These plant communities can be degraded by ungulate grazing. It is likely that a rest-rotation or deferred livestock grazing regime would help protect the quality of these communities.

\section{Further research}

More thorough survey work of the Seven Springs wetlands, Cherry Creek and Brownes Gulch riparian areas and basin big sagebrush steppe is needed to assess their condition and full significance. 


\section{CENTENNIAL SANDHILLS}

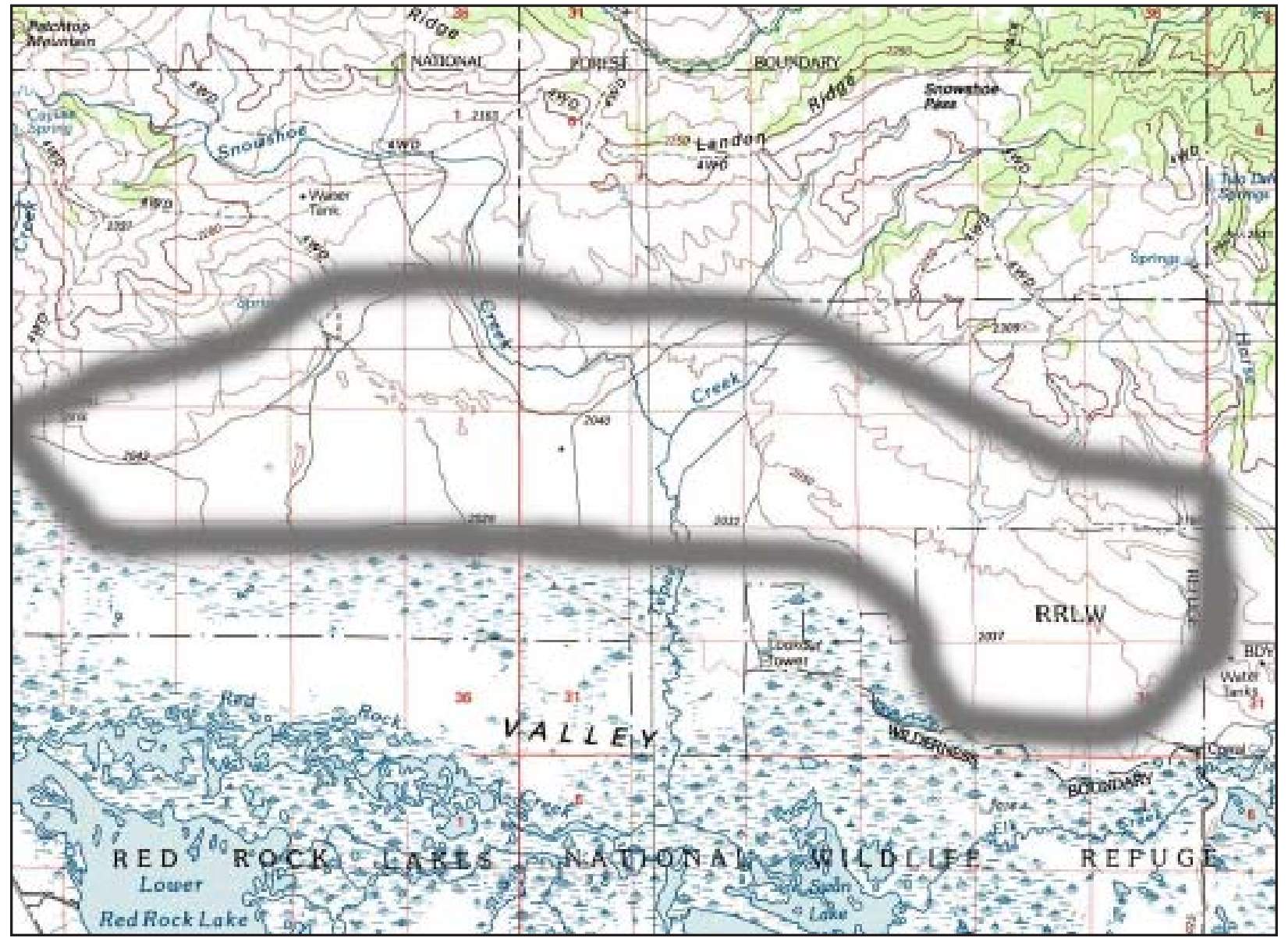




\section{CENTENNIAL SANDHILLS}

\section{Description}

The Centennial Sandhills lie in the northeast corner of the Centennial Valley, a broad trough at the head of the Red Rock River. The valley floor lies at 6,500-6,600 ft with the Centennial Mountains rising abruptly to about $10,000 \mathrm{ft}$ on the south and grading more gently into the Gravelly and Snowcrest ranges on the north. Upper and Lower Red Rock Lakes are large, shallow, natural bodies of water at the east end of the valley. The Centennial Sandhills are found in a band 1-2 miles wide and about 9 miles long on the north side of the lakes. The Sandhills site encompasses all of the azonal, sandy soils and the unusual vegetation they support on the

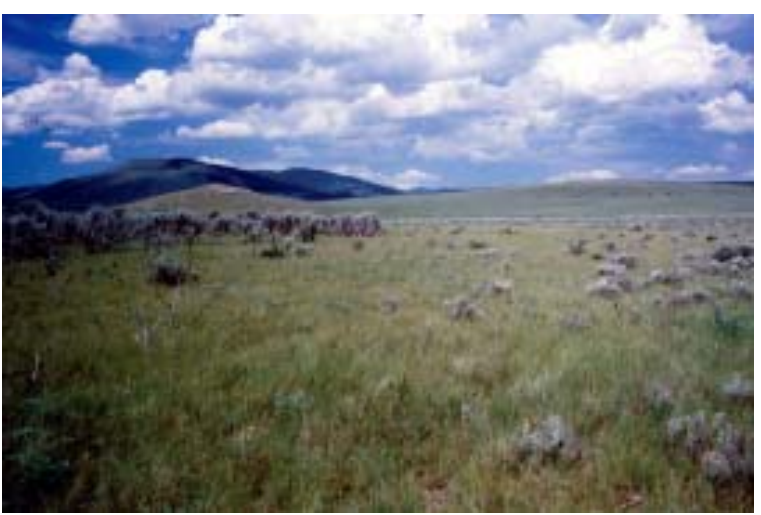

Centennial Sandhills, Beaverhead Co. north side of Upper Red Rock Lake. The area is subject to livestock grazing on both private lands and BLM lands. Refuge lands administered by the U.S. Fish and Wildlife Service are not grazed, and are part of the Red Rock Lakes Wilderness Area. Big game hunters use the area during hunting season.

\section{Geology and soils}

The sandhills are small, generally stabilized, dunes that formed from wind-blown sands deposited in the basins of Red Rock Lakes, probably during the late Pleistocene (ca. 10,000 BP). At this time the lakes retreated, exposing sandy shorelines. Shores farthest from the center of the lakes would have been exposed first. Thus, dunes farthest from the lake may be the oldest. Dune activity in this region is controlled by the tension between wind and vegetation. Periods of active movement have probably alternated with periods of relative stabilization. Periods of drought or disturbances such as fire or grazing may initiate new episodes of migration. During periods of active migration the dunes move from southwest to northeast, depositing a layer of sand on the gently sloping, broad valley floor. As sand is lost the dunes become smaller. Eventually enough sand is lost that vegetation stabilizes the dune, and movement ceases.

The interaction between vegetation and wind-blown sand controls dune morphology. Examination of aerial photos of the area indicates that primary dunes are longitudinal, with low ridges running southwest-northeast, parallel to the direction of prevailing winds. Superimposed on these older ridges are blowout or parabolic dunes that are ellipsoidal to elongate U-shaped and 30-60 ft high. Leeward slopes are steep (са. 30-60\% slope), while windward slopes are more gently sloping and often bowl-, crater- or trough-shaped. Prevailing winds of sufficient strength transport sand from the windward slope and deposit it on the crest or leeward slope, often in an "apron" around the blowout. In this way dunes move to the northeast. Shapes of individual dunes are modified from parabolic by strong cross winds and differential growth of stabilizing vegetation. Sand dunes in the Centennial Valley are in various states of activity. In general, the highest and most active dunes are north of Lower Red Rock Lake. Those in the eastern portion of the area are lower and well stabilized (Lesica and Cooper 1996).

Soils vary from pure sand in blowouts and recent deposition areas to loamy sand in the more stabilized areas, especially those with relatively little topographic relief. Organic matter varies from a mean of $2 \%$ in stabilized positions to $0.6 \%$ in erosional and depositional positions (Lesica and Cooper 1996).

\section{Vegetation}

Vegetation of the Centennial Sandhills is a mosaic of early-seral communities on erosional and deposition sites and late-seral associations in more stabilized interdune areas. Early-seral upper slope and lower slope sites support a sparse shrub cover of Chrysothamnus nauseosus, Chrysothamnus viscidiflorus, 
and Tetradymia canescens and a sparse ground layer of mainly Agropyron dasystachyum, Stipa comata and Psoralea tenuiflora. This is the Chrysothamnus viscidiflorus/Stipa comata community type of Cooper et al (1995). As succession proceeds this early-seral disturbance type develops into three late-seral vegetation types dominated by Artemisia tridentata ssp. tridentata and/or A. tripartita, Festuca idahoensis, S. comata, and Lupinus sericeus. These are the Artemisia tridentata tridentata/ Festuca idahoensis and Artemisia tridentata tridentata/Stipa comata community types and the Stipa comata phase of the Artemisia tripartita/Festuca idahoensis community type (Cooper et al. 1995; see Lesica and Schassberger 1988, Lesica and Cooper 1996 for more detailed descriptions of the vegetation).

\section{Vegetation processes}

Centennial Valley Sandhills vegetation is been influenced by successional forces, fire, drought, pocket gophers and livestock grazing.

Succession: Succession proceeds from sparsely vegetated sandy soils toward more densely vegetated loamy sands with increased organic matter (Lesica and Cooper 1996, 1999). The sparse shrub canopy dominated by Chrysothamnus viscidiflorus, C. nauseosus and Tetradymia canescens and sparse cover of Stipa comata and Agropyron dasystachyum develops into sagebrush steppe. Succession is retarded and climax communities revert to earlier seral stages when vegetal cover is removed and wind erosion is reinitiated. Three processes cause an increase in bare ground in sandhills systems: fire, ungulate grazing, and pocket gopher digging and grazing. In addition to these three factors, extended periods of drought cause a reduction in vegetation and an increase in open ground and erosion potential.

Fire: Average fire-return intervals at the ecotone between forest and sagebrush grasslands of the high valleys in southwest Montana were 25-50 years prior to European settlement, and fire frequency was likely higher in the grasslands proper (Arno and Gruell 1983). These fires caused a mosaic of severely to lightly burned patches and reduced the cover of Artemisia tridentata which is easily killed by fire and often requires in excess of ten years to reestablish preburn stature and density. Early-seral dominant shrubs, Chrysothamnus spp. and Tetradymia canescens, resprout immediately following fire and may increase in abundance.

Artemisia tripartita is the dominant late seral shrub in portions at the west end of the study area. This species is not killed by fire and is able to resprout from the root crown. Succession should proceed more quickly following fire in areas dominated by A. tripartita compared to those dominated by $A$. tridentata ssp. tridentata. We expect less early seral vegetation in these areas when fire frequencies are equal.

The rhizomatous, early seral dominants Agropyron dasystachyum and Psoralea tenuiflora suffer little damage from fire, while dominant late seral grasses, Festuca idahoensis and Stipa comata, are often harmed by fire and may not return to preburn levels for 12-30+ years. Early seral vegetation is relatively sparse and would not be likely to carry a hot fire. Fire may cause an increase in the proportion of rhizomatous grasses compared to the bunchgrasses, possibly resulting in destabilization of dune vegetation because bunch grasses are better at deterring wind erosion. Fire suppression and the concomitant increase in vegetal cover is thought to be the main cause of dune stabilization in the Nebraska Sandhills in the recent past.

Drought: Soils supporting seral communities have lower water-holding capacity because they have less organic matter and coarser texture. Slope and hilltop positions will suffer the highest evaporation stress. Consequently, the adverse effects of prolonged drought will be most pronounced in early seral sandhills communities, lowering vegetal cover and increasing instability. More xeric conditions will occur on southerly slopes due to increased evapotranspiration resulting from higher solar radiation loads and exposure to prevailing winds. 
Pocket gophers: Pocket gopher (Thomomys talpoides) diggings in the Centennial Sandhills were observed in early successional vegetation in both upper slope depositional and lower slope erosion sites and were more frequent on steeper slopes. Evidence of gophers was not observed in late-seral plots. Pocket gophers reduce vegetal cover and increase bare soil by grazing vegetation and mounding soil. Rhizomatous grasses and forbs generally increase with pocket gopher grazing and digging.

Pocket gophers retard or reverse succession by increasing open sand, often eliminating vegetation in small patches, and causing a relative increase in the rhizomatous species A. dasystachyum and Psoralea tenuiflora at the expense of bunchgrasses such as $S$. comata and F. idahoensis. Gophers may prefer early and mid-seral vegetation because their principal foods, A. dasystachyum, Psoralea tenuiflora, and Opuntia fragilis are most common. Pocket gophers are likely an important force in preventing early to mid-seral habitats from advancing to late successional vegetation by reinitiating blowouts.

Livestock grazing: Bison (Bison bison) were present in the Centennial Valley prior to the advent of Europeans in southwest Montana; however, their impact on the sandhills is not known. (Haines 1955). Since settlement the study area has been grazed by sheep and cattle. Livestock grazing has been the only significant human-caused disturbance affecting the Centennial Sandhills. Pasturing of domestic sheep in the Centennial Valley began in the late 1800's and continued until the 1940's. Cattle grazing replaced sheep and continues until the present. Permanent ranches were present in the valley during the first half of this century, and livestock grazing was likely higher at that time. Land managed by the BLM has been consistently grazed since 1939 .

In general, cattle prefer grasses while sheep prefer forbs, although there is a great deal of variability among different sites and different populations of animals. Both Agropyron dasystachyum and Stipa comata are given fair or fair-to-good palatability ratings. Festuca idahoensis is rated as good to very good for both grazing species. Palatability of Psoralea tenuiflora is very poor and poor for cattle and sheep respectively. Livestock are expected to retard succession, mainly by reducing vegetal cover from grazing and creating open sand from trampling on steep slopes. There is little evidence that moderate stocking levels result in an increase of early successional habitat.

Livestock can introduce invasive, exotic plants into the site. Currently, noxious weeds are not known to be present, but spotted knapweed (Centaurea maculosa) has been found in the Centennial Valley. It is not known how knapweed would respond to very sandy soils.

Process interactions: In the absence of disturbance, early-seral vegetation, with low shrub, grass and litter cover, will proceed to late-seral vegetation with moderate shrub cover and high grass and litter cover. Mid-seral vegetation is intermediate in composition. Fire causes late seral vegetation to revert to mid-seral. Mid- and early seral vegetation have too little litter or shrub cover to carry a fire. Prolonged drought reduces fuel and makes fire less likely and less severe. Moderate grazing probably has little effect except for localized trampling that may help maintain mid-seral vegetation. Fire followed by grazing can initiate blowouts and convert late seral to early seral vegetation. Gopher digging and grazing is rare in late seral vegetation and converts mid-seral to early seral vegetation, promoting blowouts on a local scale. Prolonged drought retards succession.

The height and frequency of sandhills varies across the study area. More level areas may be less likely to have active blowouts, and would be expected to have higher proportions of late seral vegetation. Existing topography as well as disturbance regimes control the proportion of seral vegetation on the Centennial Sandhills landscape.

\section{Plant species of concern}

Three Montana Plant species of Concern occur in the Centennial Sandhills. Astragalus ceramicus var. apus occurs only in the Centennial Sandhills and the sandhills of southeastern Idaho. Cryptantha

$$
\text { Appendix C - } 15
$$




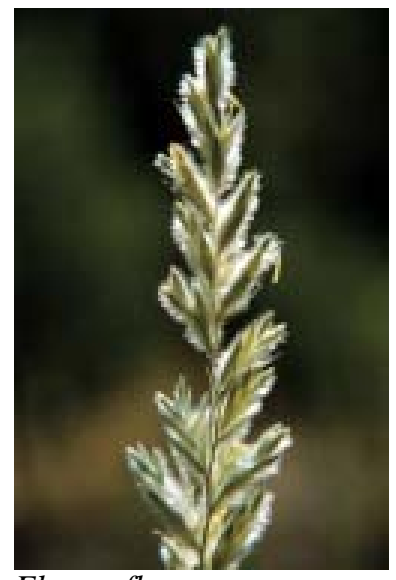

Elymus flavescens fendleri is sparsely distributed throughout much of western North America, but is known from only two widely separated areas of Montana. Elymus flavescens occurs in sandy soil in the northwest U.S., but in Montana occurs only in the Centennial Sandhills. All three species are found in the sandy soil of early-seral communities and are absent or rare in late-seral sagebrush steppe (Schassberger 1988). Succession will tend to diminish the amount of earlyseral habitat. Disturbance regimes that create or maintain early-seral vegetation (fire, drought, gophers, grazing) will be necessary to preserve these rare species in the sandhills landscape.

\section{Conservation significance}

The Centennial Sandhills are the highest-elevation sandhills in Montana and the entire Northern Rocky Mountains. They support the only Montana populations of the globally rare Astragalus ceramicus var. apus, which occurs only in the

fendleri, two other species found here, are more widespread globally but are highly restricted in Montana. The Centennial Sandhills also include the only Montana location for two plant communities, the Chrysothamnus viscidiflorus/Stipa comata and Artemisia tridentata tridentata/Stipa comata community types. The area also provides habitat for two animal Species of Concern: Preble's shrew and the Great Basin pocket mouse (Hendricks and Roedel 2002). Without special management, many of the biological values of this unique site could be lost.

\section{Management}

Maintaining the biological diversity of the Centennial Sandhills depends on maintaining a mosaic of different seral vegetation types. The three rare plants, Astragalus ceramicus var. apus, Cryptantha fendleri and Elymus flavescens, all require the open sand of early seral vegetation to persist. Late seral vegetation of the Sandhills, the Artemisia tridentata ssp. tridentata/ Stipa comata association, is found nowhere else in Montana and may also harbor rare or unusual organisms.

Disturbance regimes in the Centennial Sandhills have likely been altered significantly. Human fire suppression has been effective at reducing the frequency of wild fires in Montana over the past 50-60 years. Although there have been fires in the Centennial Sandhills during this time, it is likely that firereturn intervals have become longer. The intensity of grazing by bison in pre-European times is not known. We suspect that livestock densities (mainly sheep) were high, and grazing was season-long in the late 1800's and the early 1900's. Livestock grazing on public lands in the Sandhills has probably been more moderate in the past 50 years. Lower fire frequencies and moderate stocking rates have probably resulted in a decrease in early seral vegetation compared to presettlement conditions.

Much of the eastern portion of the Sandhills, including Red Rock Lakes Wilderness, has lower topographic relief and is almost completely dominated by mid- to late seral vegetation. Pocket gophers are uncommon, probably due in part to the paucity of slope habitat. Of the three rare plant species, only Cryptantha fendleri was observed in this area. Controlled fire followed by intense livestock grazing for 1-2 years should significantly reduce vegetal cover, allow reinitiation of active blowouts, and ultimately increase the proportion of early seral vegetation. Returning to presettlement fire return intervals of 20-30 years and moderate ungulate grazing, at least in years following burns, will probably maintain a significant proportion of early seral vegetation.

There is more topographic relief in the western third of the sandhills. Active blowouts, early seral vegetation, and pocket gophers are common. All three rare plants are present, although Elymus flavescens is uncommon. Gopher activity is an important force in initiating blowouts and maintaining early seral vegetation in this area. Managing for presettlement fire return intervals of 20-30 years should increase the proportion of mid-seral vegetation, thereby increasing pocket gopher habitat. Increased 
gopher activity will increase the proportion of early seral vegetation. High levels of ungulate grazing will also help maintain early seral vegetation on slopes where trampling is significant. Fire followed by high levels of ungulate grazing could destabilize a significant proportion of the late and mid-seral vegetation on the hills, creating more early seral habitat.

\section{Further research}

The above recommendations are based on observational data rather than experiments and should be viewed as hypotheses. These hypotheses should be tested using demonstration areas where various management strategies are applied on a small scale with or (if necessary) without replication. Results of these experiments can be used to revise the models and management prescriptions. This strategy of adaptive management will allow land stewards to better understand the relationships among the frequency, scale and intensity of major disturbance processes, eventually leading to a sustainable mosaic of early and late seral vegetation capable of supporting the full spectrum of native species. Management of the Centennial Sandhills is divided among the Bureau of Land Management, the U.S. Fish and Wildlife Service and private landowners. Management actions in the sandhills should be coordinated among these stakeholders. 


\section{EAST CENTENNIAL MOUNTAINS}

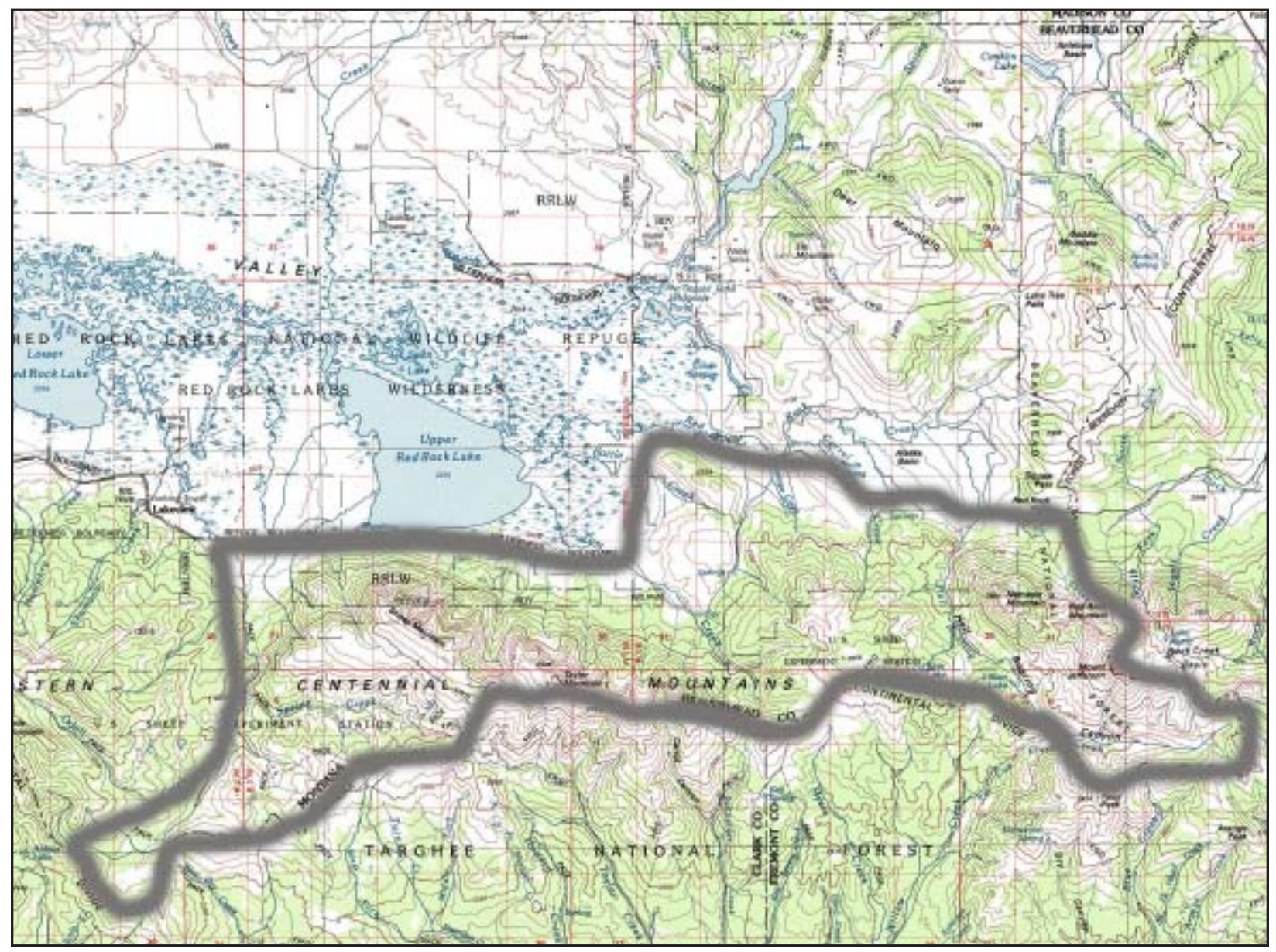




\section{Description}

\section{EAST CENTENNIAL MOUNTAINS}

This area lies on the east portion of the Centennial Mountains, an east-west trending range that forms the border between Montana and Idaho in southern Beaverhead County. The area is bounded on the south and east by the state line, approximately the summit of the Centennial Range. The west boundary is Odell Creek, and north boundary is the floor of the Centennial Valley, as demarcated by the main east-west county road. Elevations range from 6,700 ft along Odell Creek on the valley floor to 10,200 ft at the summit of Mount Jefferson. Numerous streams dissect the north face of the Centennial Range, and there are there are two small, montane lakes south of Nemesis Mountain in the east portion of the site.

There is a large inactive mine near the summit of Taylor Mountain in the western portion of the area, with roads approaching from the Idaho side of the range. Otherwise the area is virtually roadless and is used primarily for recreation, such as hunting and camping. Parts of the area lie within in a national wildlife refuge, and BLM wilderness study area.

\section{Geology and soils}

The East Centennial Mountains have a core of Precambrian metamorphic rock overlain by Paleozoic limestone and Mesozoic limestone, shale and sandstone. Limestone is the dominant parent material at the site, forming large cliff faces and talus slopes on the north side of the range. Evidence of landslides and avalanches is common. Soils are generally stony and silty in texture. Skeletal, limestone-derived soils are common. Soils of the Centennial Valley floor are derived from siltstones, sandstones, limestones and shales of the Beaverhead Formation. They are high in calcium carbonate.

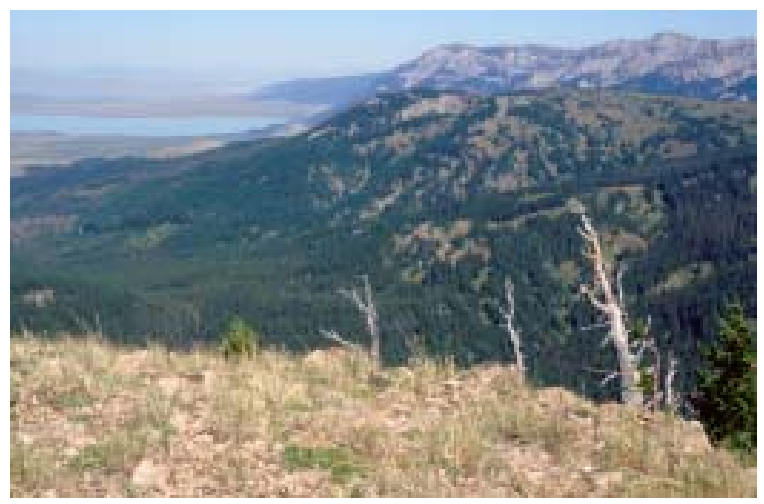

Nemesis Mountain, Beaverhead Co.

\section{Vegetation}

The East Centennial Mountains support vegetation typical of the mountains of southwest Montana and adjacent Idaho. Sagebrush steppe dominated by Artemisia tridentata vaseyana, Idaho fescue (Festuca idahoensis) and Stipa occidentalis, is found along the edge of the valley floor and the foothills as well as lower slopes along Odell and Hell Roaring creeks. Aspen (Populus tremuloides) woodlands are uncommon in concave foothills sites. Coniferous forests dominated by Douglas fir (Pseudotsuga menziesii) predominate on the lower montane slopes. Forests of

Engelmann spruce (Picea engelmannii), lodgepole pine (Pinus contorta) and subalpine fir (Abies lasiocarpa) can be found at higher elevations in less exposed sites such as moist subalpine cirque basins. Riparian corridors along Odell and Hell Roaring creeks support willows (Salix spp.), aspen and probably alder (Alnus viridis). Steppe vegetation occurs on the crest and gentle slopes above 8,500 ft with warm exposures. Exposed sites support alpine grasslands dominated by Idaho fescue, bluebunch wheatgrass (Agropyron spicatum), Lupinus argenteus and low forbs. Slopes with more snow cover are dominated by sagebrush steppe similar to that found at lower elevations. Limestone summits over 9,000 ft support sparse fellfield vegetation dominated by Carex rupestris and cushion-plant forbs (Cooper et al. 1995, Cooper et al. 1997).

\section{Vegetation processes}

Upland vegetation dominates this area. These communities are influenced by fire, livestock grazing and mining activity. Erosion plays an important role in structuring upland communities on steep slopes with poorly developed soils. Hydrologic events (i.e., flooding) and beavers played an important role in determining vegetation along streams such as Odell Creek. 
Fire: Average fire-return intervals in steppe vegetation in the high valleys of southwest Montana were likely less than 25-50 years prior to European settlement (Arno and Gruell 1983). These fires caused a mosaic of severely to lightly burned patches and reduced the cover of Artemisia tridentata, which is easily killed by fire and often requires in excess of ten years to reestablish preburn stature and density. Fires were also common in the coniferous forests, occurring every 50 years on average (Pohl, undated). Low-elevation Douglas-fir forests probably experienced frequent non-lethal ground fires, with occasional catastrophic crown fires, reducing them to open stands with shrubs such as snowberry (Symphoricarpos albus), juniper (Juniperus communis) and chokecherry (Prunus virginiana) dominating. Spruce-fir forests probably experienced uncommon stand-replacing fires. Aspen resprouts and is thought to be rejuvenated by fire. Fires probably had little effect on grasslands, fellfield and riparian willow communities.

Grazing: Livestock grazing has occurred in southern Beaverhead County for more than 100 years; however, the majority of the East Centennial Mountains is coniferous forest or cliffs and rocky slopes not exposed to livestock. Cattle graze the steppe on the foothills and valley floor, while domestic sheep are grazed on the crest of the mountains from Blair Lake west to Sheep Mountain. Cattle prefer graminoids, and these species decline, while most broad-leaved forbs increase. Sheep prefer some forbs but avoid others, so some broad-leaved species like lupine increase. Livestock can adversely affect riparian areas by browsing willows and young aspens as well as reducing the herbaceous cover. Livestock can introduce invasive, exotic plants into the site. Spotted knapweed (Centaurea maculosa) has been found along the main county road and just west of the mouth of Hell Roaring Canyon.

Mineral extraction: Inactive open pit mines occur on the south side of Taylor Mountain just north of the Idaho border. Old roads, tailings heaps, and flooded pits occur at the site. This mining activity is probably responsible for many of the two-track roads found in the area. Roads, especially on steep slopes, can cause soil erosion. The site may be too high $(9,500 \mathrm{ft})$ to provide habitat for invasive exotics.

Erosion: Evidence of erosion is common wherever there are steep slopes or stream channels, preventing soil development and the presence of dense vegetation. Wind erosion, prevalent on exposed upper slopes and ridge crests, maintains the skeletal nature of the soil and promotes the existence of distinctive plant communities, especially at high elevations.

Hydrology: The amount and timing of discharge from streams into adjacent riparian soils determines the extent, productivity and species composition of these habitats. Livestock grazing can also impact local hydrology (see Interactions below).

Beavers: At high elevation sites beavers feed primarily on riparian willows. Their dams create impoundments that raise the level of stream beds. Locally, they decrease the cover of willows. Over the long term, beaver activities create wetlands by raising the local water table adjacent to streams they have impounded.

Interactions: Heavy livestock grazing can degrade stream banks, which can affect local hydrology and lead to increased erosion of banks. Overgrazing of uplands can increase flash flooding of streams. Downcutting of the stream channel can occur if grazing has destabilized the banks. Downcutting lowers the water table causing a drying of adjacent riparian soils. Beavers can raise the water table, creating more wetland habitat.

Grazing reduces vegetal cover and fuels capable of carrying a fire through steppe vegetation. Less frequent fire in steppe results in less frequent non-lethal ground fires in Douglas-fir forest and 
reduced regenerating fire in aspen woodland. Reduced frequency of ground fires causes dense stocking and eventual stand-replacing crown fires.

\section{Plant species of concern}

Ten Plant Species of Concern occur in the East Centennial Mountains. Astragalus terminalis, Draba globosa, and Lesquerella pulchella are regional endemics found only or primarily in southwest Montana and adjacent Wyoming and Idaho. Aquilegia formosa, Balsamorhiza macrophylla, Carex multicostata, Haplopappus nanus, Penstemon whippleanus, Stellaria jamesiana and Viguiera multiflora are more widespread and common elsewhere but rare in Montana. Astragalus terminalis, Lesquerella pulchella and Penstemon whippleanus are listed as sensitive by BLM. Balsamorhiza macrophylla, Carex multicostata and Draba globosa are on the BLM watch list. All ten species occur in three types of habitat: riparian woodland/ forest, steppe and stony slopes (Culver 1993).

Riparian: Aquilegia formosa and Stellaria jamesiana occur in moist, open woodland or forest along streams. These habitats can be affected by livestock

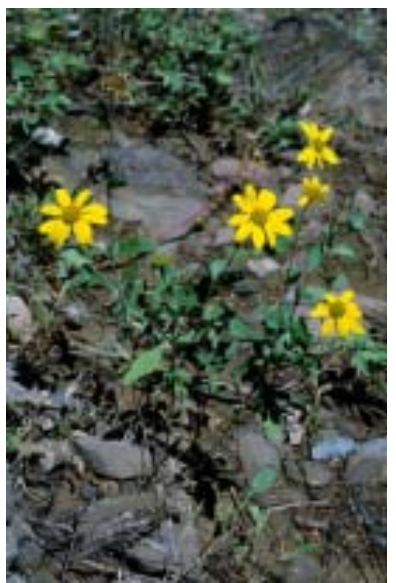

Viguiera multiflora, Beaverhead Co. grazing and beavers. They are too far upstream to be affected by stream diversions. Cattle are attracted to the shade and succulent vegetation of riparian areas in summer. The mesic understory vegetation of these habitats can be degraded by overgrazing. In the short term, beavers remove willows and aspen and flood riparian zones, resulting in a loss of shrubs. However, over the long term, beavers increase riparian habitat that supports these two plants.

Steppe: Grassland and sagebrush communities provide habitat for three rare plants: Astragalus terminalis, Balsamorhiza macrophylla and Carex multicostata. Fire and grazing are the important forces affecting sagebrush steppe. Disturbance from fire reduces competition from big sagebrush and could be important in maintaining the rare species. Cattle grazing generally favors broad-leaved forbs like Astragalus terminalis and Balsamorhiza macrophylla. However, graminoids such as Carex multicostata are usually palatable to cattle (Hermann 1970) and may decline in response to their grazing. Both A. terminalis and C. multicostata could be adversely affected by sheep grazing. Balsamorhiza macrophylla is probably too coarse to be preferred by either sheep or cattle.

Slope: Draba globosa, Haplopappus nanus, Lesquerella pulchella, Penstemon whippleanus and Viguiera multiflora grow in poorly developed soil with sparse vegetation on steep slopes or exposed ridge tops. Erosion and mining have an impact on this habitat. The first three species are low in stature, and presumably all of them are adapted to shallow soil and low levels of competition. Moderate levels of wind or water erosion are required to prevent soil development and larger plants from invading many of these habitats. However, steep habitats are prone to slope failure and massive erosion when impacted by road-building or other activity causing a large disturbance. Mining is unlikely in Madison limestone, but has occurred in a contact zone near the summit of Taylor Mountain. Draba globosa and L. pulchella could be adversely impacted by similar high-elevation mining. Steep slope and barren ridge top habitats receive little impact from livestock, and there is usually inadequate fuel to carry a fire. The Continental Divide Trail crosses through the lower end of the Lesquerella pulchella population in the mouth of Hell Roaring Canyon.

\section{Conservation significance}

The region encompassed by Beaverhead, Madison and Silver Bow counties has the greatest number of globally rare plants in Montana, and the East Centennial Mountains support populations of three of these 
globally rare species (G2-G3) that occur primarily in southwest Montana and adjacent Idaho and/or Wyoming: Astragalus terminalis, Draba globosa, and Lesquerella pulchella. The high-elevation form of Astragalus terminalis could be threatened by sheep grazing, but the latter three species all occur in remote, high-elevation habitats that are little threatened by human activities. The East Centennial Mountains also support seven plant species with a wider global distribution but considered rare in Montana. Aquilegia formosa, Balsamorhiza macrophylla, Carex multicostata, Haplopappus nanus, Penstemon whippleanus Stellaria jamesiana and Viguiera multiflora each have fewer than five known occurrences in Montana. Astragalus terminalis, Lesquerella pulchella and Penstemon whippleanus are listed as Sensitive by BLM. Balsamorhiza macrophylla, Carex multicostata and Draba globosa are on the BLM Watch list.

\section{Management}

Most of the East Centennial Mountains is roadless and is managed as de facto wilderness. Red Rock Lakes National Wildlife Refuge lands are managed as wilderness, and BLM lands are a wilderness study area. Weeds and livestock grazing pose the greatest risks to the area's biological values. Decommissioning roads and restricting ORV use in the Taylor Mountain and Sheep Mountain areas will help prevent erosion and weed introductions. There is also a continued need for weed control on the valley floor along the main roads, at traiheads, and along old logging roads on private land.

Adverse effects of livestock trampling and grazing of herbaceous vegetation on stream banks can be reduced by limiting grazing to the latter part of the summer in as many years as possible in riparian areas and aspen groves. Restoring willows (Salix planifolia, S. boothii, S. geyeriana) along creeks on the valley floor will reduce bank erosion and improve riparian hydrology. Management of sheep grazing on the crest of the range would be beneficial to prevent weed encroachment and population declines in the unusual alpine form of Astragalus terminalis.

Controlled burning of steppe vegetation might help create a healthy grassland-shrubland mosaic on the valley floor and foothills. Forest restoration practices such as thinning or underburning may be desirable at lower elevations in order reduce timber stocking and help prevent crown fires. Controlled burning may also benefit aspen stands. Reintroducing beavers could be a way to rejuvenate aspen groves as well as create wetlands and provide hydrologic stability to the valley water table. 


\section{Description}

\section{GRASSHOPPER CREEK}

The Grasshopper Creek area encompasses the geologically diverse southern spur of the Pioneer Range in central Beaverhead County. It includes the drainage of lower Grasshopper Creek Canyon between Bannack and the confluence with the Beaverhead River. Badger Pass is the northernmost point. The southern boundary is the Grasshopper-Horse Prairie Divide, and the west boundary is the Sagebrush Creek-Taylor Creek valleys. Elevations range from 5,500 ft along Grasshopper Creek to 7,400 ft of the low peaks in the Pioneer Range. Grasshopper Creek is the only permanent stream in the area. The Bannack area in the northwest portion of the site was an extensive mining district in the past. The old Bannack townsite is now a state historic park, and there is a campground just to the west. The area is subject to livestock grazing. Big game hunters use the area during hunting season.

\section{Geology and soil}

Parent materials in the Bannack-Grasshopper Creek area are diverse. The western portion is underlain by Madison limestone intruded by granodiorite and other granitics from the Pioneer batholith. Farther east the Paleozoic sedimentary rocks are overlain by volcanic andesite, tuff and basalt. The contact zone between limestone and granite is particularly diverse, and the associated soils vary from sandy loam to clay. Barren slopes with poorly developed soils are common. Ridge tops and upper slopes on Madison limestone often support only thin soil. Soils on steep slopes are poorly developed and often nearly barren. Evidence of rill and sheet erosion is commonly observed in these areas.

At least a dozen inactive mines occur on the slopes along Grasshopper Creek between Bannack and Cold Spring Creek. Grasshopper Creek has been dredged for much of its length, and berms of gravel line the banks in many areas. It appears that a small amount of mineral extraction activity still occurs near Bannack and the mouth of Cold Spring Creek.

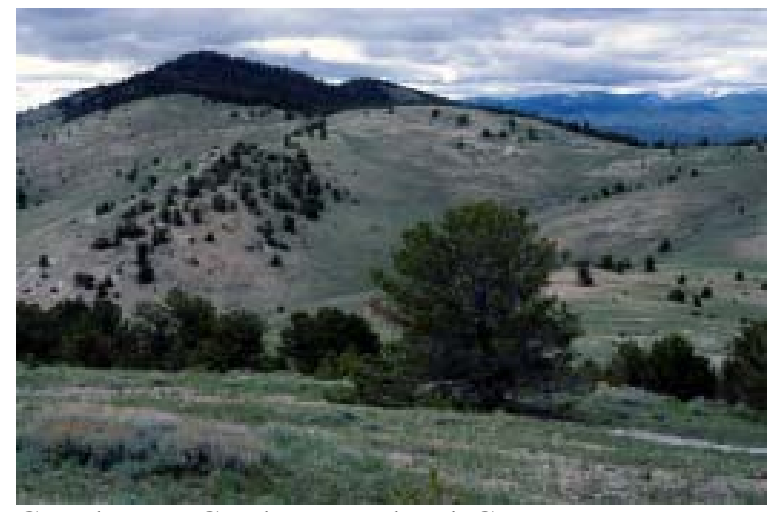

Grasshopper Creek, Beaverhead, Co.

\section{Vegetation}

Several types of Douglas-fir (Pseudotsuga menziesii) forest are associated with cooler slopes on the ridge of limestone that runs the length of the site from Badger Pass to south of Bannack. Warm slopes on this ridge with little soil development may support woodlands dominated by mountain mahogany (Cercocarpus ledifolius) and/or limber pine (Pinus flexilis). Sagebrush steppe is the most common vegetation of the Grasshopper Creek area. Artemisia tridentata ssp. vaseyana is dominant on lower and mid-slopes and other upland sites with well developed soil. Low

sagebrush (Artemisia nova and perhaps A. arbuscula) steppe occurs on warm slopes with limestonederived soil. Basin big sagebrush (Artemisia tridentata ssp. tridentata) is found on terraces along the larger drainages. Poorly developed soils of steep slopes and exposed ridge tops support bluebunch wheatgrass (Agropyron spicatum) grasslands with many different species of forbs, including cushion plants (Cooper et al. 1995).

Communities dominated by willow (Salix spp.) and alder (Alnus viridis) occur along Grasshopper Creek. These riparian habitats have been severely degraded by dredging and other mining activity. Cottonwood (Populus trichocarpa or P. angustifolia) forest is found along Grasshopper Creek in the vicinity of the Bannack townsite. Small examples of wetland plant communities dominated by Baltic rush (Juncus balticus) and Nebraska sedge (Carex nebrascensis) are associated with springs (Eli Spring). 


\section{GRASSHOPPER CREEK}

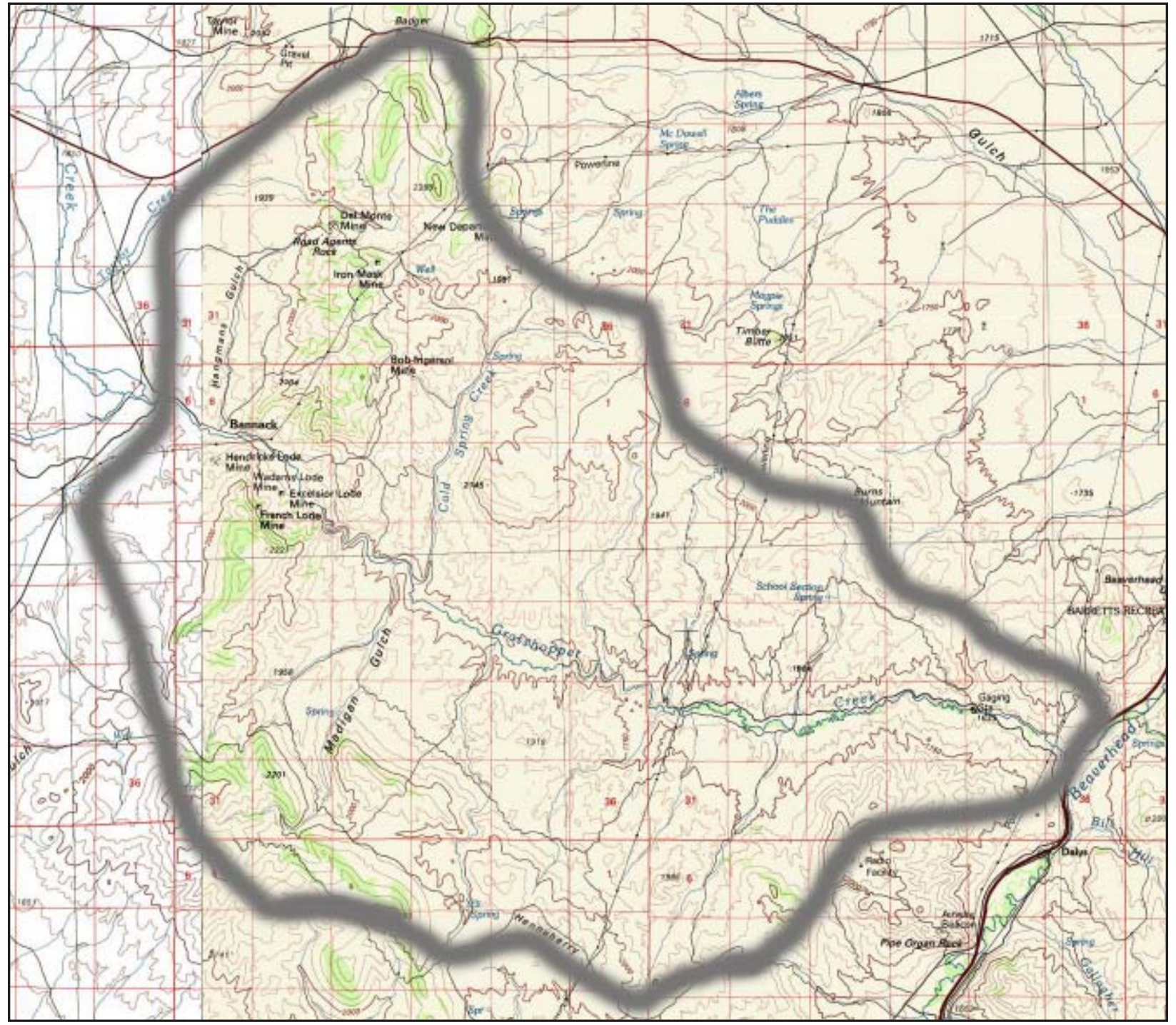




\section{Vegetation processes}

Upland vegetation dominates this area. These communities are influenced by fire, ungulate grazing and mineral extraction. Erosion plays an important role in structuring upland communities on steep slopes with poorly developed soils. Hydrologic events (i.e., flooding) and beavers played an important role in determining vegetation along Grasshopper Creek. Past (and present?) mining activity has severely altered riparian habitats.

Fire: Average fire-return intervals in steppe vegetation in the high valleys of southwest Montana were likely less than 25-50 years prior to European settlement (Arno and Gruell 1983). However, much of the slope vegetation of the Grasshopper Creek site is too sparse and unproductive to carry a fire under all but extremely unusual circumstances. Fires may have ignited in dense stands of sagebrush only to burn out on upper slopes or ridge tops. Occasional catastrophic crown fires would have occurred in the dense stands of Douglas fir found on steep, north-facing slopes, reducing them to open stands of shrubs such as snowberry and chokecherry. Mountain mahogany woodlands have very little fuel in the ground layer and probably did not often burn. Fires probably had little effect on the riparian communities. Therefore it seems likely that fire was only a minor force in shaping the vegetation of this area.

Grazing: Livestock grazing has occurred in Beaverhead County for more than 100 years. Much of the terrain of the Grasshopper Creek area is steep, and reliable sources of water are found only along Grasshopper Creek, springs in the eastern portion of the site, and water developments at the head of Sagebrush Creek. Effects of livestock grazing were most apparent at spring sites, along the wider drainage bottoms, and the more gentle terrain east of the Madigan Gulch-Cold Spring Creek axis. Grazing by cattle is expected to lower the abundance of palatable grasses with a concomitant increase in broadleaf forbs. It is assumed that livestock grazing caused the observed low abundance of grass in basin big sagebrush stands along Madigan Gulch. Steppe communities of gentle slopes in the Henneberry Ridge area had less Idaho fescue (Festuca idahoensis) than expected, perhaps due to livestock grazing. It also appears that livestock have caused hummocking of wetland soils and perhaps a loss of tufted hairgrass (Deschampsia cespitosa) around Eli Spring.

Livestock can introduce invasive, exotic plants into the site. Spotted knapweed (Centaurea maculosa) probably occurs around Bannack State Park and the north portion of the Grasshopper Creek site. It is likely that knapweed would thrive in the stony soils of the site.

The mountain mahogany woodlands on the warm, lower-elevation slopes in the western part of the area provides excellent winter habitat for mule deer. Deer are undoubtedly affecting the growth and structure of mountain mahogany plants; however, many of the plants are higher than the browse line and are suffering minimal damage from deer.

Mineral extraction: At least a dozen mines occur along the contact zones between Madison Limestone and granitic intrusions of the Pioneer batholith, particularly in the vicinity of Bannack at the top of Grasshopper Creek Canyon. Roads associated with these mines are common throughout the western portion of the area. Roads, especially on steep slopes with sparse vegetation, can cause soil erosion and may also be the means by which invasive exotic plants are introduced. Dredging of Grasshopper Creek has drastically altered the banks and riparian zone throughout most of the canyon. Large berms of bare rock and gravel channelize the creek and prevent establishment of willows and alders. Old roads occupy much of the narrow, now inactive floodplain in portions of the canyon.

Erosion: Soils derived from metasediments (and possibly volcanics) on steep slopes are found throughout much of the site. These slopes are sparsely vegetated with highly erodible, bare soil. Sheet and rill erosion is evident throughout the area. This erosion is natural but is exacerbated by disturbance from motorized vehicles. Many of the intermittent streams in the area have channels that are downcut well 
below adjacent terraces. Much of this erosion is due to flash flooding in terrain that is steep and poorly vegetated.

Hydrology: Maintaining riparian vegetation over the long term depends on periodic flooding associated with natural snowmelt-driven hydrologic regimes. Diversions in the upper Grasshopper Creek Valley probably have little effect on spring flooding but may lower water levels during summer months.

Beavers: Beavers were undoubtedly present on Grasshopper Creek at some times in the past. Beavers destroy the dominant cottonwood while creating ponds and wetlands. It is not known wether beavers currently occur along Grasshopper Creek.

Process interactions: Under most circumstances, livestock use of barren slopes will be minimal. Sparsely vegetated slopes will not produce enough fuel to carry a fire. The most likely cause of increased erosion in the uplands will be human disturbance such as mining activity or off-road vehicle use. Bank erosion and downcutting along intermittent streams can occur as a result of vegetation loss due to livestock grazing or road building.

\section{Plant species of concern}

Nine Plant Species of Concern occur in the Grasshopper Creek area (Vanderhorst 1995c, Heidel and Vanderhorst 1996). Astragalus scaphoides, Astragalus terminalis, Lesquerella pulchella, Lomatium attenuatum and Penstemon lemhiensis are regional endemics, found only in southwest Montana and adjacent Idaho and/or Wyoming. In addition, recent research indicates that Erigeron parryi, a local endemic of southwest Montana, occurs in the area. Three other species, Allium parvum, Sphaeromeria argentea and Taraxacum eriophorum, are more

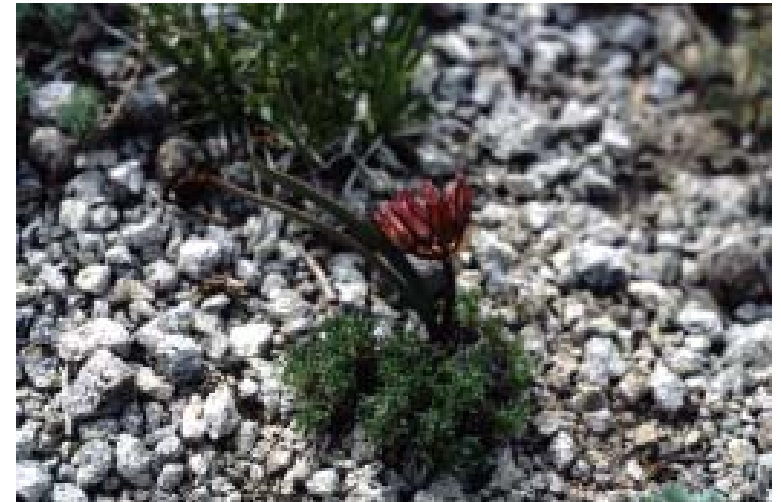

Allium parvum, Beaverhead Co. widespread and common elsewhere but rare in Montana. Astragalus scaphoides, Astragalus terminalis, Lesquerella pulchella, Lomatium attenuatum, Penstemon lemhiensis, Sphaeromeria argentea and Taraxacum eriophorum are listed as sensitive by BLM. All nine species occur in three types of habitat: wetlands, sagebrush steppe and stony slopes.

Wetlands: Taraxacum eriophorum occurs in moist soil of meadow habitats associated with springs and headwaters streams. These habitats can be affected by livestock grazing. However, species of Taraxacum flower early and are low to the ground. Like many broad-leaved plants they increase with disturbance and reduced competition from the dominant graminoids. All but the heaviest levels of livestock grazing are likely to be beneficial to this plant.

Steppe: Astragalus scaphoides, Astragalus terminalis and Penstemon lemhiensis and are found in sagebrush steppe. Fire and grazing are the two important forces affecting this widespread habitat. Disturbance from fire reduces competition from sagebrush and is important in maintaining Penstemon lemhiensis populations (Heidel and Shelly 2001). It is likely that fire enhances population viability for Astragalus scaphoides and Astragalus terminalis as well. Livestock grazing generally favors broadleaved forbs at the expense of graminoids. Although cattle do remove the tops of A. scaphoides plants in some years, it does not have an adverse effect on population growth (Lesica 1995). Astragalus terminalis is morphologically similar to A. scaphoides and probably responds to grazing in a similar manner. Disturbance from livestock grazing is not likely to adversely affect $P$. lemhiensis because it 
responds positively to soil disturbance (Shelly 1987). Rare plant populations in sagebrush steppe could be negatively impacted by new roads associated with mining activity.

Slope: Lomatium attenuatum, Lesquerella pulchella, Sphaeromeria argentea, Erigeron parryi and Allium parvum occur on exposed slopes and ridge tops with minimal soil development and sparse vegetation. Erosion and mining activity have the greatest impacts on this habitat. All species are low in stature, and presumably all of them are adapted to shallow soil and low levels of competition. Moderate levels of wind or water erosion are required to prevent soil development and larger plants from invading many of these habitats. However, these habitats are prone to slope failure and massive erosion when impacted by road-building or other activity causing a large disturbance. Mining is unlikely in Madison limestone, but is common in the metasediments near the mouth of the canyons in the west part of the site. Steep slope and barren ridge top habitats receive little impact from livestock, and there is usually inadequate fuel to carry a fire.

\section{Conservation significance}

The region encompassed by Beaverhead, Madison and Silver Bow counties has the greatest number of globally rare plants in Montana, and Grasshopper Creek has one of the highest concentrations of these endemic plants in southwest Montana. The Grasshopper Creek area supports metapopulations of five globally rare species (G1-G3) that occur only in southwest Montana and adjacent Idaho and/or Wyoming: Astragalus scaphoides, Astragalus terminalis, Lesquerella pulchella, Lomatium attenuatum and Penstemon lemhiensis. This site harbors Montana's largest metapopulations of three of these regional endemics: A. scaphoides, L. pulchella and L. attenuatum. Astragalus scaphoides has been found in 27 sections here with a total of at least 30,000 plants. Lesquerella pulchella, a Montana endemic, has been found in 9 sections totaling about 20,000 plants. Lomatium attenuatum has been found in 14 sections within the area, totaling about 20,000 plants. In addition, there is a population of about 1,000 plants of Erigeron parryi on BLM land with many thousands more believed to be on adjacent private land.

Grasshopper Creek also encompasses populations of three plant species with a wider global distribution but considered rare in Montana: Allium parvum, Sphaeromeria argentea and Taraxacum eriophorum. The site has a large metapopulation (about 10,000 plants) of Sphaeromeria argentea over at least seven sections. The population of Allium parvum that occurs here in unusual calcareous soil is the northeastern-most recorded site for this species. Seven of the plant species at this site are designated BLM Sensitive: Astragalus scaphoides, Astragalus terminalis, Lesquerella pulchella, Lomatium attenuatum, Penstemon lemhiensis, Sphaeromeria argentea and Taraxacum eriophorum.

\section{Management}

Most of the Grasshopper Creek area is public land, managed primarily by BLM, Montana Fish Wildlife and Parks, and Montana Natural Resources and Conservation. Significant privately-owned parcels occur along Grasshopper Creek and along the ridge between Bannack and Badger Pass. The southern portion of the site is a BLM wilderness study area. Some of the most sensitive areas have a high density of roads, many on steep slopes and some on highly erodible soils. Erosion and habitat degradation can be reduced or prevented by closing and reclaiming these roads when possible, restricting off-road vehicle use, and carefully regulating mining activity.

Perhaps the most serious threat to the vegetation and sensitive species of the Grasshopper Creek site is invasion of exotic weeds, particularly spotted knapweed (Centaurea maculosa). Spotted knapweed has become common along roads southeast of Badger Pass and in the vicinity of Bannack. It flourishes in stony soil, the same habitat that supports many of the globally rare plants. Vehicles and roads appear to facilitate knapweed invasion, and road closures may be critical to preventing continued 
introductions into wildland habitats. Where roads remain open, annual surveys and eradication along roadsides, especially those with frequent use, would also be beneficial.

Basin big sagebrush steppe on terraces of Grasshopper Creek and larger intermittent drainages often has a degraded ground layer with low cover of western wheatgrass (Agropyron smithii) and basin wildrye (Elymus cinereus). Better management of livestock grazing may result in improved conditions. The riparian area along Grasshopper Creek below Bannack is in extremely poor condition. Channel and bank restoration would allow riparian vegetation to re-establish, leading to enhanced wildlife habitat.

\section{Further research}

The 2-3 mile-wide corridor along Grasshopper Creek below Cold Spring Creek is mainly private land and has not been surveyed for sensitive plants or plant communities. 


\section{Description}

\section{JOHNSON GULCH}

Johnson Gulch lies on the west side of the Tendoy Range in southern Beaverhead County. This area is bounded on the west by Medicine Lodge Creek and on the east by the crest of the Tendoy Mountains and includes the entire drainages of Deer Creek, Johnson Gulch and Kissick Canyon. Elevations range from 6,150 ft along Medicine Lodge Creek to 8,500 ft on the crest of the Tendoys. Johnson Gulch and Deer Creek have permanent surface water in their upper reaches but are intermittent lower down. Poison Lakes, two small natural water bodies occur just west of the Tendoy crest at 8,100-8,300 ft in elevation. The upper lake has a broad drawdown zone and appears to be fed primarily by snowmelt and other surface runoff. The lower lake has a stable water level and must be fed by underground springs, possibly originating at the upper lake. The lower lake has a broad band of floating peat separating the shore from open water.

There has been mining activity in the western portion of the site. The subirrigated area along Medicine Lodge Creek is used for hay production. The area is subject to livestock grazing and Big game hunters use it during hunting season.

\section{Geology and soil}

The Tendoy Range is composed primarily of Paleozoic and Mesozoic sedimentary formations tilted and uplifted along the Red Rock fault on the east side of the range. There are extensive exposures of Madison limestone forming cliffs and talus slopes in the three canyons. Fine-textured sediments, metasediments or possibly volcanics outcrop at lower elevations just east of Medicine lodge Creek. There is an inactive mine at the mouth of Deer Creek Canyon on the north side. Mining claims are common south of Deer Creek Canyon and on the crest of the Tendoys.

Soils are variable. They are deep and productive at the head of drainages and in the more gentle topography near the Tendoy crest. Soils associated with limestone outcrops are generally shallow. Soils on steep slopes in the western portion of the area are poorly developed and often nearly barren. Evidence of rill and sheet erosion is commonly observed in this area.

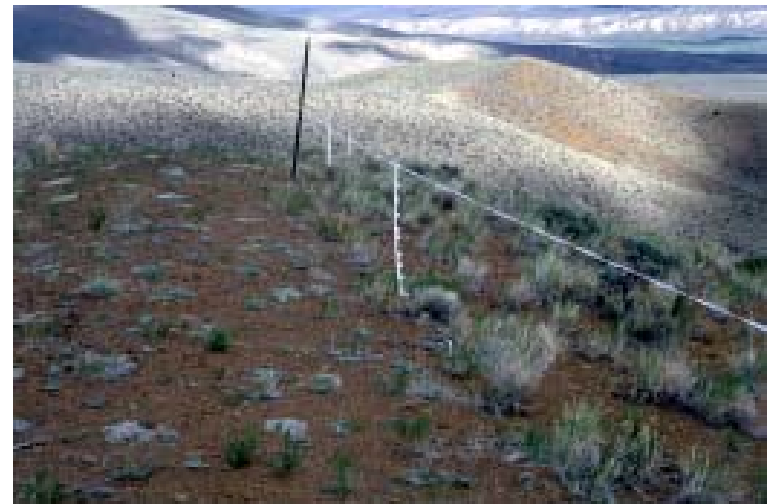

Johnson Gulch area, Beaverhead Co.

\section{Vegetation}

Johnson Gulch supports a mosaic of steppe, woodland and forest communities (Cooper et al. 1995). Gentle slopes over 7,000 ft on well-developed soils support sagebrush steppe, the Artemisia tridentata vaseyana/ Festuca idahoensis community type. This is the dominant zonal vegetation of the site. Lower slopes near the Medicine Lodge Valley support steppe of the Artemisia tridentata wyomingensis/Agropyron spicatum community type. Douglas-fir (Pseudotsuga menziesii) forest occurs on north-facing canyon walls. Mountain mahogany (Cercocarpus ledifolius) woodlands are found on steep, warm slopes with poorly developed soil, especially on limestone. Low sagebrush steppe (Artemisia nova and A. arbuscula) is uncommon and found on shallow, limestonederived soils of exposed upper slopes. Subirrigated terraces along Medicine Lodge Creek (and other drainages to a minor extent) support wet meadows dominated by Deschampsia cespitosa or Juncus balticus/Carex praegracilis community types. Associated toeslopes and upper terraces support greasewood, the Sarcobatus vermiculatus/Distichlis stricta community type. Wet peat around lower Poison Lake supports poor fen vegetation dominated by Carex utriculata, Menyanthes trifoliata and Urticularia vulgaris. 
JOHNSON GULCH

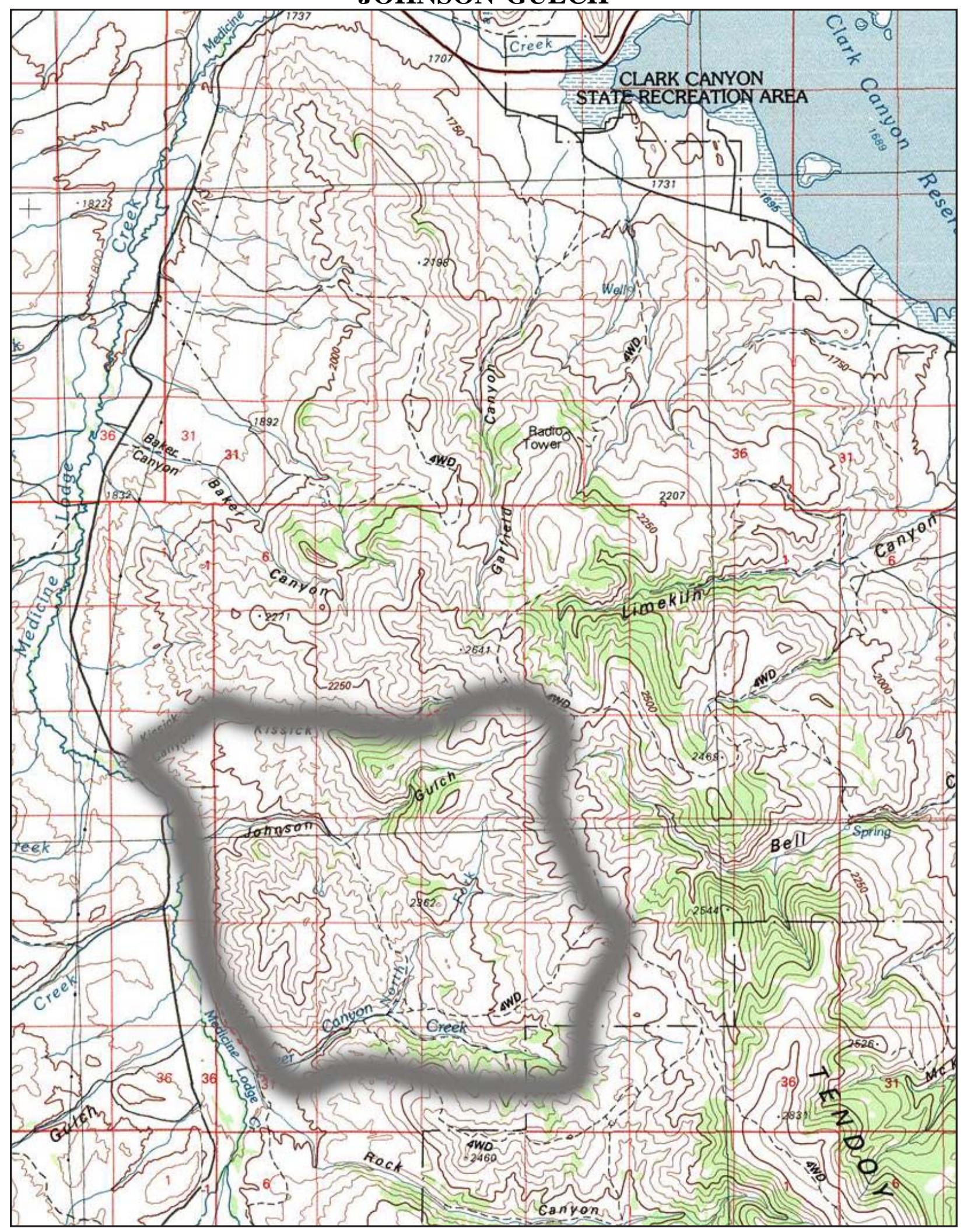




\section{Vegetation processes}

Upland vegetation dominates this site. These communities are influenced by fire, ungulate grazing and mineral extraction. Erosion plays an important role in structuring upland communities on steep slopes with poorly developed soils. Wetland communities associated with Poison Lakes, Medicine Lodge Creek and headwaters of smaller drainages can be influenced by altered hydrologic regimes.

Fire: Average fire-return intervals in steppe vegetation in the high valleys of southwest Montana were likely less than 25-50 years prior to European settlement (Arno and Gruell 1983). These fires caused a mosaic of severely to lightly burned patches and reduced the cover of sagebrush which is easily killed by fire and often requires in excess of ten years to reestablish preburn stature and density. Occasional catastrophic crown fires would have occurred in the dense stands of Douglas fir found on steep, northfacing slopes, reducing them to open stands of shrubs such as snowberry and chokecherry. Mountain mahogany woodlands have very little fuel in the ground layer and probably did not often burn. Fires probably had little effect on the herbaceous wetland communities.

Grazing: Livestock grazing has occurred in southern Beaverhead County for more than 100 years. All of the Johnson Gulch site except hay meadows along Medicine Lodge Creek are in grazing allotments. However, much of the terrain is steep, and reliable sources of water are found only at the head of drainages over 7,500 ft. Effects of livestock grazing are apparent only along the wider stream bottoms and the gentle crest of the Tendoy Range, especially around Poison Lakes and the small streams and ponds just below.

The extensive mountain mahogany woodlands on the warm, lower-elevation slopes of the Johnson Gulch site provide excellent winter habitat for mule deer. The ground was covered several centimeters deep in deer pellets on the slopes just south of the mouth of Johnson Gulch canyon. Deer are undoubtedly affecting the growth and structure of mountain mahogany plants; however, a large proportion of plants are above the browse line.

Livestock can introduce invasive, exotic plants into the site. Currently, noxious weeds are not known to be present, but spotted knapweed (Centaurea maculosa) has been found around Clark Canyon Reservoir just northeast of the site. It is likely that knapweed would thrive in the stony soils of the site.

Mineral extraction: An old mine occurs on the north side of Deer Creek just west of the canyon mouth. Old roads were made on steep, south-facing slopes in talus and poorly developed soils. Numerous mining claims are found along the crest of the Tendoy Range and on the ridge south of Deer Creek Canyon. This mining activity is probably responsible for many of the two-track roads found in the area. Roads, especially on steep slopes, can cause soil erosion and may also be the means by which invasive exotic plants are introduced.

Erosion: Soils derived from metasediments (and possibly volcanics) on steep slopes are found in the west half of the site. These slopes are sparsely vegetated with a high degree of bare soil. Sheet and rill erosion is evident throughout the area. This erosion is natural but is exacerbated by disturbance from motorized vehicles.

Hydrology: Wet meadows along Medicine Lodge Creek depend on water moving out of the creek and saturating low terrace soils. The extent, productivity and species composition of these meadows will depend on water levels in the creek which can be influenced by diversions and impoundments in the upstream watershed as well as climate. Wetland vegetation associated with Poison Lakes and headwaters springs depends, in part, on groundwater, both shallow and deep, originating with the highelevation snowpack. Mining activity, roads and water developments can alter groundwater flows and cause changes in wetland vegetation.

Appendix C - 31 
Process interactions: Under most circumstances, livestock use of barren slopes will be minimal. Sparsely vegetated slopes will not produce enough fuel to carry a fire. The most likely cause of increased erosion will be human disturbance such as mining activity or off-road vehicle use. These same activities, along with water development for livestock, are also the ones most likely to alter local hydrologic regimes.

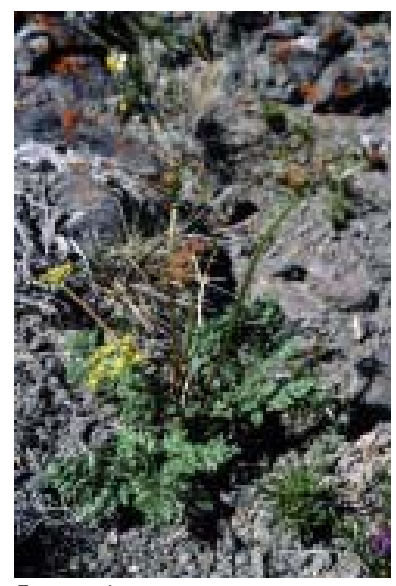

Lomatium attenuatum, Beaverhead Co.

\section{Plant species of concern}

Eight Plant Species of Concern occur in Johnson Gulch (Vanderhorst and Lesica 1994, Vanderhorst 1995a). Astragalus scaphoides, Carex idahoa, Lomatium attenuatum, Penstemon lemhiensis and Thlaspi parviflorum are regional endemics, found only in southwest Montana and adjacent Idaho and/or Wyoming. All but Thlaspi parviflorum are listed as sensitive by BLM. Draba densifolia, Kochia americana and Phacelia incana are more widespread but rare in Montana. Phacelia incana is on BLM's Watch List. These nine species occur in three types of habitat: wetlands, sagebrush steppe and stony slopes.

Wetlands: Carex idahoa and Kochia americana occur in moist soil of meadow habitats on the dry margin of wetlands. These habitats can be affected by livestock grazing and alteration of hydrologic regime. Carex idahoa is found around the outlet of Lower Poison Lake. Livestock grazing is high in this area because there is water, and the meadow fringe where this sedge occurs is often highly impacted. Carex idahoa is palatable to livestock (Hermann 1970) and expected to decline with heavy grazing pressure (Lesica 1998). Furthermore, heavy grazing promotes an increase in Kentucky bluegrass (Poa pratensis) which may compete with C. idahoa. Subsurface water flows feeding Lower Poison Lake could be adversely affected by further road building in the area. Kochia americana is found on private land along Medicine Lodge Creek in the salty fringe of the wet meadows where they merge into greasewood thickets. This plant is probably not very palatable to livestock, and trampling is probably not a serious threat because the meadows are usually cut for hay and not grazed until later in the season. Alteration of stream flows could affect the adjacent water table and adversely affect this plant's habitat.

Sagebrush: Astragalus scaphoides, Penstemon lemhiensis and Thlaspi parviflorum are found in sagebrush steppe. Fire and grazing are the two important forces affecting this widespread habitat. Disturbance from fire reduces competition from sagebrush and is important in maintaining Penstemon lemhiensis populations (Heidel and Shelly 2001). It is likely that fire enhances population viability for Astragalus scaphoides and Thlaspi parviflorum as well. Livestock grazing generally favors broadleaved forbs at the expense of graminoids. Although cattle do remove the tops of $A$. scaphoides plants in some years, it does not have an adverse effect on population growth (Lesica 1995). Disturbance from livestock grazing is not likely to adversely affect $P$. lemhiensis or $T$. parviflorum because the former responds positively to soil disturbance (Shelly 1987), and the latter is a very small plant likely to benefit from removal of dominant grass canopy. Rare plant populations in sagebrush steppe could be negatively impacted by new roads associated with mining activity.

Slope: Draba densifolia, Lomatium attenuatum and Phacelia incana occur on steep slopes with minimal soil development and sparse vegetation. Erosion and mining activity will have the greatest impacts on this habitat. All species are low in stature and presumably all of these plants are adapted to shallow soil and low levels of competition. Naturally low levels of erosion are required to prevent larger plants from invading these habitats. However, these habitats are prone to slope failure and massive erosion when impacted by road-building or other activity causing a large disturbance. Mining is unlikely in

\footnotetext{
Appendix C - 32
} 
Madison limestone, but is common in the metasediments near the mouth of the canyons in the west part of the site. Steep slope habitat is little influenced by fire or grazing.

\section{Conservation significance}

The region encompassed by Beaverhead, Madison and Silver Bow counties has the greatest number of globally rare plants in Montana, and Johnson Gulch has a high concentration of these endemic plants. Johnson Gulch supports metapopulations of five globally rare species (G1-G3) that occur only in southwest Montana and adjacent Idaho and/or Wyoming: Astragalus scaphoides, Carex idahoa, Lomatium attenuatum, Penstemon lemhiensis, and Thlaspi parviflorum. Johnson Gulch has the second largest metapopulation of Lomatium attenuatum. However, populations of Astragalus scaphoides, Carex idahoa, Penstemon lemhiensis and Thlaspi parviflorum are relatively small. The site also encompasses populations of three plant species with a wider global distribution but considered rare in Montana: Draba densifolia, Kochia americana and Phacelia incana. Four of the globally rare species are listed as Sensitive by BLM, and Phacelia incana is on the Watch List.

In addition to supporting a population of Carex idahoa, Lower Poison Lake is noteworthy for being one of the highest fens $(8,100 \mathrm{ft})$ in Montana. Although the vascular vegetation is not diverse, this unusual fen may harbor rare invertebrates or ecotypes of common species. Small examples of low sagebrush communities dominated by Artemisia arbuscula occur in this site; they are uncommon in Montana and restricted to southern Beaverhead County.

\section{Management}

Two sections of the Johnson Gulch area are managed by the Montana Department of Natural Resources and Conservation, with portions along Medicine Lodge Creek and Kissick Canyon in private ownership. Part of the area managed by BLM is a wilderness study area. Many of the two-track roads are on steep slopes, and some are built on highly erodible soils. Closure of some roads and restriction of off-road vehicle use would help prevent erosion and the introduction of weeds. Any mining activity could cause erosion and habitat degradation unless strictly regulated. Prescribed fire may be introduced to create a habitat mosaic if natural fires do not occur. Monitoring of the intensity of livestock grazing around Lower Poison Lake is recommended to ensure that the population of Carex idahoa is not negatively impacted. 


\section{RAPE CREEK}

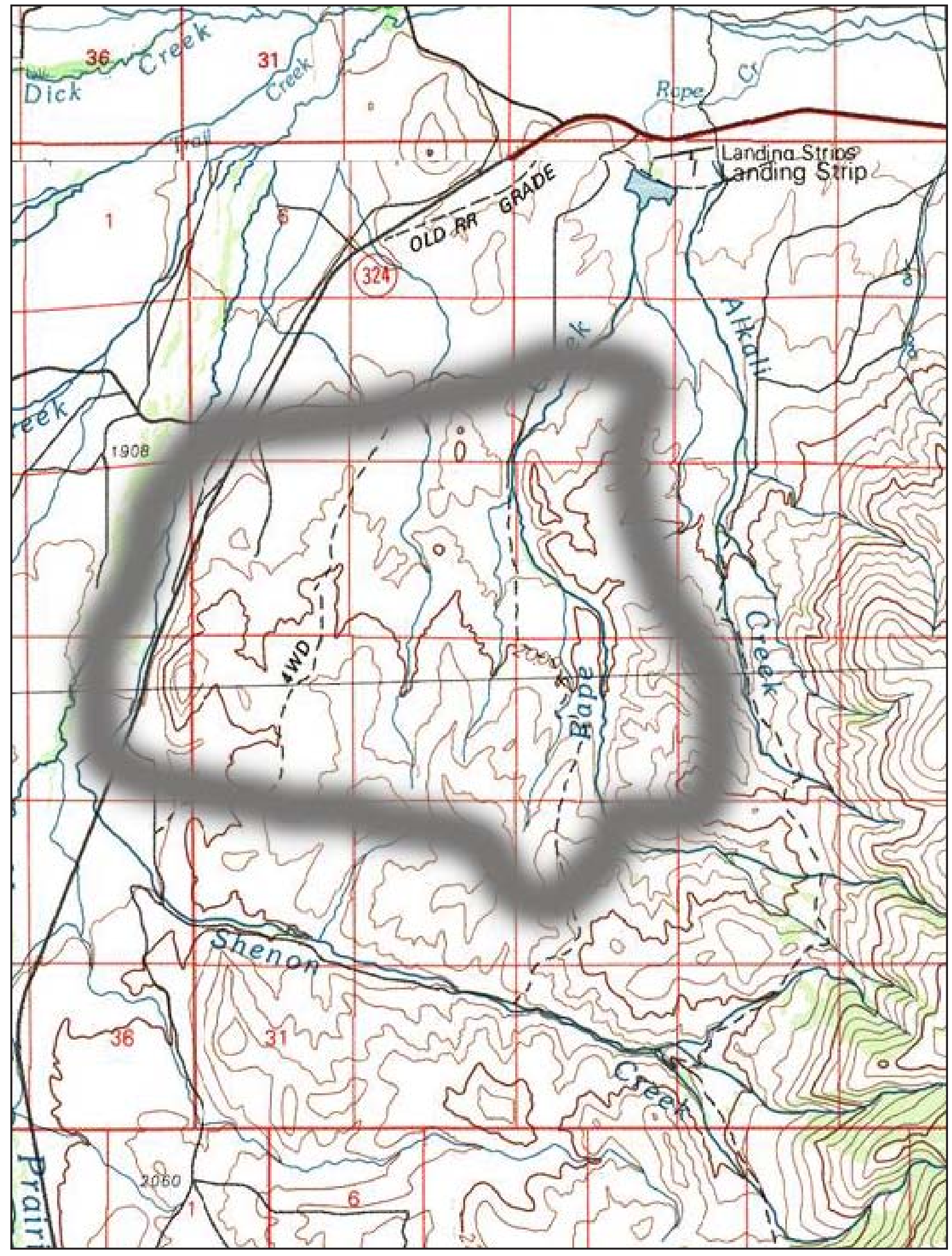




\section{Description}

\section{RAPE CREEK}

The Rape Creek area consists almost entirely of low, rounded hills and broad ridges interspersed with local outcrops of ashy shale slopes and Challis Volcanics. This area is bound by Horse Prairie Creek on the west and the gentle alluvial fans in private ownership to the north. The Rape Creek-Alkali Creek divide forms the east boundary, while the Rape Creek-Shenon Creek divide forms the south boundary. Rape Creek drains the area and flows north into Horse Prairie Creek. The Maidenhead spur of the Beaverheads lies to the east, while the main line of the Beaverheads lies to the south and west. Elevation ranges between 6,300 to 6,800 feet. The area is periodically used for livestock grazing.

\section{Geology and Soils}

Except for the ashy, coarse clay slopes derived from shale outcrops in the area, the soils are almost entirely extremely gravelly loams derived mostly from calcareous Beaverhead Conglomerates. Challis Volcanics are exposed in two areas, one close to Horse Prairie Creek on the west end of the site and the other in narrow ravines along Rape Creek.

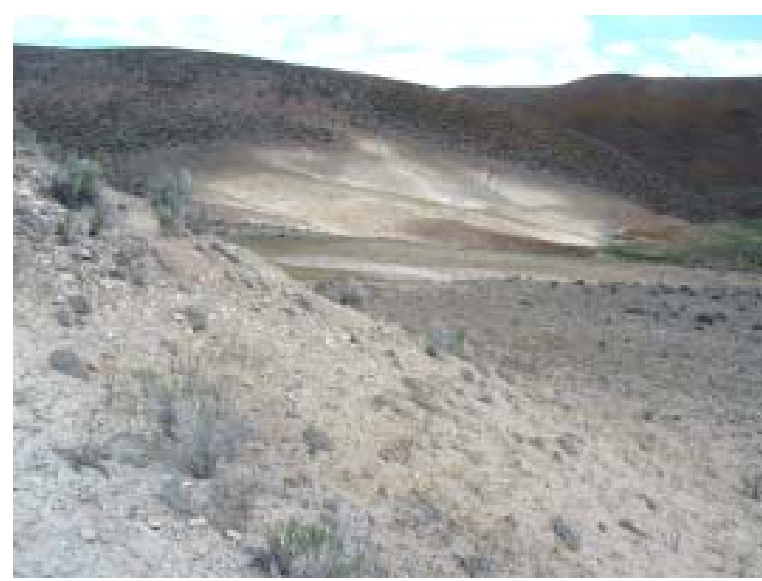

Rape Creek, Beaverhead Co.

\section{Vegetation}

Vegetative cover throughout nearly all the area is composed of Artemisia tridentata ssp. wyomingensis, Phlox muscoides, Chrysothamnus nauseosus and Gutierrezia sarothrae with scattered forbs and bunchgrasses. There is a narrow riparian stringer along Rape Creek consisting of mostly Salix exigua and Betula occidentalis.

\section{Vegetation Processes}

Upland vegetation dominates this site. These communities are influenced by fire and livestock grazing. Erosion plays an important role in structuring upland communities on steep slopes with poorly developed

soils. Hydrologic events (i.e., flooding) played a role in determining vegetation along Rape Creek.

Fire: Throughout most of the Rape Creek area, vegetation and fuel buildup are so sparse as to disallow hot, widespread fires. Prior to fire suppression, fire may have provided periodic, local disturbance and triggered regeneration (and possibly successional) processes. The stream terrace woodland along Rape Creek was probably free of extensive fire disturbance due to its narrow geometry and its normally hydrated condition.

Grazing: Livestock grazing has likely occurred in the Rape Creek area for at least 100 years. The nearby meadows of Horse Prairie creek are mostly either converted to pasture grasses, or are cultivated as hay fields. Livestock grazing on the uplands in the study area has apparently been light throughout. It appears that palatable forage may not have been abundant in the area from the time livestock grazing was first introduced, so the presence of cattle has probably been sporadic throughout that time. The scattered bunchgrasses in the local vegetation are mostly ungrazed. Native grazers only lightly browse in a diffuse manner and so are probably not a source of disturbance and regeneration.

Erosion: Evidence of erosion is often present wherever there are steep slopes or stream channels, preventing soil development and the presence of dense vegetation. Wind erosion, prevalent on exposed 
upper slopes and ridge crests, maintains the skeletal nature of the soil and promotes the existence of distinctive plant communities.

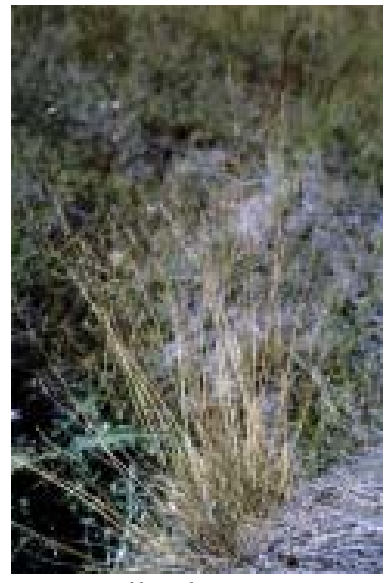

Puccinellia lemmonii

\section{Plant Species of Concern}

Rape Creek is the only verified Montana location for Eriogonum soliceps, a newly described local endemic. In addition, three plant Species of Concern, Plagiobothrys leptocladus, Puccinellia lemmonii and Sphaeromeria argentea grow in the Rape Creek area. Sphaeromeria argentea is listed as BLM Sensitive, and Plagiobothrys leptocladus is on the Watch list.

Wetland habitats Plagiobothrys leptocladus grows in a periodically desiccated stock pond in an intermittent tributary of Rape Creek in section 17 of T10S R13W. The Plagiobothrys is scattered on the pond floor in areas of very sparse cover of competing graminoids such as Hordeum jubatum and Eleocharis palustris. Given the artificial habitat, this population could conceivably be nonnative, perhaps having been introduced on cattle brought in from regions west of the Rocky Mountains. However, the Plagiobothrys population extends some distance along the creek beyond the margins of the stock pond. Also, there are few invasive species present in the Rape Creek area, and few nonnative species near the stock pond.

A population of Puccinellia lemmonii grows in a small, intermittent alkaline spring in the drainage of an unnamed intermittent creek in Section 19 of T10S R13W. It grows on strongly alkaline/salty clay slightly sloped down toward the creek. It occurs with Puccinellia nuttalliana, so there is some chance that this population represents historical hybridization with that species.

Steppe habitats One Species of Concern, Sphaeromeria argentea grows in the steppe habitats that cover most of the Rape Creek area. It occurs in diffuse patches with Phlox muscoides on gravelly ridgetops where Artemisia tridentata cover is relatively light. No damage from grazing was noticed in the population.

Eriogonum soliceps, first discovered in Idaho at Bannock Pass, grows on ashy, course clay slopes derived from degraded shale in a wide area of the study site, mostly in Sections 17 and 20 of T10S R13W. Rape Creek is the first extant population known in Montana. The Rape Creek population is larger than the type locality in Idaho, and is therefore the largest extant site currently known for the species.

\section{Conservation Significance}

Rape Creek supports the largest known population of Eriogonum soliceps, a newly discovered species that appears to be endemic to Beaverhead and (perhaps) Madison counties, Montana and adjacent Lemhi County, Idaho. It is currently known from only two sites, although it is likely that others exist. Three Montana Species of Concern occur within the Rape Creek area. Plagiobothrys leptocladus is common in limited areas of the western Great Basin and Columbia Basin, but is rare and scattered elsewhere. Puccinellia lemmonii is found mostly in the Great Basin and is scattered elsewhere in the West. It is rare except in small portions of its range. Sphaeromeria argentea is distributed in three widely separated centers in the Rocky Mountains and Great Basin, and is not common anywhere in its range. The small wetlands in this area, especially the alkali spring in section 19 and alkali flats along intermittent creeks, are in good condition with almost entirely native vegetation. The extensive steppe habitat also appears to be in good condition.

Appendix C - 36 


\section{Management}

Maintenance of the biological diversity and rare species in this area may depend on continued light livestock grazing. Continued grazing of wetlands should help maintain habitat for Plagiobothrys leptocladus, which requires open mud flats and is intolerant of competition from taller and rhizomatous graminoids. The open, clay slopes are attractive for ATV recreation, which would damage rare plants and increase erosion. 


\section{Appendix D. Locations of Areas SurVeyed Listed by U.S.G.S. QUAD NAME}



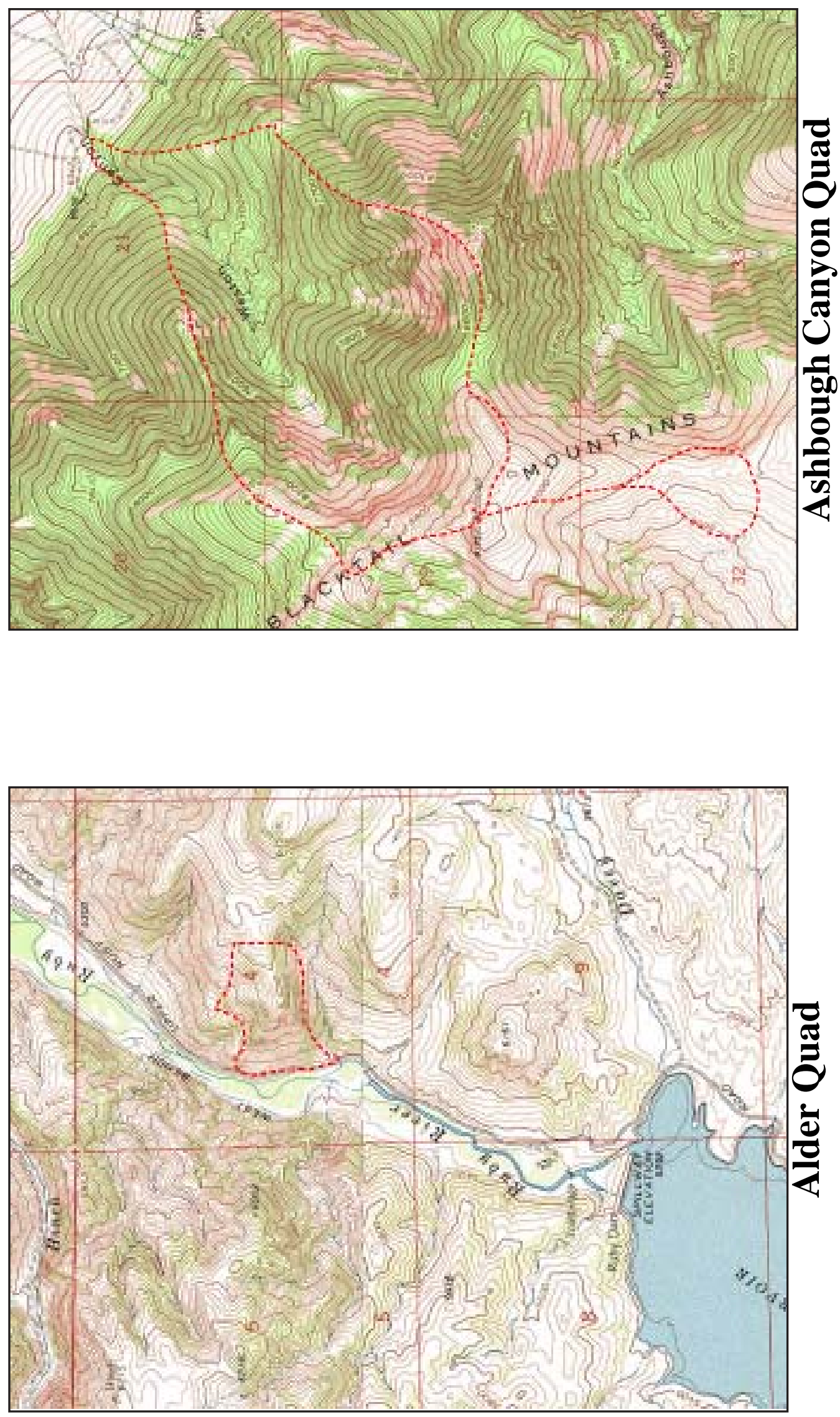

Appendix D - 1 

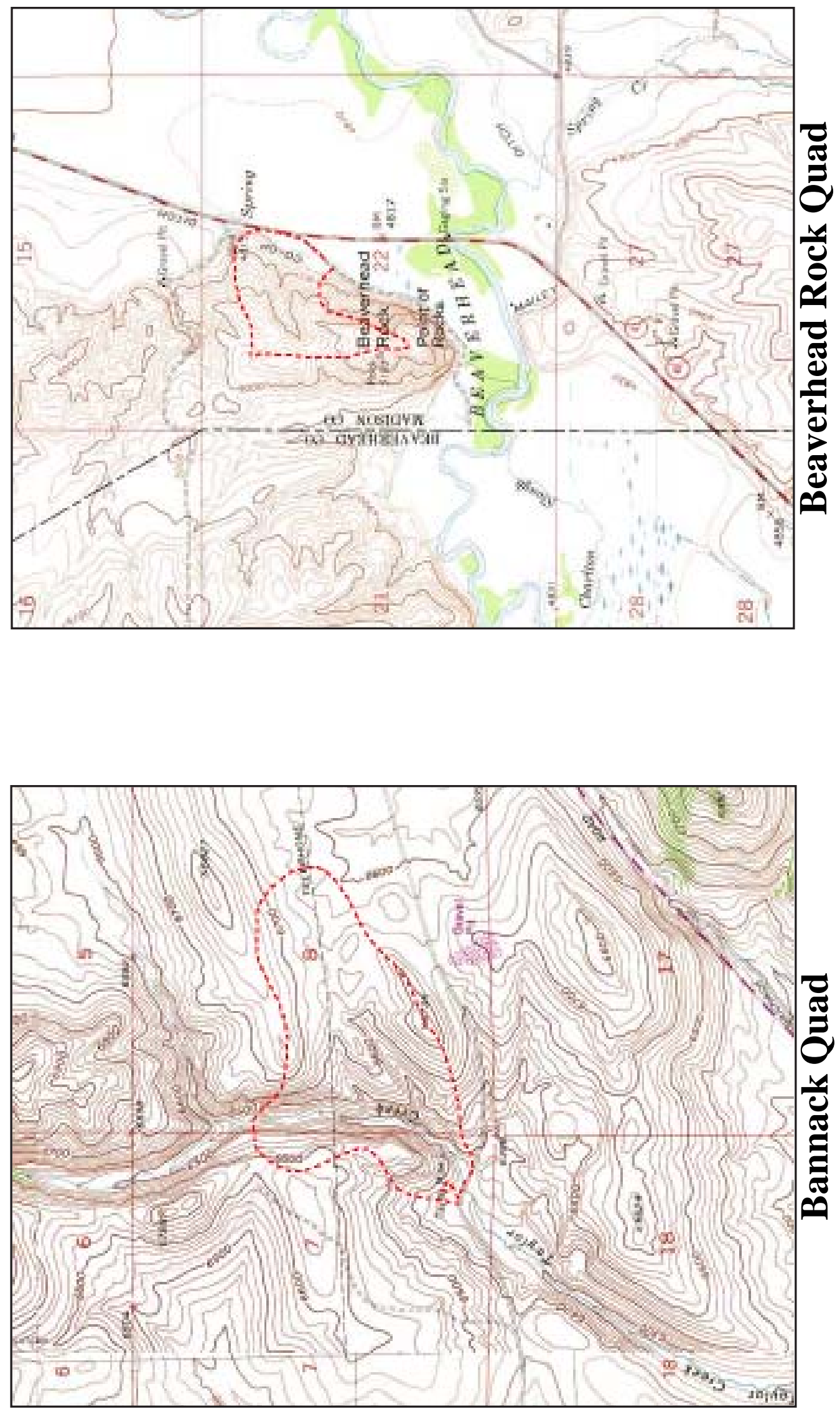

Appendix D - 2 

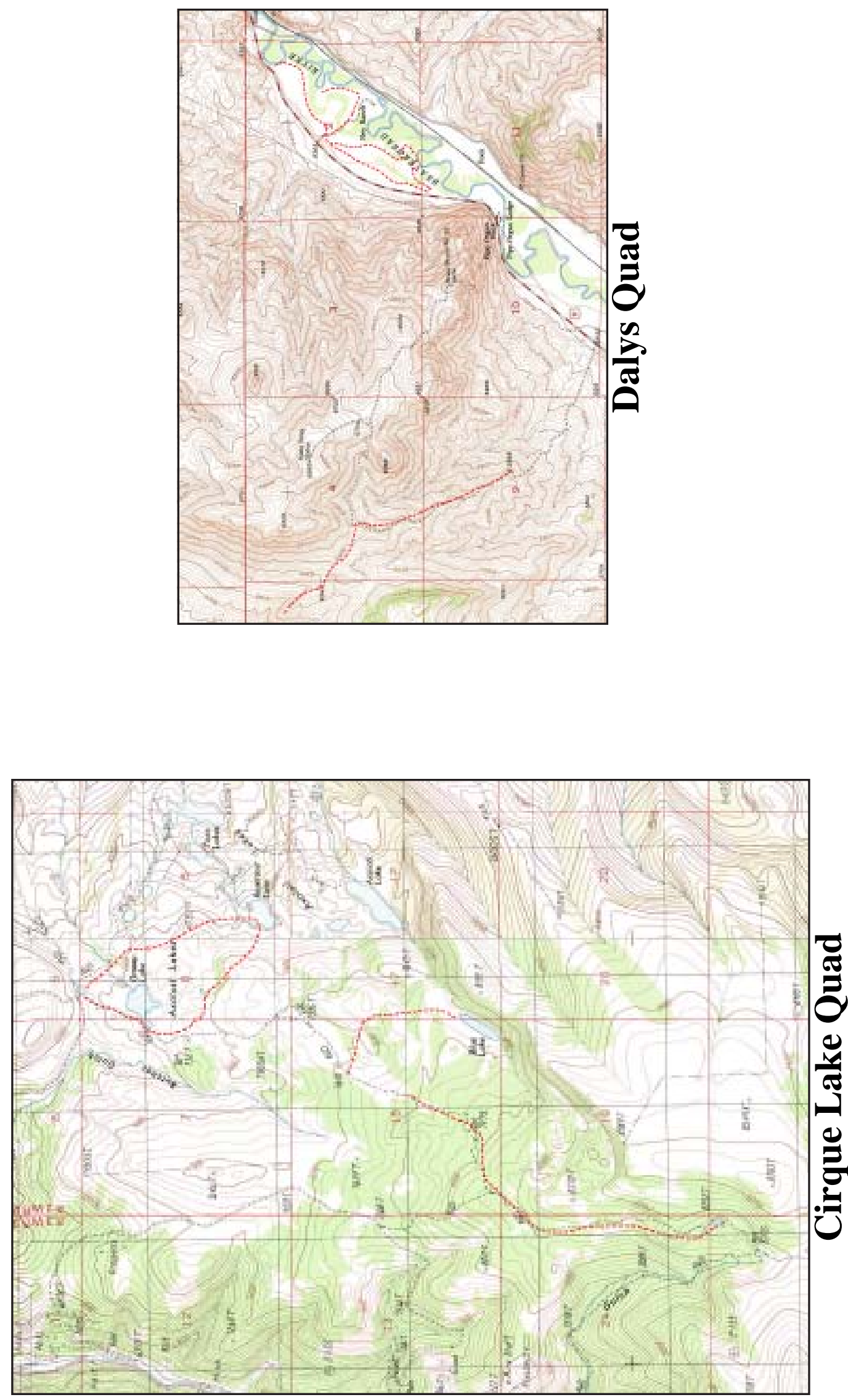

Appendix D - 3 

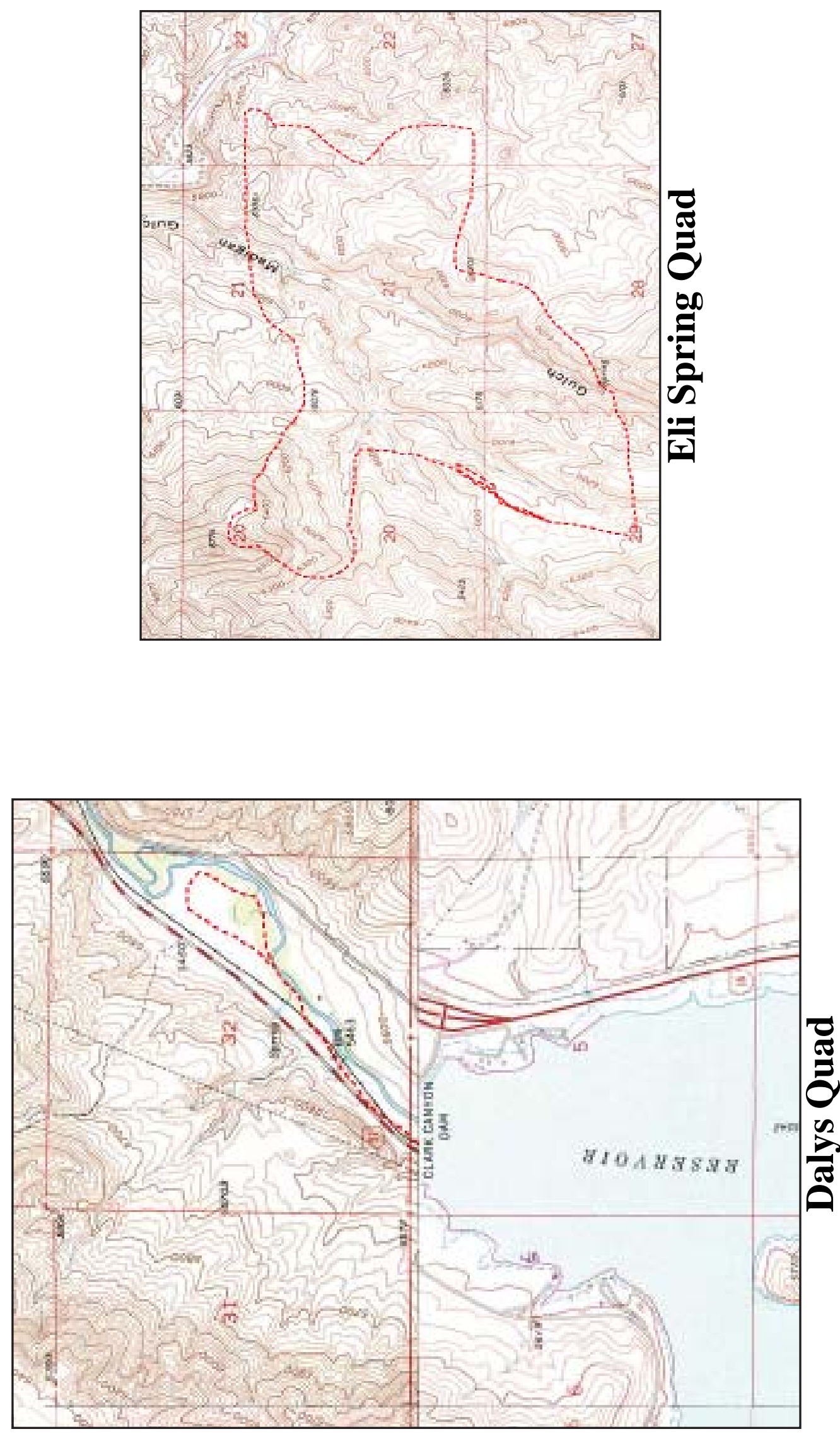

Appendix D - 4 

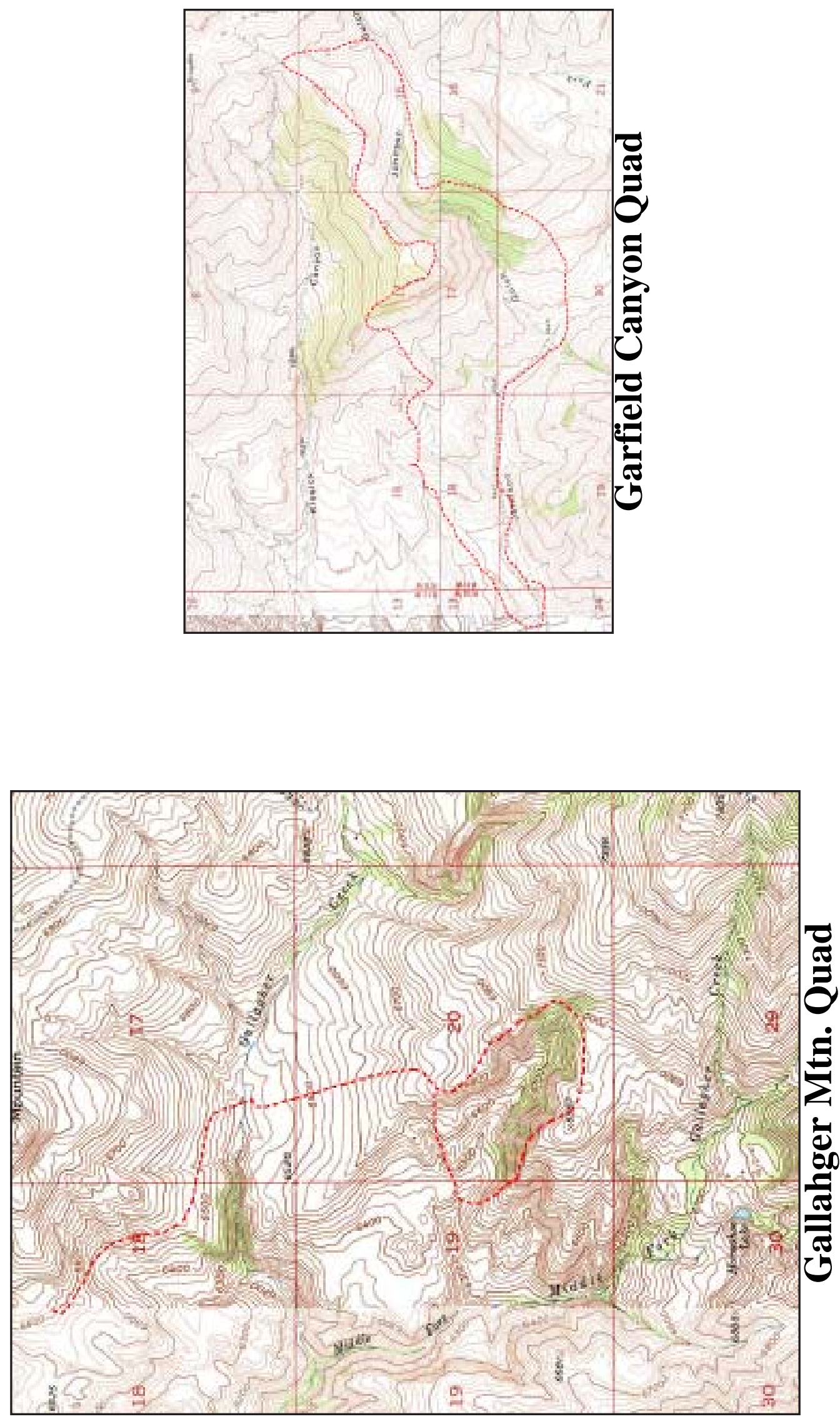

Appendix D - 5 

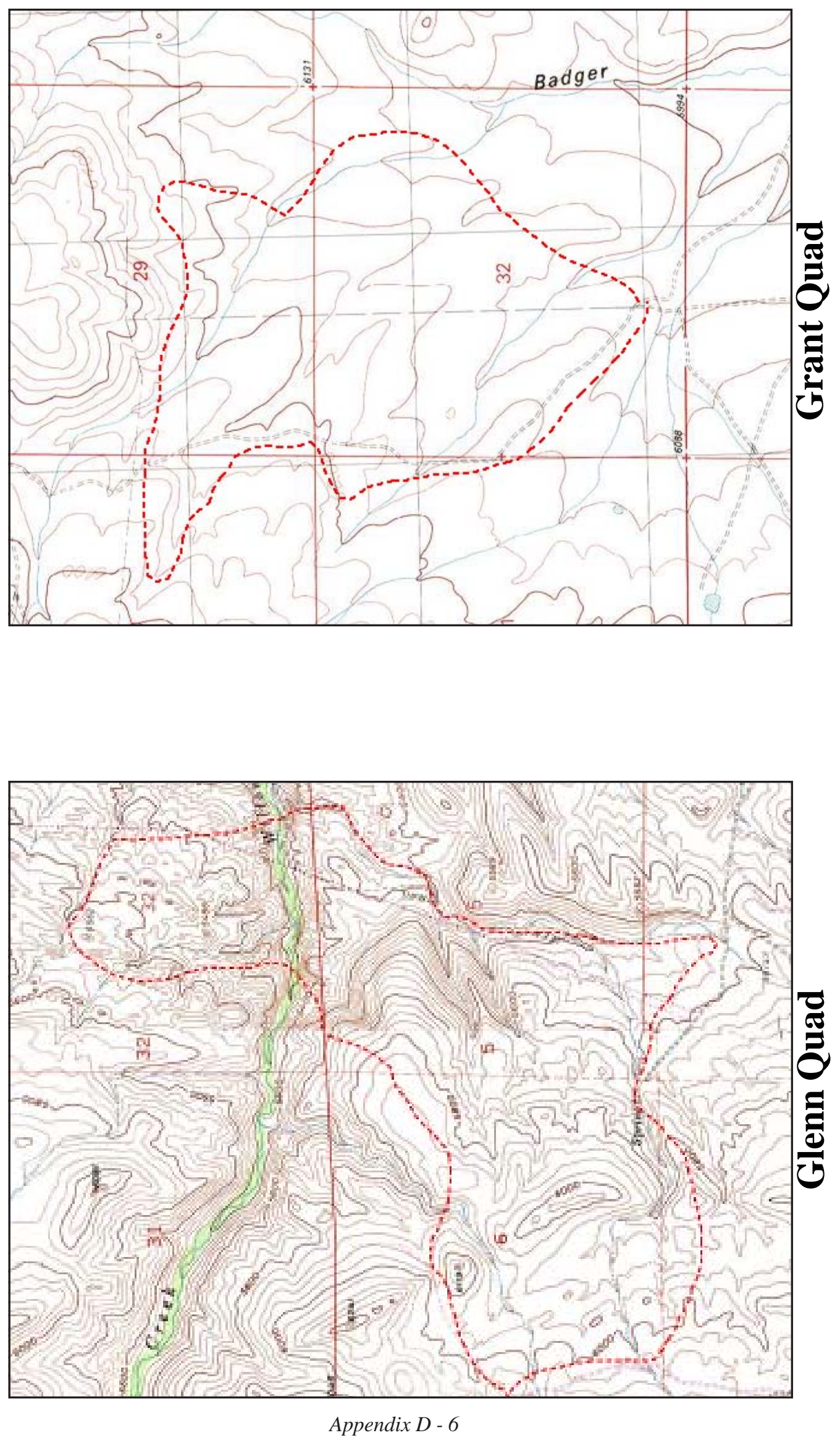

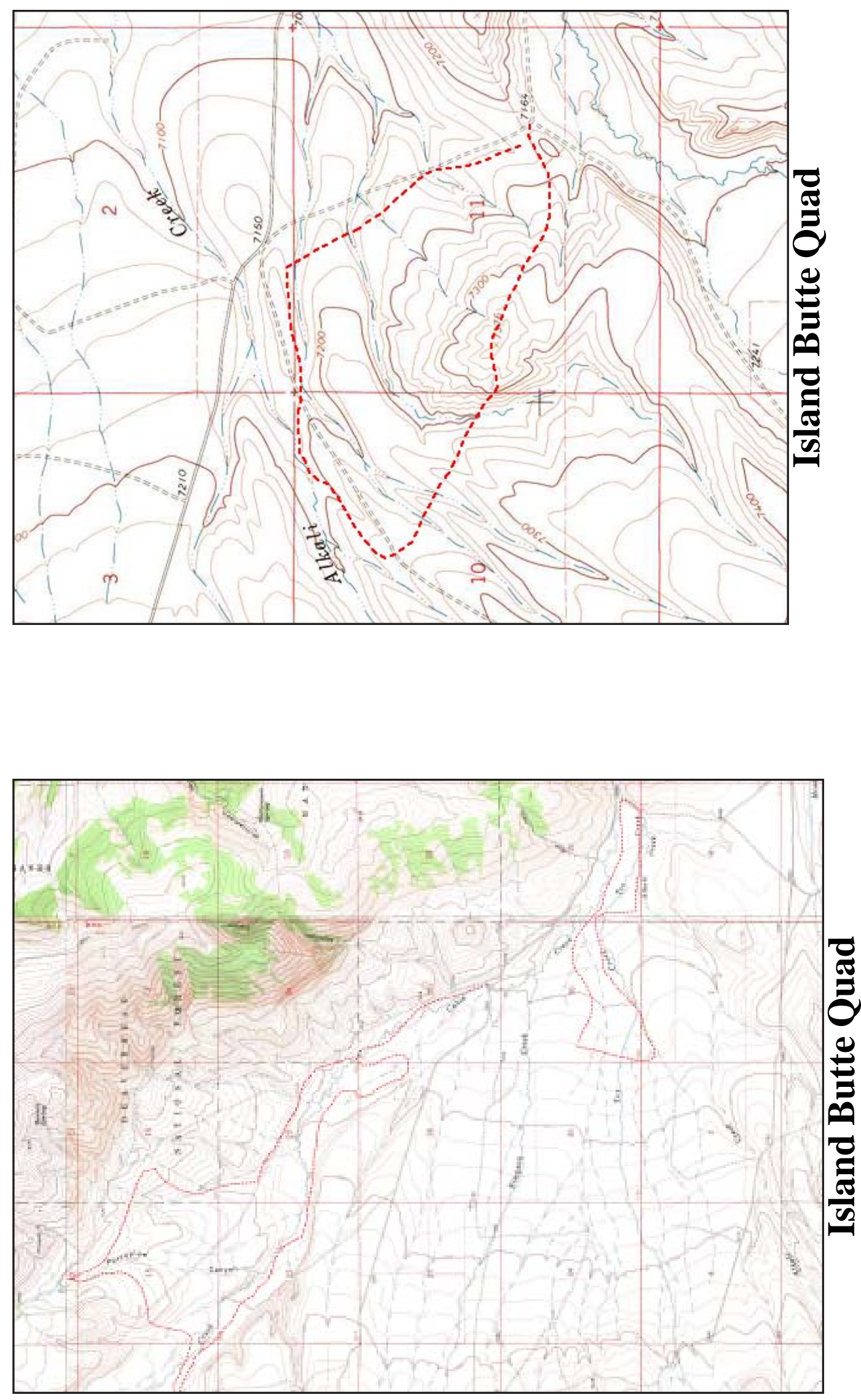

Appendix D - 7 

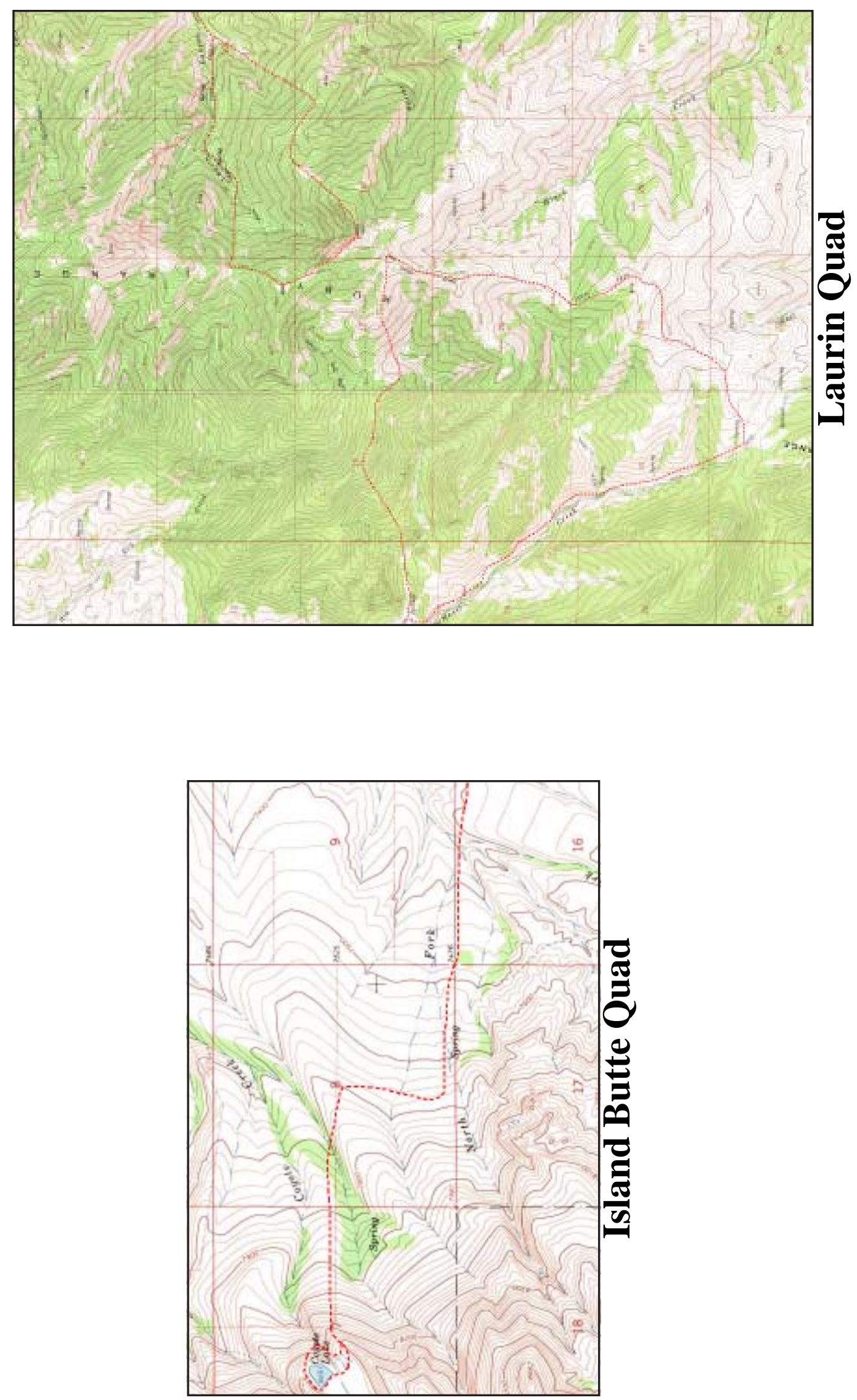

Appendix D - 8 

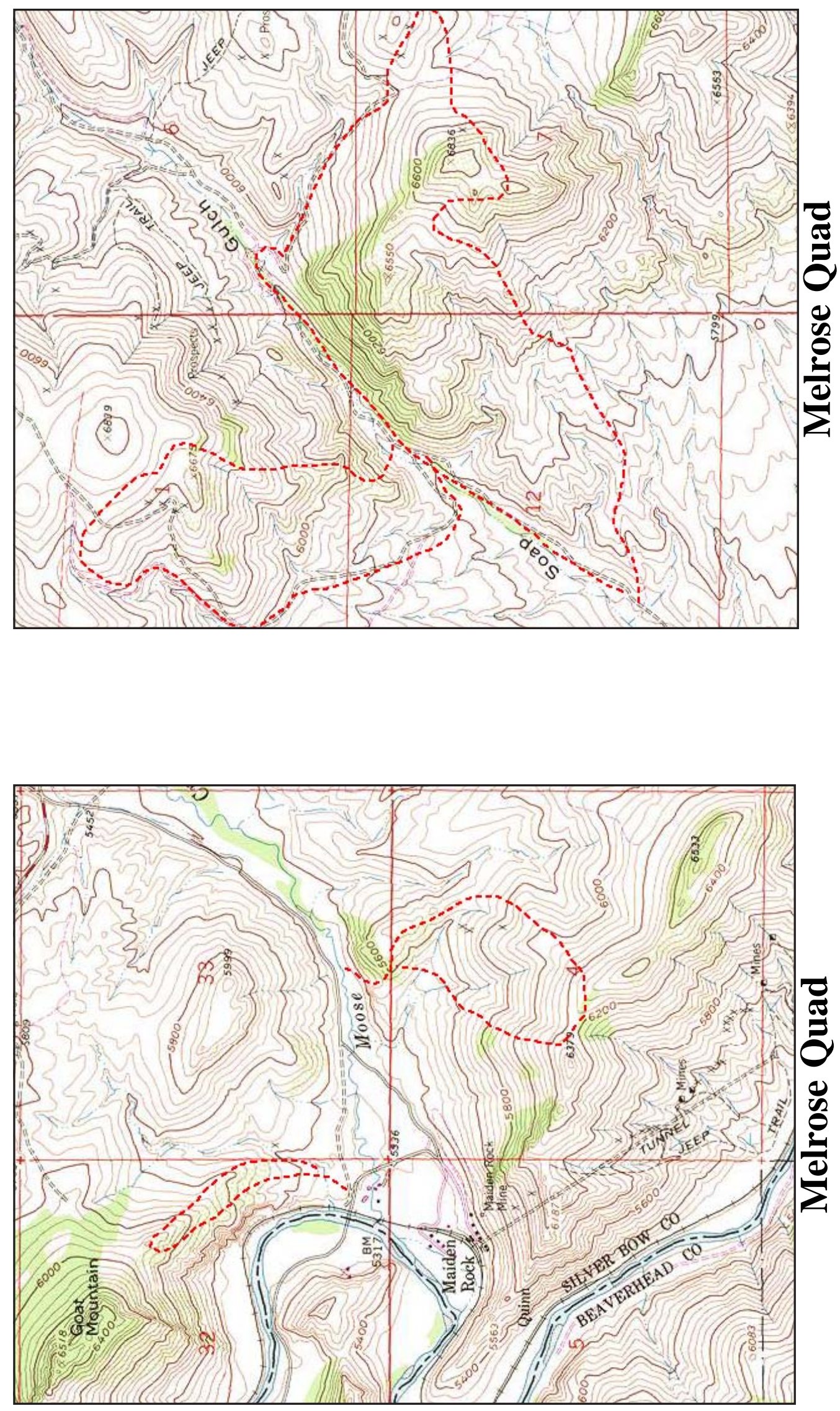

Appendix D - 9 

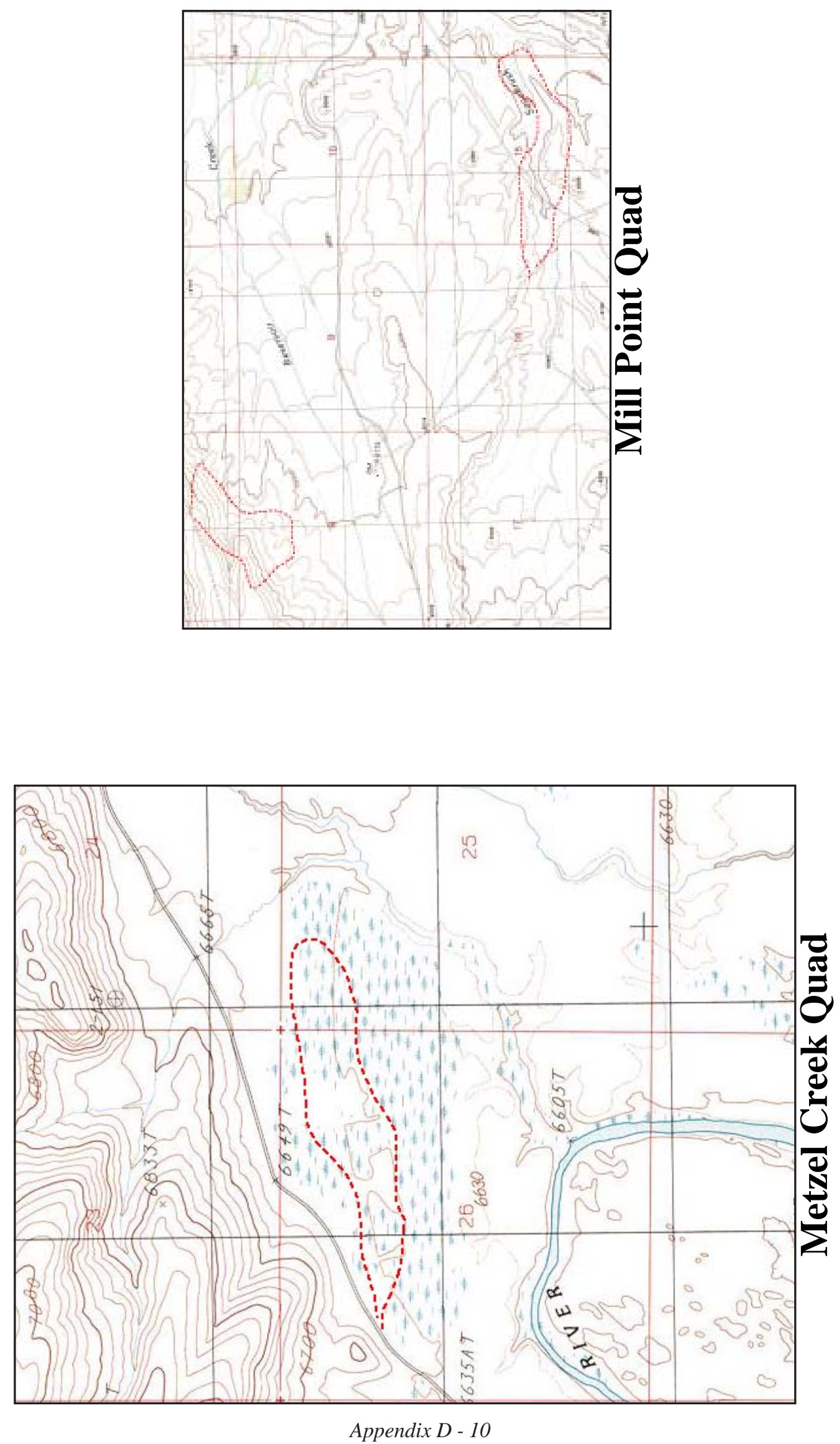

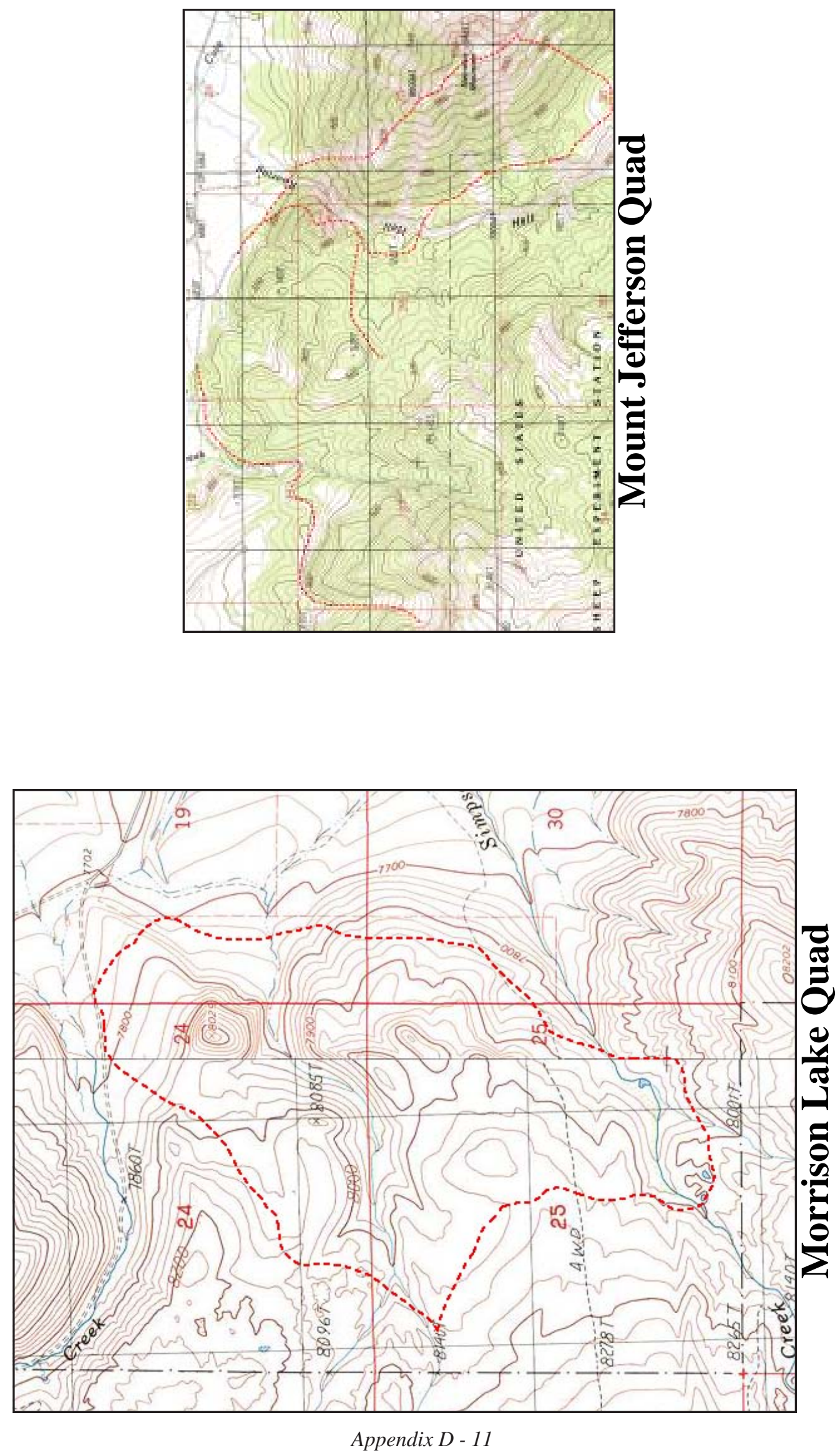

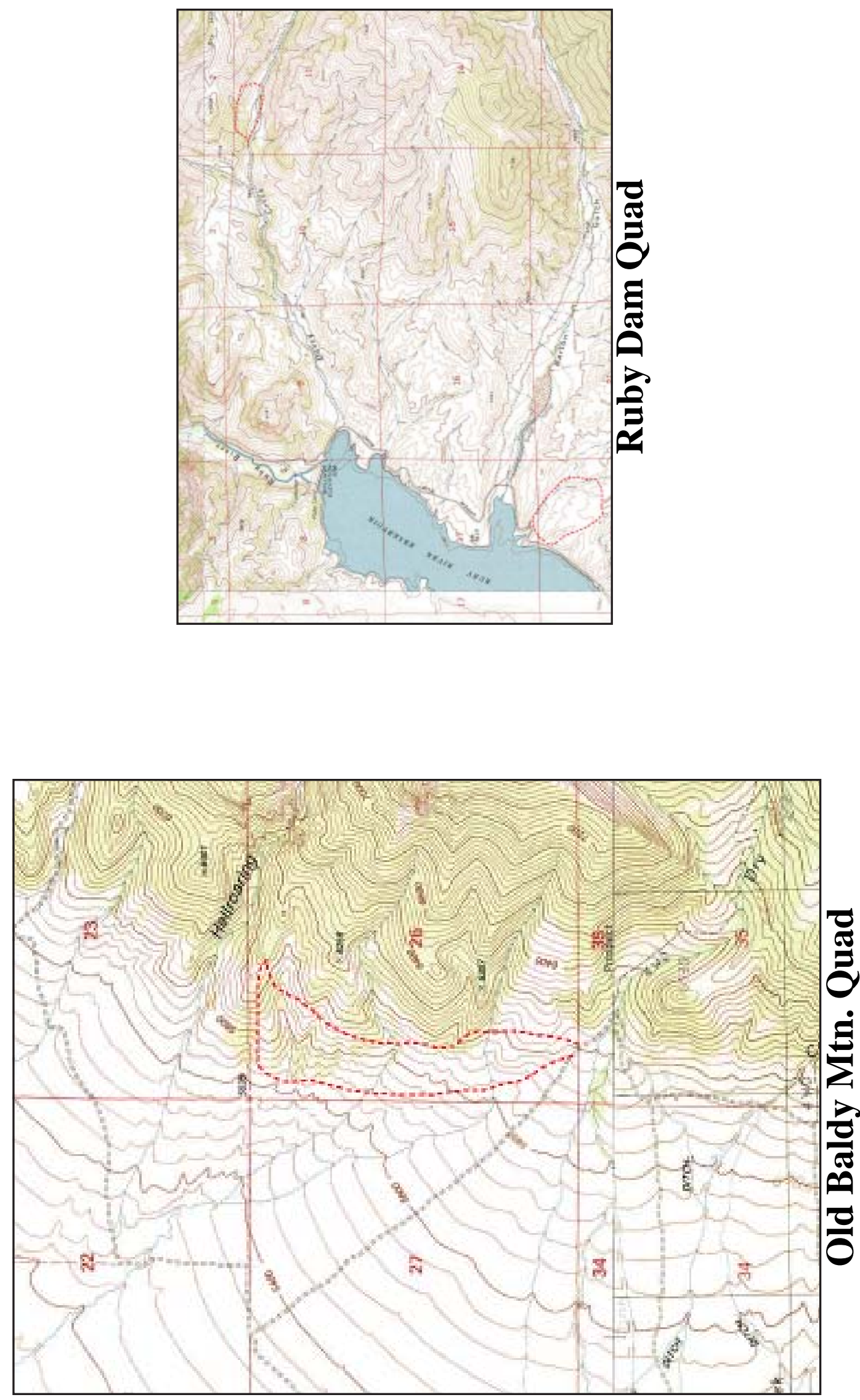

Appendix D - 12 

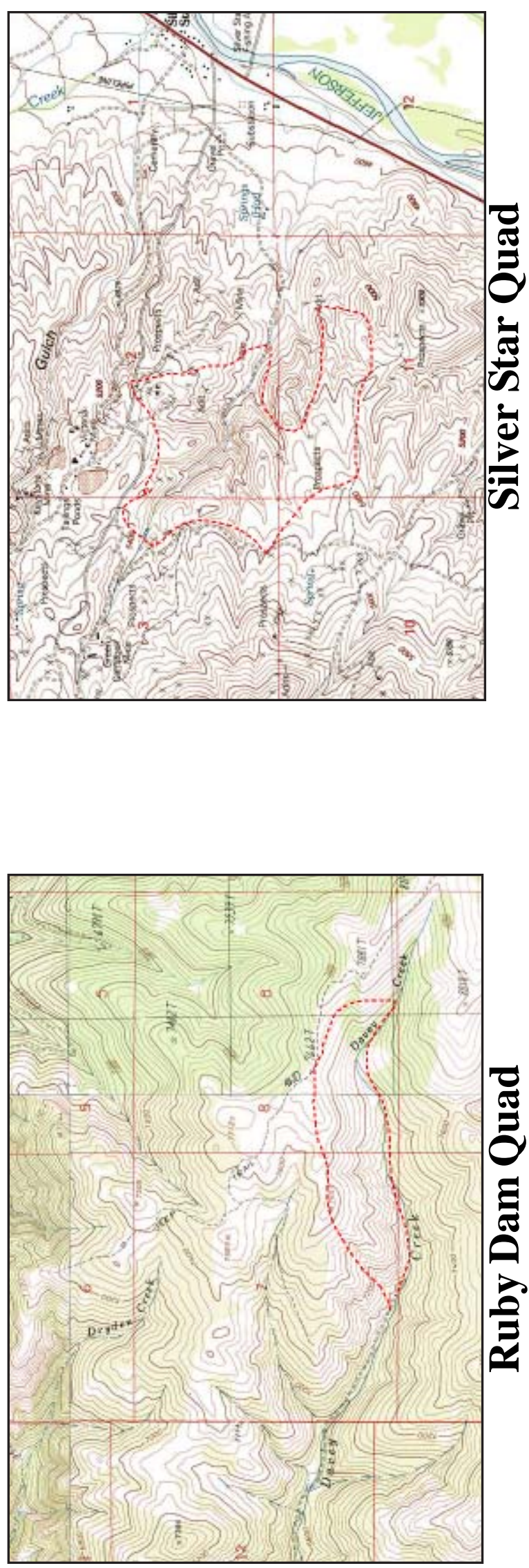

Appendix D - 13 

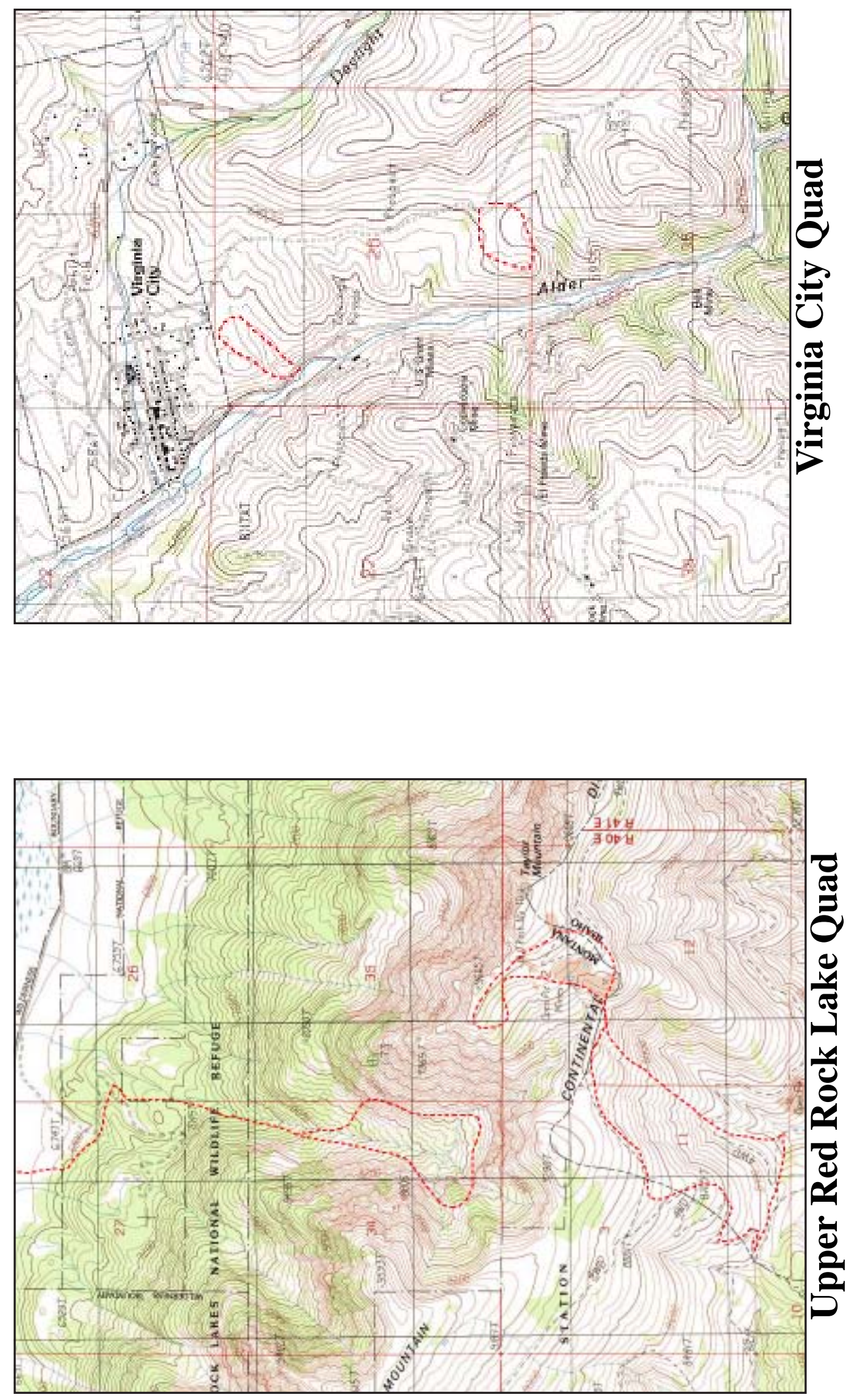

Appendix D - 14 


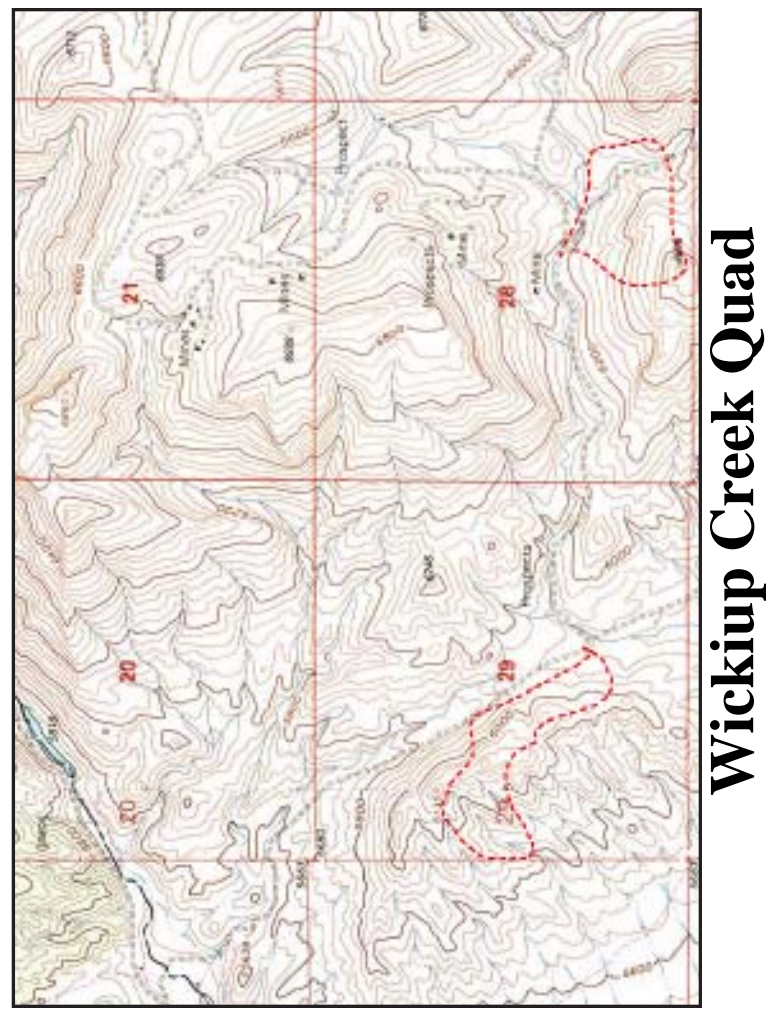

Appendix D - 15 
Appendix E. Draft manuscript on the taXonomic status of ERIGERON PARRYI 
The Resurrection of Erigeron parryi

NOVEMBER 2003 DRAFT

Peter Lesica

Herbarium, Division of Biological Sciences

University of Montana

Missoula, MT 59812

and

Montana Natural Heritage Program

1515 E. Sixth Ave

Helena, MT 59620 


\begin{abstract}
Erigeron parryi was described in 1890 from a single collection taken in southwest Montana. No additional collections were made during the following 90 years, and recent floristic treatments have synonomized E. parryi under E. ochroleucus. I used principal components and discriminant analyses of morphological characters to examine the relationship of E. parryi to its presumed closest relatives, E. ochroleucus, E. radicatus and E. scribneri, in light of several populations discovered in the past 20 years. Erigeron parryi should be considered a distinct species. It can be readily distinguished from closely related taxa based on vegetative vesture and caudex morphology. It is allopatric with E. ochroleucus and E. scribneri and ecologically separated from E. radicatus. Erigeron scribneri is intermediate between E. ochroleucus and $E$. radicatus and is probably best treated as a variety of one or the other of these species.
\end{abstract}

\title{
Introduction
}

The genus Erigeron has its primary center of diversity in the mountainous regions of western North America where local endemism is common (Cronquist 1947). The Erigeron ochroleucus complex, consisting of E. ochroleucus Nutt., E. scribneri (Canby ex Rydb.) and E. radicatus (Hook.) has its center of distribution in Montana and Wyoming. Erigeron ochroleucus is found primarily at low- to mid-elevations, while $E$. radicatus generally occurs near or above treeline. Erigeron scribneri is found at all but the lowest elevations. These three sympatric species are taprooted and have linear leaves and similar involucre indumentum but are reported to differ in size, vegetative indumentum, and caudex branching. Most recently E. scribneri has been treated as a variety of E. ochroleucus (Cronquist 1947, 1955; Dorn 2001).

Another member of the E. ochroleucus complex is Erigeron parryi Canby \& Rose. It was first collected in 1888 by Frank Tweedy in extreme southwest Montana. The label reads, "dry hills, 7,000 ft., Grasshopper Creek, Beaverhead County." Erigeron parryi was described by William Canby and Joseph Rose based on this one collection (Canby 1890). It appeared in Rydberg's flora of the Rocky Mountains and Booth and Wright's flora of Montana (Rydberg 1922, Booth and Wright 1959). However, Coulter and Nelson (1909) reduced both E. parryi and E. scribneri to synonomy under E. radicatus. Cronquist retained E. parryi in his 1947 monograph, stating:

"Except for the dense and spreading pubescence of the stem and leaves, this plant suggests a small form of E. ochroleucus. The pubescence of the involucre and all the technical characters of the head are well within the limits of variability of E. ochroleucus. It seems probable that $E$. parryi is merely an unusual form of that species, but the difference in 
appearance of the pubescence is so marked that I hesitate to make an unqualified reduction without further evidence."

However, just a few years later he did reduce E. parryi to synonomy under E. ochroleucus, stating that $E$. parryi was "a rare form with the herbage uniformly spreading hairy" (Cronquist 1955). These statements suggest to me that Cronquist was uncomfortable with maintaining a species based on a single collection made nearly seven decades before.

Several collections made in southwest Montana during the past 20 years fit the description of Erigeron parryi. The discovery of these populations warranted a re-evaluation of E. parryi. At the same time it seemed appropriate to consider the taxonomic disposition of other sympatric members of this tight-knit complex. Erigeron lackschewitzii, Nesom \& Weber is another similar species endemic to north-central Montana and most closely related to E. simplex Greene (Nesom and Weber 1983) or E. scribneri (Kerstetter 1994). I did not consider E. lackschewitzii in this study.

\section{Methods}

Plant materials- I collected data on 15 morphological characters considered important for separating the four members of the species complex (Cronquist 1947; Kerstetter 1994, personal communication; Table 1). I took measurements from one (E. radicatus) or two (E. ochroleucus and E. scribneri) collections representative of that plant in each county where it occurs. Measurements were taken from specimens representing all known E. parryi populations. When possible, I took data from the largest and smallest specimens on each herbarium sheet in order to capture the full range of variation. A total of 245 specimens were measured: E. parryi $(\mathrm{N}=22)$, E. ochroleucus $(\mathrm{N}=109)$, E. radicatus $(\mathrm{N}=28)$ and E. scribneri $(\mathrm{N}=86)$. I examined specimens from University of Montana (MONTU), Montana State University (MONT), University of Wyoming (RM), University of Idaho (ID) and Brigham Young University (BYU).

A caudex is the woody, subterranean stem surmounting the taproot. I recorded the order of branching displayed by the caudex; e.g., the branches of the caudex are themselves branched in a twice branched caudex. I also scored the degree to which the woody caudex is clothed by old leaf bases which give it a ragged appearance. An intermediate score was given to plants in which only the uppermost few mm of caudex retained leaf bases. Stem hair attitude was scored from 1 to 5 ; 1 when most hair was tightly appressed to the stem; 5 when most hair was at right angles to the stem. I assigned intermediate classes when the attitude of stem hair was a mixture. For example, a mixture of appressed and ascending hair was scored as 2 . I measured the density of hair in 2-3 $0.05 \mathrm{~mm}^{2}$ frames under a 30X microscope. Stem hair density was measured at mid stem, while leaf hair density was measured on the adaxial surface of the upper half of the largest basal leaves. 
Data analysis- I used principal components analysis (PCA) with all 15 characters to assess the degree and type of morphological divergence among taxa. Variables with loadings greater than 0.50 were considered important for determining a principal component (Manly 1986). Backward stepwise discriminant analysis (DA) was employed to determine to what extent plants could be unambiguously assigned to a taxon and which characters best separated pairs of taxa. I assigned specimens to a taxon based on determinations made by authors of previous studies (Cronquist 1947, Kerstetter 1994) when possible or by using keys in floristic and monographic studies (Cronquist 1947, Dorn 2001). The two variables with the largest loadings were retained in the final discriminant function.

\section{Results}

The first two principal components explained $44 \%$ of the variation in the 15 measured variables and achieved the best separation of the four taxa (Fig. 1, Table 1). PCA1 is clearly a size gradient. All five size characters (Table 1) and disk corolla length were important variables and were positively correlated (Table 2). PCA2 is a gradient of increasing density of leaf hair and clothing of the caudex with old leaf bases. PCA3 explained less than $10 \%$ of the variation and failed to separate any of the four taxa.

Results of the pairwise discriminant analyses are shown in Table 3. Erigeron parryi was accurately distinguished from other members of the complex ( $\geq 95 \%$ correct), and leaf hair density was the most distinct character. DA separated the other members of the complex on size characters and caudex branching. Erigeron ochroleucus and E. radicatus were accurately distinguished (98\% correct). However, E. scribneri was not well separated from either $E$. ochlorleucus or E. radicatus ( $\leq 88 \%$ correct).

Erigeron ochroleucus, E. scribneri and E. radicatus are largely sympatric in Montana and Wyoming (Fig. 2). Erigeron ochroleucus is most common at lower elevations ( $\bar{x}=1550 \mathrm{~m}$ ), while E. scribneri $(\bar{x}=2280 \mathrm{~m})$ and E. radicatus $(\bar{x}=2790 \mathrm{~m})$ occur most often at high elevations. Erigeron parryi occurs in an area of Montana where E. ochroleucus and E. scribneri have not been collected. Erigeron parryi is sympatric with E. radicatus (Fig. 2), but it occurs at midelevations $(\bar{x}=1755 \mathrm{~m})$. All four taxa are common only east of the Continental Divide.

\section{Discussion}

Erigeron parryi appears to be a species distinct from other members of the E. ochroleucus complex. As noted by Cronquist (1947), it differs in having herbage covered with dense, erect hair. This vesture is quite different from the appressed, sparse hair of the other three taxa. In addition, the caudex of $E$. parryi is regularly clothed in old leaf bases, while this trait is uncommon in the other three taxa. Erigeron parryi apparently occurs outside the range of $E$. 
ochroleucus and E. scribneri (Fig. 2). Both E. parryi and E. scribneri occur in Broadwater County, but the former was found at low elevations in the western portion of the county, while the latter was collected at high elevations in the northeastern part of the county. Erigeron parryi and $E$. radicatus are sympatric, but are well separated on an elevational gradient.

Erigeron ochroleucus and E. radicatus also seem distinct from each other. The former is a larger species, usually with four or more stem leaves, while the latter is rarely more than $3 \mathrm{~cm}$ high with fewer than four stem leaves. A branched caudex is rare in E. ochroleucus but common in E. radicatus. Erigeron radicatus often has involucre hairs with purple crosswalls, while this trait is rare in E. ochroleucus. Erigeron radicatus generally occurs at higher elevations than $E$. ochroleucus. These two taxa have usually been considered distinct species (Rydberg 1922; Cronquist 1947, 1955; Dorn 2001).

Erigeron scribneri appears intermediate between E. ochroleucus and E. radicatus and overlaps these two species in most characters (Fig. 1). Results of DA indicate that E. scribneri cannot be reliably differentiated from either of the other species using the characters measured in this study (Table 3). Erigeron scribneri was reduced to synonomy with E. radicatus by Coulter and Nelson (1909). Cronquist (1947) relegated E. scribneri to a variety of E. ochroleucus noting that the only significant characters separating two taxa were related to size, and there were many intermediates. Results of my study confirm Cronquist's observations, but it is not clear whether E. scribneri is more closely related to E. ochroleucus or E. radicatus. Cronquist (1947) believed that $E$. ochroleucus var. scribneri has more finely hairy stems and less caudex branching than $E$. radicatus, and Dorn (2001) separates the taxa on disk corolla size and number of pappus bristles. I did not measure pappus bristle number, but results from my study indicate there is a good deal of overlap between the two taxa in the other characters,. Kerstetter (1994) speculated that $E$. radicatus may be a hybrid of which $E$. scribneri is one parent. It seems best to retain Cronquist's taxonomic disposition of E. scribneri as a variety of E. ochroleucus because it is not distinct, and there is currently not enough information to demonstrate that it is more closely related to $E$. radicatus.

I present a description of Erigeron parryi because previous ones were based on a single collection:

Perennial herb with a taproot surmounted by a simple or branched, woody caudex clothed in old leaf bases; stems 2-15 cm high, densely hirsute with ascending and spreading, white hairs ca. 0.5 $\mathrm{mm}$ long; basal leaves linear, $2-5 \mathrm{~cm}$ long and $1-2 \mathrm{~mm}$ wide with vesture similar to the stem; cauline leaves 3-8, linear up to $2 \mathrm{~cm}$ long, reduced upward; heads 1-3 per stem; involucre 4-9 mm high and 8-12 mm wide pressed, sparsely glandular, villous with long and short multicellular hairs rarely with purple crosswalls; phyllaries subequal, linear-lanceolate, greenish with purple tips; ligules 20-40, white but sometimes drying pink, 5-8 mm long; disk corollas 2.5-4.0 mm long; 
pappus of 12-15capillary bristles ca. as long as the disk corolla and outer shorter bristles or squamellae; achenes ca. $2 \mathrm{~mm}$ long, sparsely to moderately hairy (Fig. 3).

Locally common in sparsely vegetated, stony, limestone-derived soil of slopes and ridge crests in the sagebrush zone (1350-2135 m) of Beaverhead, Broadwater, Jefferson and Madison counties, Montana. Flowering in June and July.

Type: United States, Montana, Beaverhead Co.; Grasshopper Creek, dry hills, 7,000 ft., July 1888, F. Tweedy 15 (NY, GH, MONT)

Representative specimens: United States, Montana, Beaverhead Co., above Grasshopper Creek, 5,500 ft., 12 June 1984, P. Lesica 2995 (MONTU); Red Butte nw of Lima, 6,200 ft., 6 July 1986, P. Lesica 3928 (MONTU); above Muddy Creek, 7,000 ft., 27 June 1987, K. Lackschewitz 11307 (MONTU); same location, 9 July 1993, P. Lesica 6063 (MONTU); 2 mi. s of Grasshopper Creek, 6,200 ft.,23 June 2003, P. Lesica 8657 (MONTU, RM). Broadwater Co., 1 mi. s of Spokane Hills, 14 May 1998, P. Vanderhorst s.n. (MONT). Jefferson Co., ne of Cardwell, 5,200 ft., 31 May 1991, Lesica 5347 (MONTU); same location, 2 June 1993, J. Vanderhorst 4899 (MONT) Vanderhorst 4899 (MONT); same location, 17 June 2003, P. Lesica 8630 (MONTU, RM). Madison Co., Trudeau Warm Spring, 5,500 ft., 10 July 1983, P. Lesica 2712 (MONT), ca. 1 mi s of Victoria Mine, 5,250 ft., 2 July 1994, P. Lesica 6345 (MONTU); same location, 21 June 1995, T. Kerstetter 3901 (MONT, MONTU); same location, 18 June 2003, P. Lesica 8640 (MONTU, RM), s of Ruby Reservoir, 5,600 ft., 28 May 1983, K. Lackschewitz 10426 (MONTU); same location, 19 June 2003, P. Lesica 8645 (MONTU).

The exact location for the type collection is not known. Erigeron parryi is common on the slopes of Grasshopper Creek below Bannack at elevations at or below $1830 \mathrm{~m}$. However, limestone is not common along Grasshopper Creek at elevations of $2135 \mathrm{~m}(7,000 \mathrm{ft})$ as reported by Tweedy. I searched several areas around Bannack and farther upstream at elevations closer to $2135 \mathrm{~m}$ but was unable to locate the plant. Perhaps Tweedy reported the wrong elevation, but this seems unlikely because he was a civil engineer by trade.

Erigeron parryi may be distinguished from its presumed closest relatives by the following key.

1a. Herbage canescent with dense, ascending or erect hairs; caudex thickened by presence of old leaf bases well below the current leaves. E. parryi

1b. Herbage green, leaf hair sparse and appressed to the surface; old leaf bases usually present only just below the leaves. 
2a. Caudex of most plants branched; basal leaf surfaces mostly glabrous; stem leaves usually 1-2. E. radicatus

2b. Caudex usually unbranched; basal leaves with sparse appressed hair; stem leaves of welldeveloped plants three or more.

3a. Stems mostly up to $6 \mathrm{~cm}$ high; stem leaves five or fewer; plants often subalpine or higher................................................................................... E. ochroleucus var. scribneri 3b. Stems of well-developed plants greater than $6 \mathrm{~cm}$ high; plants primarily of valleys and foothills. E. ochroleucus var. ochroleucus

Acknowledgements

Funding was provided by the Montana Office of the Bureau of Land Management. Tulli Kerstetter, Matt Lavin and Arnold Tiehm gave advice and encouragement. Stuart Markow (RM) and Cathy Seibert (MONT) helped me select specimens. Alan Cox helped prepare the map. I am grateful to the curators of BYU, ID and MONT for allowing use of their specimens. This paper is dedicated to the memory of Art Cronquist who helped me with many past projects. 
Literature cited

Booth, W. E. and J. C. Wright. 1959. Flora of Montana, Part II. Montana State University, Bozeman.

Canby, J. N. 1890. Notes on some western plants. Botanical Gazette 15: 63-67.

Coulter, J. M. and A. Nelson. 1909. New manual of botany of the Central Rocky Mountains. American Book Company, New York.

Cronquist, A. 1947. Revision of the North American species of Erigeron, north of Mexico. Brittonia 6: 121-302.

Cronquist, A. 1955. Vascular plants of the Pacific Northwest, Part 5: Compositae. University of Washington Press, Seattle.

Dorn, R. D. 2001. Vascular plants of Wyoming. Mountain West Publishing, Cheyenne, WY.

Kerstetter, T. A. 1995. Taxonomic investigation of Erigeron lackschewitzii. M.S. thesis, Montana State University, Bozeman.

Manly, B. F. J. 1986. Multivariate statistics. Chapman and Hall, London.

Nesom, G. L. and W. A. Weber. 1983. A new woolly-headed, monocephalous Erigeron (Asteraceae) from Montana. Madrono 30: 245-249.

Rydberg, P. A. 1922. Flora of the Rocky Mountains and adjacent plains. Hafner Publishing, New York. 
Table 1. Characters and their states used in multivariate analyses and morphological descriptions.

\section{$\underline{\text { Size }}$}

Stem height

Stem leaf number

Middle stem leaf length

Involucre height

Involucre width

Anatomy

Heads/stem

Persistent leaf bases

Caudex branching order

\section{Vegetative vesture}

Stem hair length

Stem hair attitude

Stem hair density

Leaf hair density

\section{Reproductive}

Disk corolla length

Ray color

$\%$ involucre hair with

purple crosswalls

\author{
nearest $5 \mathrm{~mm}$ \\ nearest $1 \mathrm{~mm}$ \\ nearest $0.5 \mathrm{~mm}$ \\ nearest $0.5 \mathrm{~mm}$
}

largest number

$0=$ none, $0.5=$ few, $1=$ clothes the caudex branch

$0=$ unbranched, $1=$ branched once, $2=$ twice branched etc.

nearest $0.1 \mathrm{~mm}$

$1=$ appressed, $3=$ ascending, $5=$ erect

nearest 1 per ?? $\mathrm{mm}^{2}$ field

nearest 1 per ?? $\mathrm{mm}^{2}$ field

nearest $0.1 \mathrm{~mm}$

$1=$ white, $2=$ pink, $3=$ purple

$0=$ none, $1=1 \%, 2=2-10 \%, 3=>10 \%$ 
Table 2. Results of principal components analysis. Important factor loadings $(>0.5)$ are in bold.

$\begin{array}{lrrr} & \text { PCA1 } & \text { PCA2 } & \text { PCA3 } \\ & & & \\ \text { Variation explained } & 30.4 \% & 13.0 \% & 9.2 \% \\ & & & \\ \text { Stem height } & \mathbf{- 0 . 8 6 1} & 0.201 & -0.186 \\ \text { Stem leaf number } & \mathbf{- 0 . 8 1 5} & 0.178 & -0.094 \\ \text { Stem leaf length } & \mathbf{- 0 . 7 7 6} & 0.144 & -0.047 \\ \text { Involucre height } & \mathbf{- 0 . 6 2 8} & -0.056 & 0.110 \\ \text { Involucre width } & \mathbf{- 0 . 7 3 6} & -0.106 & 0.332 \\ \text { Heads/stem } & -0.327 & 0.499 & -0.122 \\ \text { Persistent leaf bases } & 0.355 & \mathbf{0 . 6 1 9} & 0.208 \\ \text { Caudex branching } & 0.456 & 0.071 & -0.110 \\ \text { Stem hair length } & 0.164 & 0.094 & -0.377 \\ \text { Stem hair attitude } & \mathbf{0 . 7 0 0} & 0.398 & 0.053 \\ \text { Stem hair density } & 0.292 & 0.129 & \mathbf{0 . 5 6 7} \\ \text { Leaf hair density } & 0.259 & \mathbf{0 . 7 5 1} & 0.302 \\ \text { Disk corolla length } & \mathbf{- 0 . 5 9 1} & 0.087 & \mathbf{0 . 5 2 7} \\ \text { Ray color } & 0.031 & -0.391 & \mathbf{0 . 5 3 5} \\ \text { Purple crosswalls } & 0.409 & \mathbf{- 0 . 5 8 1} & 0.137\end{array}$

Table 3. Important characters separating pairs of taxa as determined by stepwise discriminant analysis. A jacknife procedure was used to estimate the proportion of plants correctly classified for each pair.

Species pairs

ochroleucus vs scribneri

radicatus vs scribneri

ochroleucus vs radicatus

parryi vs ochroleucus

parryi vs radicatus

parryi vs scribneri
Important characters

stem height, leaf number

involucre height, caudex branching

leaf number, caudex branching

leaf hair density, stem hair attitude

leaf hair density, disk corolla length

leaf hair density, number of heads
Correctly classified
$88 \%$
$78 \%$
$98 \%$
$95 \%$
$100 \%$
$97 \%$ 
Figure 1. Principal components analysis of four Erigeron taxa based on 15 morphological characters (see Table 2). Ellipses enclose scores within 1 standard deviation of the centroid for each taxon. Plants representing the isotype of E. parryi are indicated.

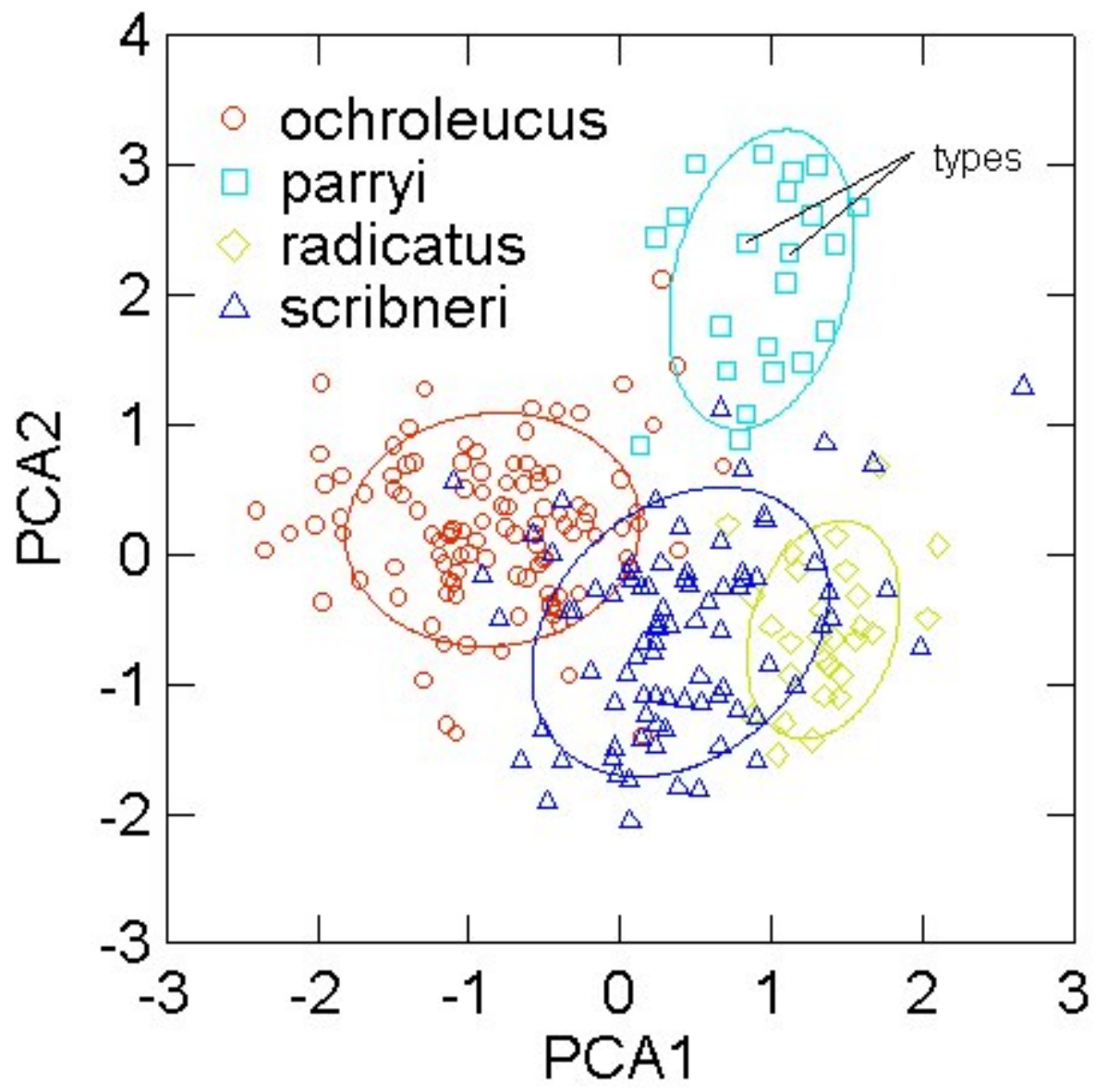




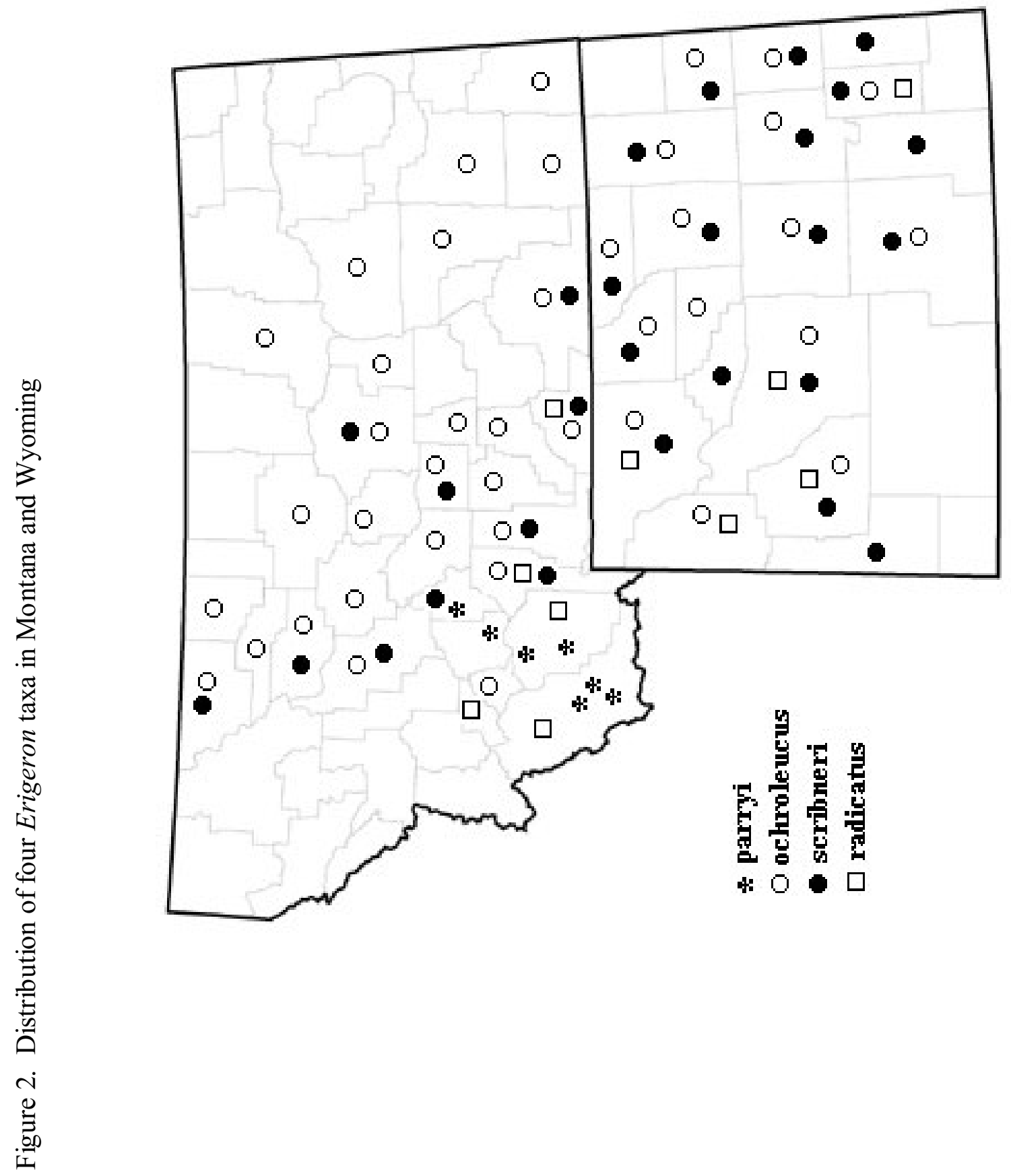

